\title{
SHAKESPEAREAN REPRESENTATION
}




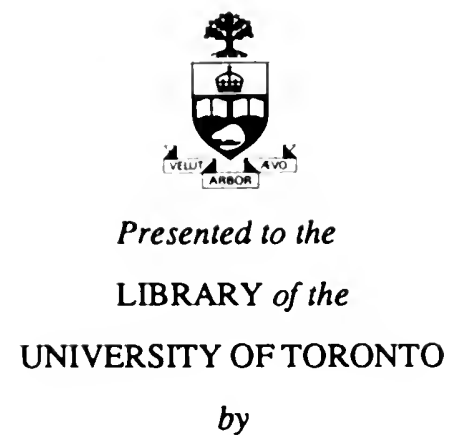

Sidney Fisher 


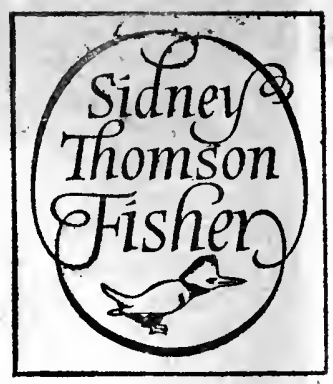


SHAKESPEAREAN REPRESENTATION 


\title{
SHAKESPEAREAN REPRESENTATION
}

\section{ITS LAWS AND LIMITS}

\author{
BY \\ PERCY FITZGERALD, M.A., F.S.A.
}

- Piece out our imperfections with your thoughts ; . . .

And make imaginary puissance ;

Think, when we talk of horses, that you see them; . . .

For 'tis your thoughts that now must deck our kings.'

'Henry V.' : Prologue

8

LONDON

ELLIOT STOCK, 62, PATERNOSTER ROW, E.C. I908 


\section{WORKS ON THE STAGE}

\section{BY THE SAME WRITER}

THE LIFE OF GARRICK

LIVES OF THE KEMBLES

LIVES OF THE SHERIDANS

PRINCIPLES OF COMEDY

ART OF THE STAGE: LECTORE AT IHE ROYAL INSTITOTION

ROMANCE OF THE ENGLISH STAGE NEW HISTORY OF THE ENGLISH STAGE LIFE OF SIR H. IRVING. (3rd Edition) THEATRICAL ANECDOTES WATTS PHILLIPS : A LIFE ADVENTURES OF A. DUMAS VANDERDECKEN. (WITH W. G. WILLS) THE WORLD BEHIND THE SCENES

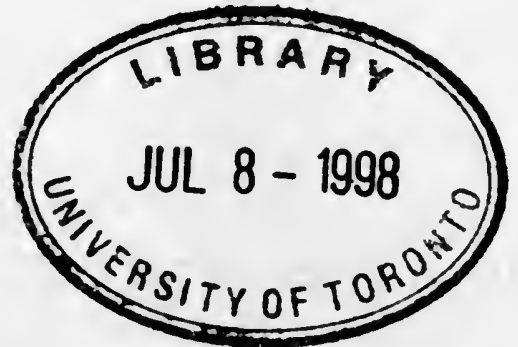




\section{PREFACE}

THE following speculations on what is a deeply interesting subject have engrossed many years' thought and careful study. It will be noted that they help to form a consistent theory. That I have some claim to speak on the subject will be seen from the long list of works upon the stage and stagelife which I have written during the past forty years or so. I have also 'served' as a dramatic critic, and have written for the stage.

At the same time I will admit that many things will be found here which seem overcharged and stated too strongly. There are general statements of abuses which might be accounted as particular. But the would-be reformer is always inclined to this failing, and the practised reader is accustomed to 'discount' all such sweeping utterances. This refers particularly to what I have said of acting, and of the system followed on our 'boards.' We have actors and actresses who act according to the most intelligent instincts and principles; but this cannot be extended to the bulk of the profession, who have a special standard of their own.

Mr. Sidney Lee, in a recent thoughtful work, has also dealt with this matter of modern Shakespearean representation, though not after the minute fashion that I have done. 



\section{CONTENTS}

CHAPTER

PAGE

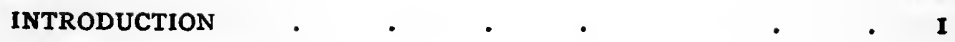

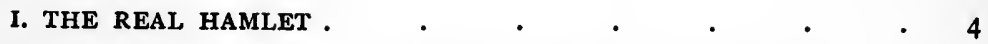

I1. SHAKESPEAREAN GHOSTS, APPARITIONS, WITCHES, ETC. 34

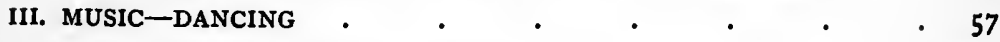

IV. MODERN REVIVALISTS-IRVING . $\quad . \quad$. $\quad . \quad 63$

V. OTHER MODERN REVIVALS . $\quad$ - $\quad$ • $\quad$ e $\quad 82$

VI. SHAKESPEAREAN BUSINESS': ITS NEGLECT AND THE REMEDV 91

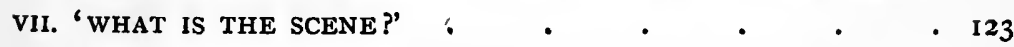

VIII. ACTING, SOLILOQUIES, ASIDES, BY-PLAY, RECITATION, ETC. I30 



\section{SHAKESPEAREAN REPRESENTATIONS}

\section{INTRODUCTORY}

$T \mathrm{~T}$ is gratifying in these modern days to note the revived interest in Shakespearean performances, which for some thirty years and more have been set forth with unbounded luxury and magnificence. A series of pageants and panoramas have passed before our eyes: huge structures solidly built, cathedrals, streets, glorious gardens, processions, armies, have dazzled or bewildered our yokel senses. The muses of Waring and Gillow or Maple have been evoked, and dozens of dressmakers have combined to lend their service. The result is a beautiful and interesting show, which recreates and entertains even the more thoughtful.

When a manager or actor-manager takes one of these pieces in hand for revival, he is bound to search carefully through the play for fresh and startling openings for decoration and marginal effects. He must, in vulgar phrase, 'go one better.' Then, he almost invariably rearranges, transposes, and combines scenes, introduces passages hitherto left out, and leaves out what has been hitherto retained. Something novel and surprising must be evolved. Money, lighting, painting, dresses, music, dancing-nothing is spared. The framework of the piece groans and totters under the superincumbent weight. In any case, the delicate allusions, the involved thought, the graces and passions and feelings, must be submerged. It is a law that the senses and the intelligence have contending interests. Excessive splendour and decoration, absorbing and dazzling the eye, distract at the same time and 
enfeeble the intelligence, just as we might imagine an impassioned speaker impeded and fettered in his utterance were he overwhelmed by the weight of rich and gaudy clothes. It is curious that words and sentences coming from the centre of a glare of light and colour seem to lose all strength of sound and emphasis. The thoughts and sentiments are poor in contrast to the gorgeous surroundings, and take the second place.

It is curious also that even this excess of decoration and stage mechanism, granting the necessity of its use as a concession to public taste, is even scarcely regulated by thoughtful principles and arrangements. The usual contrivances are crudely carried out according to old stage conventions. There is no attempt to study the particular situation from a Shakespearean point of view, so as to see what was intended, and carry it out in the most perfect way. There is a vast deal of undeveloped effects passed over and wholly lost from want of careful study. It seems to me that all the mechanical attempts at illusion are clumsily though magnificently carried out.*

It has been again and again pointed out by Mr. Sidney Lee and others that there is no attempt to equalize the characters, and thus present a perfect all-round performance, as is found in the German theatres. This, again, is the result of the exaggerated decoration, which compels, owing to considerations of time and space, the inferior players to become mere pawns in the show, passing hurriedly through the light, their words being abridged or scamped.

This sacrifice has led to the deification of the star performer, who in certain titular plays requires, if he would do himself full justice, to have the stage more or less clear; save, of course,

* In that interesting and highly popular melodrama, 'A Message from Mars,' in which Mr. Hawtrey was so successful, was shown the crudest and most primitive treatment of the supernatural, and which was accepted as quite sufficient. The visitant descended from Mars, being let down rapidly by a stout rope! Later on, when the hero was shown a 'vision' of a happy home, the simple method was adopted of drawing aside a canvas screen, when a sort of alcove was revealed, within which were huddled together a number of persons seated at a dinner-table, feasting or talking. Here was practical matter-of-fact treatment, the rest being left to the imagina- 
during this exhibition of the raree-shows. This entails wholesale abridgment, profuse cutting down and cutting out, so as to centralize the interest. No doubt, under the circumstances, this is welcome enough and often interesting. Better to have some Shakespeare, however disguised, than no Shakespeare at all. But it is far, very far from the ideal Shakespeare. 


\section{CHAPTER I}

\section{THE REAL HAMLET}

T AM disposed to begin this inquiry by showing, as a typical instance, what has been done in this way with Hamlet, which has been deliberately, though gradually, fashioned into a onecharacter piece. No one could imagine that it is a really large and crowded canvas, with a number of palpitating and interesting figures, a drama of general interest, and not a sort of biography of a single person. Yet no one ever thinks of the Danish Prince but as one solitary overpowering figure, round whom circle some dimly-illumined satellites; these, too, altered and curtailed so as to afford comic or serious relief.

One is astonished to find what vast and spreading interests it offers, and how these maimed characters really help to set off the great central figure and increase its attraction. These figures are the King, the Queen, old Polonius, Ophelia, the Ghost-all varied, full-bodied characters, not mere understrappers of Hamlet, but carrying on a drama among themselves. The stage-managers have made the King a sort of unmeaning cardboard figure, a patient foil for his nephew, instead of being an intriguing, crafty fellow, timorous yet bold, fighting hard for his own hand; the Queen, a commonplace, weak-kneed creature, instead of an active ally of her husband; and, above all, Polonius, instead of being held forth as a sort of harmless clown and the butt of everybody, a clever old schemer, perpetually at work to forward the King's plots and advance his own family.

Who has not wondered at the ease with which Hamlet baffled the designs of these poor, feeble creatures-it seemed like child's play, and they like puppets-without thinking that all their plots and machinations have been altered or suppressed to give prominence to Hamlet's ? For it is obvious that the more serious 
the dangers there were about him and the more active his enemies, the more our sympathies would be increased. With the true original drama we felt that there was before us a deadly Court struggle, in which murder, intrigue, plottings were all busily concerned.

If it be said that the extension or restoration of the original text commends itself, and is of manifest advantage, the question arises, Can it be done? Could we expect the audience to sit it all out? I am afraid this would be impossible. It has been tried by some and found to fail. It should be remembered, however, that these were mere sudden experiments, attempted without due and elaborate preparation, and not under fair conditions. But, still, it can be done by adhering to this rule and maxim: 'Abridgment, but not suppression'-that is, passages are to be shortened, not cut out; dialogues are to be pruned; repetition of the sense or meaning left out; lines and sentences that seem superfluous or have been repeated, omitted. But on the whole, abridgment, as I have said, should be the word. But to this task should be brought rare gifts and study, much tact and good sense.

It may be said that none of us have ever seen the true Hamlet performed, though we have had some crude and rather dreary attempts at setting out the whole play before us. What has been exhibited to us for generations has been a hashed-up selection of the more telling portions of the play. How few know, for instance, that the King had arranged for the assassination of his stepson long before the last attempt in the fencing scene, or that this last was planned in desperation because the first attempt had failed! Few, again, know of Hamlet's attempts to conceal Polonius's body-a symptom of madness. But, no; these things are counted excrescences and in the way. We must have the one dramatic figure- ' Ma femme et cinq poupées.'

It would not be difficult to furnish a pure and correctly classical performance of one of Shakespeare's plays which should be in perfect harmony with the poetry and characters. Still, it must be admitted that the obstacles in the way of reforming managers are enormous and wellnigh insuperable. The old hidebound traditions and practices of the stage and the debased taste of the audiences oppose. Until it is accepted that the large and generic word 'the stage' stands 
only for what it literally means-that is, is merely a raised erection to make prominent those who are interpreting some exciting picture of human character-we cannot look for any respectable performances of Shakespeare. En attendant, however, there may be efforts of a negative sort-the abolition of what should not be, even if what should be cannot be secured. Just as in the restoration of some fair old church much is gained if there is reserve used, and the existing features are simply repaired or strengthened. In the present system there are no laws or limits whatever. It is all 'happy-go-lucky.' The manager-rather, the manager-actor-'rough-hews' the bard as he may, does what he likes with the scenes, adds and superadds whatever he thinks will 'set off' the play most, and put it in touch with the present day.

But I can fancy our modern stage-manager saying: ' $M y$ dear sir, all this is truly Utopian. It may be a very excellent arrangement, but the thing would be as long as one of the Ring operas, and take, say, six hours. You would clear the house. We must get on. "Come to the 'osses "-come to business.' This is true and practical enough; but this treatment should be not 'cutting' - that is, omitting-but compression. There should be a process of compression that will retain everything, but in an abridged form. An idea, for instance, takes some forty or fifty lines; it should be skilfully compressed into half a dozen. Every incident should be there, though any amount of words may be sacrificed. This, or something of the kind, is the true principle. We may speculate how the enormous length of scenes, dialogues, speeches, etc., was dealt with in the early days. The great writer must surely have thought and intended that all he set down should be presented, for he would not have designed that so much of it should go to waste. The truth was that audiences were well accustomed to length in all things, and were schooled to follow the slow and gradual development of character. There was plenty of leisure then, and interest was excited by good declamation, which brought out the meaning of each line. Now it is rarely that we hear a passage given so as to be intelligible. In the old Covenanter times the congregation could listen with relish to sermons hours long, and without their attention flagging; so it must have been with the speeches on the stage. Even 
nowadays the French can tolerate the rather long-winded declamation of Racine and Corneille. But it all comes round to this: Any amount of Shakespeare will be acceptable and followed if it be given with skill, intelligence, due emphasis, melodious accents, sympathy, and force. As these elements are not present, we must perforce cut away all such passages as so much ' top hamper.' Further, as folks are waiting impatiently for the processions, tableaux, etc., the long speeches are so much delay, and must be cut out.

Again, it is always understood that to present Hamlet properly and according to tradition we must adopt a sort of stilted, pedantic system of elocution and bearing. We must recite, declaim, growl, or vociferate, and stride about. All such things would disappear if the players could only persuade themselves that they were ordinary men and women concerned in a terrible and momentous tragedy - if they would but put emotion and passion and warmth and nature into all they say and do. Some of Hamlet's soliloquies are of great length, but no one complains, because they are so interesting, and the powerful efforts of the actor make them more interesting still. But it is not the length nor the obscurity that is in fault; it is the lack of intelligence, training, and understanding in the recitation. Most of our players have little training in elocution, little emphasis or contrast. Milton himself, in such hands, would be ineffective. The system suggests the clerk in 'Pickwick, who was reading out the affidavits, running words into each other- ' sohelpyou God. You must get change.' And, indeed, who has ever heard a sentence of Shakespeare delivered so as to bring out the full, entire meaning? And rarely have we heard it illustrated by natural and appropriate feeling or passion; and finally, so as to leave a satisfactory impression. Still more rarely have we heard every word of the sentence. On the contrary, the meaning is too often distorted by the ignorance of the reciter, who cannot reach to it, or fails by his helplessness to give it expression. The result is that all is dark and incomprehensible to the spectator. How many a time have we listened to some Lord or Cardinal reeling off a discourse, say a hundred lines long, and which it was literally impossible to follow, or find out what he meant! I suppose there is no such prodigy of long-wordedness as Molière's 
Le Misanthrope, with its interminable speeches and dialogues. You can hardly read it, but you can study it. It seems intolerable, but in the hands of the Français company how illuminated it is! Everything that is said is heard, understood, and said in the best way possible. So intelligent is the expression given to each sentence that you are perforce attracted and led on to the next.

There has never, or rarely, been sufficient thought given to the opening scenes of Hamlet, which take place on 'the platform before the Castle,' and, later on, at 'a more remote part of the platform ' - the platform being the terrace on which cannon are placed. One can hardly imagine anything more poetical or favourable to ghostly feeling - the gloomy waste of stone wall stretching away, the parapet, the shadowy towers beyond, the blue haze as dawn draws near, the peculiar faint tinkle of the clock in the town beyond or in the courtyard of the fortress. There might be a cold moonlight, so as to cast the shadows of figures on the terrace. This terrace, too, should be a long stretch or promenade, and a lonely one. And here is usually the mistake-that there is little attention paid to the scale of things, it being attempted to squeeze into the small area all the substantial portions of a castle. This quite dispels illusion. The ghost might be seen coming down for a long distance, first afar off, then drawing near slowly and gradually, and unseen by the officers. But how much of the effect is due, not to such things, but to the ghostly character of the situation, and to the ghostly impression on the actors!

Let us take the opening passage-the relief of the guard, so mysterious and awesome in the reading, and upon which so much depends in the preparation. But who that has seen it has ever found it properly interpreted, or in any way but the most literal, matter-of-fact, and prosaic fashion? The players, generally fifth- or sixth-rate persons, seem to take for their models the common sentries they have seen relieving guard, and bark out their calls and replies in their blunt style. 'Stand!' 'Unfold yourself!' 'Long live the King!' Francisco and Bernardo are all one to them, so is the question and answer, the doubt and assurance. It is merely one soldier taking the place of the other. And yet how much more could 
be made of the situation!, what graduated mystery and sense of some expected horror could be conveyed in every word, so as to lead up to the one image that was in the minds of all!

The whole of the scene that follows is foreshadowed. Fran: cisco is pacing ' on his post'-dreaming, it may be-then, roused by the sound of the steps, Bernardo challenges the other, fancying that he himself is on duty! The factionary naturally says: 'Nay, answer me; stand,' etc. Now, what a début is here, and how effectively it could be worked! The guard, weary and expectant, the slow approach, the starts of both, the looking round of Bernardo in alarm. This conveys that both were full of the ghost, dreading its return, quite unmanned and upset, as it were. They had not got over the visitation. What real acting there could be, and how different from the mere give-and-take replies! Francisco, glad to get away and not in the secret, compliments his friend on his punctuality. He says that he is 'cold and sick at heart,' and Bernardo is just as eager that he should be gone. He had 'come on the stroke of twelve,' and bids him get to bed at once. Bernardo eagerly asks, ' Have you had quiet guard ?'-that is, 'Have you seen anything?'-to which the other carelessly replies, ' Not a mouse stirring.' Then Bernardo, somewhat impatiently, 'Well, good night,' and bids him, if he should meet Horatio and Marcellus, tell them to hurry. For he was still nervous. They presently appear, he saying, 'I think I hear them.' Then another challenge. It must have been exceeding dark, for they cannot see each other, and ask, 'What! is Horatio there?' which shows that faces could not be seen.

Now, in all this is there not a vast deal that is poetical to be suggested, with due finesse and deliberation ? It is a little play in itself; but who has ever seen it played so as to convey the idea of all these things? But all that the stage-manager requires is that these subordinates should speak up distinctly, and like officers on guard. The suggestion of 'graduated horror' or 'growing sense of mystery' he would dismiss with an emphatic, 'Absurd! Never mind that.'

The fashion in which the ghost is made to appear is usually of a literal and practical kind. A man, often of a stout, robust build, is seen to stride across the stage in an affectedly solemn way, and pass out at the wing. Now, one could fancy a great 
deal being made of this-an indistinct apparition, not a shadow, but moving in an uncertain way, now pausing in a sort of hesitancy and gazing sadly on the soldiers. I could imagine his being unnoticed for some moments; then one of the party, seeing him, would, awe-stricken, touch his comrade, and silently point to the apparition. Then it would glide out as it came. Hamlet's later, 'Angels and ministers of grace defend us!' and the speech that follows have been worked by the tragedians 'for all that it was worth.' Their idea is a sort of agonized and gasping expression of astonishment, which shall be in contrast to the previous tone of easy conversation.

Again, there is an idea of attacking the spirit, for Marcellus asks, 'Shall I strike at it with my partisan ?' and Horatio encourages him to do so. They are turning hither and thither; one says, 'Tis here '; the other, 'Tis here.' And then Marcellus, still looking round wildly, says, ' 'Tis gone.' In all this bewilderment there is a vast deal to be developed by careful study and rehearsing, so as to suggest utter bewilderment and confusion.

There are other things, generally neglected, which might add to the mystery of the Hamlet ghost. When it appears to Horatio and Bernardo for the second time, the former usually addresses it in a careless style, which is rarely impassioned enough-for the speaker is in a state of agitation. Then the cock is heard to crow. This is naturally considered a rather dangerous piece of 'business,' and always omitted. And yet what a mistake ! for if judiciously treated it might be introduced, and would have extraordinary effect. It is an important element in the situation. The crowing should come from afar, from the remote regions at the back-the very back of the stage-with a faint sound, which would soften away any grotesqueness. The spirit, we are told, was about to speak when the cock crew; on which there would be a pause of suspense highly ' creepy' and effective, all starting and remaining silent. And here we might ask ourselves : Why did the author introduce this grotesque effect if he did not think it essential ?

Horatio says,

'I have heard the cock that is the trumpet to the morn,

Doth with his lofty and shrill sounding throat,' etc.

And Marcellus then says, 'It faded on the crowing of the cock,' and he then tells how at Christmas 'it singeth all night long.' 
Who thinks of the picturesqueness of the words 'it faded'? We hear the sudden sound far away. Then the ghost, who had been advancing, checks itself, and seems to dwindle-gliding off, as though it would escape into thin air. Then there is the breaking of the clouds - the coming of the dawn. When they tell their story to Hamlet, they again dwell on this crowing of the cock, and how lat the sound the apparition shrank away, all of which lends a religious or spiritual tone to the whole.

When Hamlet follows the ghost the scene is usually changed to 'another part of the platform,' and Hamlet asks, 'Where wilt thou lead me?' But there is no direction for the change, and it would be far more convenient if the same scene were retained, Hamlet being led away to the back. The two could come on together far off at the bottom, and make their way to the front.

There have been some speculations as to whether an impalpable ghost - that is, one visible only to the mind's eye-would not be more impressive and effective. The bard himself seems to give us a hint of the practicability of making the Hamlet ghost invisible, for later it speaks from 'the cellarage' below ; and who will say that the unearthly 'swear,' and the bearing of the listeners at the interruption, is not always the most truly mysterious portion of the incident? This principle of invisibility might be applied when it first appears to Hamlet, for the ghost there says nothing, and both Horatio and Hamlet might fancy they see him gliding across until he disappears. Then Hamlet would follow it to the 'other part of the platform, where it might remain still unseen, and speak from some recess - say a cavernous archway. There is something here that commends itself, and it would certainly be more terror-striking than a robustious figure with a truncheon stalking about, as used to do the worthy Mead in the Lyceum days. How amusingly did ' $\mathrm{Boz}$ ' suggest this grotesque truncheon element, where he described Grummer arresting Mr. Pickwick; and beckoning to him with his truncheon in a solemn and ghostly fashion.

It has long been the fashion to array the ghost in Hamlet in a sort of greyish cloudy dress-supposed to represent something misty. But are we not told that he wore a full suit of armour from top to toe? This seems far more appropriate, as the late King had led armies to battle. Not that the armour 
should be of a shining, glittering sort, as if of aluminium. It should be of a dark, dull metal, richly wrought. 'He wore his beaver up,' which would show the white, ghastly face encircled, and thrown out by the dark framing of the beaver. This should be thought out carefully. I fancy, too, the gait of the ghost should not be a regimental 'stalk,' but solemn, full of hesitation and uncertainty, as though in a strange land and somewhat bewildered.

At the opening scene, where the King and his Court are shown, 'Enter,' says the direction; but with us they are usually 'discovered '-I think with loss of effect. In a Court of our day the King and Queen would come in first, not at the head of a formal procession or to martial music, but conversing as they walked- ' Though yet of Hamlet's, our dear brother's death,' etc. This would have a very natural air. At the same time, we have the first appearance of Hamlet, where the gloomy Prince is actually 'discovered ' and lost, as it were, in a crowd.

The King as portrayed by the legitimate actor is always shown as a very respectable personage enunciating his wise saws and reasonable admonitions with excellent elocution. One would expect the delivery to have an air of finished hypocrisy, elaborated, especially in the lines:

'Fie! 'tis a fault to heaven,

A fault against the dead-a fault to nature,

To reason most absurd, whose common theme

Is death of Fathers.'

The King's lecture to Hamlet on his excessive indulgence in grief is a truly rational and excellent exhortation, convincing even in its way, and so it is always delivered impressively, and so accepted by the audience. It seems to accept it in this

* When Booth, that somewhat artificial performer, appeared in Hamlet he arranged his first entry in a thorough businesslike fashion, so as to produce a striking effect. The King was prosing on to the courtiers, as usual, when of a sudden there came a pause; the crowd of courtiers parted and formed a lane, while in came Hamlet, tripping it with much energy, smiling and bowing, till he found himself well at the footlights receiving the applause of his countryfolk, who were present in large numbers to give it. This old fashion in his dress seemed to carry us back thirty or forty years, to the days of stock costumes-puffy trunks and hose, etc. The surprise was almost ludicrous. His 'business' and properties were all equally antiquated. On the whole, it may be said that lrving was the best and most satisfactory of all the Hamlets we have seen. There was a romantic grace about him and something pathetic. 
sense, owing to the presentation of the King as a sort of decent personage who has, as it were, 'turned over a new leaf.' But it is clear the utterance is not hypocritical. He means it all. We have only to turn to the magnificent and truly moving burst of repentance later on to see that the man had good instincts, which were overborne. He murdered his brother, no doubt; but these were days of violence, when the dispossessed ruler, as a matter of course, was put to death for fear of troubling his dispossessor.

After dismissing Voltimand and Cornelius on their embassy business, the King, turning to Laertes, gaily says, 'What's the news with you ?' at which old Polonius, his father, might be immensely gratified. All this preliminary matter being thus dispatched, the King looks round for Hamlet, who remains abstracted and in a sort of reverie. Then, to keep him in good humour, he addresses him as 'my son.' Hamlet does not answer, but recoils from the term, and just murmurs, in a ruminating, sarcastic fashion, 'A little more than kin and less than kind,' not caring whether the crowd or the King heard him or not. Then, no doubt, there were smiles and meaning glances and whispers among the courtiers, as who should say ' another hit at his uncle.' This makes the King uncomfortable, so he thinks it due to his dignity to read him a lecture on his generally odd behaviour. As they go out Hamlet lingers to the last, the King and Queen expecting or inviting him to march with them; but he shrugs his shoulders, looks after them with anger and impatience, then, pacing up and down, lapses into his soliloquy.

The Queen was a remarkable woman-not the sort of helpless, passive, creature we are accustomed to. Her caresses, sentiments, are all out of the common-a woman of ardent attachment. Witness her love for her son and her singular love for her husband's brother; her grief for Ophelia, whom she said she really hoped to see her son's wife. Yet what a foolish 'nullity' she is made to appear. She must have been young and ardent-say about forty-but she is always given to some stout matron. In the intricate plotting she makes a figure, and yet in the acting what a ' goody-goody,' insignificant sort of person she is made to appear. She has character. She is infinitely distressed by her son's eccentric behaviour, and 
has the courage to summon him to her room to give him a serious homily on his conduct.

Another distorted figure, twisted out of all natural shape for the player's purposes, is Polonius. He is known to every one ; he is rather a favourite with the gods, for he is always done in the same way, after venerable traditions, as an old butt or buffoon, a tedious 'dodderer,' with much white wool on his head and carrying a white 'wand. Here is yet another instance of a character which should be restudied, wholly reconstructed -in short, visualized. How many types of this class are there about to this day-old fellows who have been in diplomacy, envoys at some German Court, obsequious, always smiling, telling little stories and recollections, grovelling before rank, chatterers, yet always refined gentlemen! Such old retainers of a Court as Polonius are usually found to be rather refined, if punctilious and shrewd, old fellows, with a firm belief in the all but Divine commission of their employers. Polonius, in our day, would surely be a Sir Peter Polonius, K.C.B., late envoy. His discourse to his son is always made to take the shape of a sort of solemn sermon, and is regularly 'preached' by the actor. But it would be surely a different thing in the mouth of an old Court official giving his son a hint or so as to 'getting on' in the world. Thus would it run: 'Now, my dear boy, attend to me. I want to give you one last bit of advice: Don't go borrowing or getting into debt, for that's low. Above all, dress well and like a gentleman, for a good tailor is always a letter of recommendation, especially with the women,' etc. One can easily conceive the lighter key in which these useful counsels should be delivered. It is a surprise to find that all through Polonius is a very conspicuous, capable, and commanding figure, and a skilled man of the world. We find him managing his daughter, managing Hamlet-or trying to manage him-managing his son, managing the King and Queen, and elaborately arranging plots of various kinds. He is a very rusé old man. When he was concerned to find that Hamlet was getting ' off his head,' he prudently ranged himself on the Court side. In his own canny way, his chief resource was eavesdropping, and he got the King and Queen to listen with him to Hamlet's ravings. He had innumerable threads in his hand.

How little understood is the event of the arrival of the 
players! It was an event prepared and insisted on; much was to depend on them. Now all strolling players are flamboyant enough; they make a 'splash' and a stir. They would strut in, a large party. Instead, we have usually two or three scrubbylooking fellows, full of their own importance. Polonius had laid himself out to forward Hamlet's plans as much as he could, to 'throw himself' into the private theatricals and encourage them in every way. He recalls his own early experiences. The whole is rational, serious, and consistent. Hamlet's rudeness to him was no doubt founded on the fact that he saw that the old man had designs on him-a fresh plot, in addition to the others going on about him-and which fretted and irritated him.

How elaborate his scheme for having his son spied on in Paris! He had already given him, as we have seen, admirable advice; but he knew youth too well to think it would be followed, so he sends an emissary after him, and it would seem the crafty old father, as the later Lord Chesterfield might do, wished to have it put about, by means of obscure hints, that his son was no milksop, but a sort of gay fellow. But it must be done without saying anything very distinct or compromising. It is, indeed, an exceedingly clever and elaborate system which he lays down.

Again. Let us take that absurd 'very like a whale,' as it is invariably given. What is the situation? The old courtier is anxious to keep the eccentric Hamlet in good humour; he is amused at being rallied. He has come with a message from the Queen, who wishes to see her son privately. Hamlet, who deigns to have his gibe and mortify him, answers by pointing to a cloud, which he says seems 'almost in shape like a camel.' He would like his opinion. Polonius answers as almost anyone else would do who was dealing with a flighty person, especially a royalty. We can see him shading his eyes, looking intently, and then hear him with a sort of obsequiousness exclaim: 'By the Mass! and it's like a camel, indeed.' There the courtier speaks. But the Prince, putting on an antic mood, says maliciously: 'Methinks it's very like a weasel.' And the old fellow, though committed to his former simile, perhaps taken aback, cannot bring himself to reversè his opinion altogether, but after a little study adroitly says: 
'It is backed like a weasel.' The back, at least, has some resemblance. Then Hamlet, scornfully, and determined to 'corner' him, chooses what is the very extreme, and totally opposed to both camel and weasel, saying, 'Or like a whale,' on which the old courtier, after a little smiling study, and with an air of sudden conviction, answers, 'Very like a whale,' as who should say, 'Well, really-er-now that I look again, 'pon my word, your Highness is perfectly right: it has very much the look of a whale.' Now here is a display of subserviency that is amusing. But no! it must be given as a sort of circus joke. The audience expects it and always roars.

But if Polonius's advice to his son be wise and excellent, how still more wise and admirable are his counsels to his daughter on her treatment of Hamlet! How shrewd, how worldly-wise! And again, how inconsistent with his being a comical old time-server! How gross the vulgar turn given to his remark, 'springes to catch woodcocks,' always greeted with a loud guffaw! Yet it is meant seriously, as who should say-for they can mean nothing else- ' Be on your guard, my child. These are the crafty tricks and devices of the practised roué.' And as he goes on with stroke after stroke of good advice, how inconsistent and puzzling it seems to hear such admirable sense coming from an old droll and pantaloon! How shrewd, too, did he show himself when his daughter came to tell him of Hamlet's forward and extravagant behaviour! $\mathrm{He}$ began to fear he had made a mistake in advising reserve to him. He now insinuates that it was all her fault. However, the prudent old courtier sees at once that the King should be told, because Hamlet himself would betray it.

In Ophelia we have always had presented to us the invariable conventional girl-interesting, sweet, and suffering, exciting universal pity, finally driven to madness and suicide. To this latter portion every actress turns-it is the crucial moment-with a view to play it for all that it is worth-to be distraught, sing snatches of song, etc. It is all sweetness and gentleness; the painters even show her as a Pre-Raphaelite maid. The main point is that she must be a sort of foil for Hamlet.

But is this the Ophelia of the play? On perusing the original text, we see that she has a marked character of her 
own, and offers a great variety. She is now gay, now serious. She takes a large part in the complications of the story. Is she not something of a flirt, if we may use the word in connexion with the bard? Indeed, she shows a sort of trained artfulness. That old plotter her father had planned that she should win Hamlet-a 'fine match'; but what if the Court seriously objected? He was not going to lose his place. But the Queen ardently favoured her, for everything that would hold or attract the suspicious and dangerous Prince, and so keep him quiet, would be favoured. Another part of Polonius's ' little game' was to affect to discourage the matter. Nothing is more characteristic than his training of the 'fair Ophelia,' to which the sweet girl lends herself in the most dutiful and complacent way. This is hardly consistent with the Pre-Raphaelite idea. It will be noted that at the same time her father had to warn her against her too demonstrative behaviour to the Prince. He saw the dangershe was too indiscreet; for he was a Prince- ' he may not carve for himself,' and could not 'mean business.' He tells her that it has been remarked that she was closeted with the Prince, and had of her audiences been ' most free and bounteous.' Hamlet's proposals, he warned her, were mere 'unholy suits . . . the better to beguile.' Her brother wished to know from her what was said, on which he proceeds to give the same counsel, but with rather a different policy. He proceeds to cross-examine her. She assures him that Hamlet had offered genuine tenders of his affection, on which the old fellow calls her a 'green girl.' She tells him of vows, appeals to Heaven, etc., which he again puts aside. He knows the world, and finally forbids her to have any further talk with him.

But of even greater significance, surely, is this solemn warning to his sister when he was departing for France, when he told her that she had not the slightest chance of winning Hamlet in an honourable way. Reasons of State required that he should make an important marriage with one of his own rank. At the same time, he seemed seriously to point to the other serious danger-that she would yield herself to his affection, to 'his unmastered importunity.' 'Be wary, then; best safety lies in fear.' That the daughter of a high Court official should need such a caution shows that such frailty was 
not uncommon. Her reply, which was flippant enough, seems to show that there was ground for his suspicion, for she virtually said : 'Mind yourself; don't preach to me.' Her father also had the same misgivings, and bids her be scanter of her maiden presence, adding, 'I feared he meant to wreck thee.' In this view Hamlet's speech to Polonius as to his daughter seems highly significant. After a little rumination, he tells him with earnestness: "If the sun breeds maggots in a dead dog, being a god, kissing carrion-' His thoughts turning to Ophelia and their relations, he would give the father a hint. Then, abruptly: 'Have you a daughter? . . L Let her not walk in the sun. Conception is a blessing, but not as your daughter may conceive'-that is, outside wedlock. This may seem far-fetched, but how else interpret the allusion?-unless, indeed, he wanted to scare the old man with imaginary dangers, and so get free of the daughter.

It is remarkable, again, how morbidly excited was Hamlet on this subject, for when the pair of courtiers came in shortly afterwards, he utters some very gross allusions, which are replied to in a corresponding spirit. Something of the same coarseness is shown in Ophelia's ravings. This is not a pleasant topic, but it is unavoidable, as it is an element in the transaction. And yet the public always look upon the Prince as one of the most refined and delicate-minded of men.

As to the young lady's artfulness there can be little question, for when her adroit father arranged that he and the King in ambuscade should overhear her talk with Hamlet she made no objection. No well-brought-up young woman would have relished this device, or have consented to it. Even the King had frankly told her that they intended to overhear all that was said, and then she sweetly agreed to two little pieces of deception likely to draw on the lover. The shrewd old Polonius thought that her standing about doing nothing would look unnatural, so he put a book into her hands and bade her appear to be saying her prayers. To this bit of acting she agreed. She opened the talk with the returning of some presents that Hamlet had given her. For-

'Rich gifts wax poor when givers prove unkind.'

But this artful stroke brought forth nothing, except a most 
uncompromising 'flouting' rejection with some unsavoury language. Hamlet also said, 'I have heard of your prattling, too.' It was certainly mortifying with the others listening. The King, quite convinced, dismissed the notion of attachment at once; it was clear there was nothing in it.

\section{'Love! his affections do not that way tend.'}

With this mortifying announcement poor Polonius could not exactly agree. He thought it all came from 'neglected love.'

Many generations of playgoers have been mystified by Hamlet's barbarous treatment of the girl in the well-known scene. It certainly seems unmeaningly capricious. It has been contended that he meant it as a display of his assumed madness; but if we accept the theory that some relation existed between them, there is more coherency in the situation. He may have found her complaints and importunities inconvenient and a hindrance to his plans, and thus have brought to an end the adventure by a violent quarrel. He shows his dislike to the whole family - to Polonius the father, Laertes the brother, and the persevering Ophelia, who, he thought, were fastening on him. In the end he actually killed all three, or caused their deaths! I cannot but fancy that he had read Ophelia's true nature as a scheming young person, who was doing what she could to secure him.

And why should Hamlet bid her 'get her to a nunnery' to take the veil? Perhaps he thought of it as a penitential retreat for her, just as La Vallière after her fall retired to a convent. His cutting speeches as to female arts of attracting, painting their faces, etc.-were surely not conventional. Could they have been meant as a real reproach? 'These arts of yours, your insatiable coquetries, have brought about the mischief, so now go into retirement; repent and leave me alone.' But these insults notwithstanding, Ophelia, though crushed and weeping bitterly, was in nothing daunted. She passed it over as a slight aberration. She had too much at stake to be put off by a little burst of ill-humour. She would be independent of both King and father, who thought her business hopeless. So she forgave.

There was the entertainment of the play coming on. This offered an opportunity, and here we find the suffering girl whom 
Hamlet had dismissed so violently, after leaving him almost in despair, coarsely, and, as it were, for ever, suddenly recuperated, transformed into an almost coquettish young thing, and meeting her lover's capricious advances in quite a flirting spirit. When the guests were all assembled for the play, she made the very boldest approaches to him. So overjoyed was she at his compliment, 'Here's metal more attractive,' that she allowed him to lay his head on her lap and tolerated his free and doubtful double ententes with the simple, tolerant remark, 'You are naught-you are naught; I'll attend to the play'-i.e., 'Fie, fie! naughty, naughty!' As who should say, 'Fie, fie, my lord-how very wrong of you! I won't speak to you any more!' Then she put all kinds of questions to him in her iunocence, 'which means this and that, my lord.' She certainly seems a very ' fetching' young lady-on this occasion, at least.

It is else difficult to know why the bard put this string of double ententes into Hamlet's mouth. It is noticeable that Ophelia seems to have received them without rebuke, and with an assumed coyness and pretence of being shocked. Even accepting the coarse licence of the old playwriting, it is extraordinary that a young woman would so behave. At all events, it destroys the notion of 'sweet innocence,' and shows clearly that Polonius's daughter was a well-trained 'hussy,' who was doing her best to capture the young Prince.

The natural refinement of our modern times has completely destroyed the true motive of Ophelia's madness. The common arrangement sets out that this is all due to the loss of her father; her snatches of song are made, on the common arrangement, to point to this, and so the King expounds it. Now, this is hardly likely to have been the result of the loss of a parent, however acutely felt. There would be passionate grief, hysterics, but not unsettlement of the wits or wild rantings. Shamed, disgraced, deserted, her father killed by her lover, her brother away-what was to become of her? Her wits left her. A courtier reported that people were making comments on her odd 'speeches, botching her words up,' evidently guessing that something was wrong.

It must be admitted that this supposed relation to Ophelia, which is a wild speculation enough, introduces quite a new and 
distorting element into Hamlet's character. We can hardly conceive him as the immaculate and virtuous youth who could thus lead astray a young lady of rank without any scruple, and then cast her off in so unfeeling and heartless a fashion. But it is clear such lapses in those days were not thought very serious matters. They were blunders, mistakes of policy, and her father's and brother's warnings were clearly based upon this view. It seems impossible, they urge, to gain him in an honourable way. She must take care and not act foolishly. The old Polonius's instructions to his emissary, Raymond, to spread about reports of his son's looseness of morals are not edifying, and show that he might have reconciled himself to his daughter's left-handed marriage, as he might deem it.

The Play Scene is usually accepted as an effective bit of melodrama which interests the audience; but somehow its influence soon passes away, and we forget it, overpowered by the final tremendous burst which all Hamlets introduce. Yet it was a far more momentous thing than a mere Court exhibition. It must, as Hamlet no doubt intended, have set afoot gruesome whispers and speculations. Why was His Majesty so disturbed and agitated? What did it all mean? It was to lead to the killing of Polonius, to the death of Ophelia, to Hamlet's expulsion from the country, to his projected assassination, to the revengeful attack by Laertes, and other horrors. All is forecast in this Play Scene, which should have far more impressive solemnity than is usually imparted to it.

What if the episode were given in a more excited and important style? To begin with, there should be plenty of space, and the whole should be set forth with due state-rich dresses and eager movement. Maclise's well-known picture showed a very large raised stage, with a regular proscenium, richly decorated, an idea he may have got from the late Queen's theatricals at Windsor. But a moment's reflection will show that this is too elaborate. It is, however, nearer the mark, for the players were certainly expected, and due preparation would have been made to exhibit them. But the effect in the picture is quite a too modern one.

The true disposition might be this: A spacious hall, with an archway at the end leading into another great chamber; and here 
would be the stage, erected for the festival, set off with suitable furniture. Here should the performers declaim in passionate style, promenade about, striving to realize just such a situation as there might be in the audience. There should be pauses at telling and applicable situations. The murder should be worked up slowly and tragically, the murderer entering in a secret, guilty fashion, looking round in fear of detection, retiring and advancing. All should act their best. The aim should be to affect the real modern audience, exactly as the author wished to affect his audience. The whole should be worked up to a pitch of tension, the audience wondering and growing a little suspicious of what was meant, some rising to see better, some whispering and murmuring. All this would at last culminate in the King's rising in agitation and dissolving the assembly.

After the poisoning Hamlet grows excited. The usual fashion is that he keeps his eyes fixed on the King, watching him and every movement-dragging himself across the floor, etc. And he is even made to roar across to him, 'He poisons him in the garden. . . The story is extant and writ in choice Italian. You shall see anon how,' etc. But this is all addressed to Ophelia, with whom he has talked from the beginning. She even has to tell him 'The King rises.' 'What,' he answers, 'frighted with false fire ?' So that he had not seen him rise. All which seems more natural and impressive than the favourite violent treatment.

It is difficult to understand why the dumb-show, which preceded the Court play, did not also affect the King in the same fashion as the spoken drama did. It seems, moreover, quite unnecessary, as it repeats the action of what was to come.

As to the sensational seizure of the chain, let us see how it is justified. After the Play Scene Hamlet is not in the least excited-remains perfectly calm. All the company had gone out. As soon as the pair are left Hamlet utters his stanza, 'Let the stricken deer,' and asks mildly if his conduct on the scene would not have got him a place in a company of players. There was really nothing for him to be so exuberantly excited about. The King had certainly shown agitation before the company. The little plot had succeeded; but there was much more to do yet-so Hamlet evidently thought. He was, indeed, 
not quite certain as to the result, and consults Horatio. It would be impossible for one who was in such a frantic, passionate state, after bounding into the chair, to begin reciting snatches of plays, and then appeal to his friends: 'Did I not act it well? Did I not ?' More curious still is his declaration : 'I'll take the ghost's word for a thousand pound'; that isand we should mark this-he was by that time all but convinced of the murder by the King's agitation, even if the test of the play were considered unsatisfactory. For 'Didst perceive ?' he asks Horatio.

Horatio. Very well, my lord.

Hamlet. Upon the talk of the poisoning?

Horatio. I did very well note him.

So that if Hamlet had thus rioted in the King's chair, exulting in detecting him and probing him, would he begin to reason in this quiet way, or appeal to his friends to back his opinion? It was only after slow reflection, therefore, that he saw that his shot had told, and that he had to appeal to Horatio for further assurance. The King, after all, only seemed to his Court to be unwell; even Horatio, Hamlet thought, might not have noted the guilty symptoms. The whole was, therefore, a quiet experiment of his own, but there was nothing to be so boisterously triumphant about, save that the play had affected the King uncomfortably. The proceeding is really of a quiet complexion, and after a few moments the deliberate and reflective march of the play is resumed.

A great loss of effect is produced by the recurring act drop, which is carried to excess. But how rational that the action should still go forward, culminating, as it were, instead of being abruptly closed. It was to be one long and continuous night's work. After chuckling with Horatio over his success, Hamlet must needs entertain himself with music, and so sends for the Court performers, whose strains he means shall reach the King and disturb him yet more. Then should come in players with those notorious recorders and other instruments, perhaps; and when they come in he carelessly takes one up.

The late Wilson Barrett carried out this notion of continuity in every effective fashion, abolishing all these artificial halts. $\mathrm{He}$ could not be convinced that after every 'explosion' or 
crisis all came to an end for a time, that we must rest and recommence presently. He applied the same principle to the Hamlet soliloquies, at the end of which the performer has it all to himself, and is left lost in thought.

The scene where the King indulges in his fit of penitence, properly treated, is a most pathetic and harrowing one, and, as every one who searches his own heart must admit, a perfect representation of the struggle which the poor helpless sinner endures when he strives to get free. The King is wrought up to despair, grief, and misery of the most acute form. He tries to soften his poor, hardened heart, but without result. It is a hopeless business, for without the gift of grace and some attempt at atonement nothing can be done. A person who felt as he did was not wholly bad, and on the road to pardon and grace. But the audience must have it that he is acting. The truth is, this is Hamlet's scene, and part of his 'business.' $\mathrm{He}$ is prowling about, listening. Many have been shocked at his truculent and bloodthirsty denunciations, but it is forgotteu that these are not purposes, but mere ruminations-thoughts flitting through an agitated brain. 'Shall I do this? Shall I do that? Here is a fair opportunity; or should I wait until he has relapsed into his old villainy ?'-a mere excuse to himself for putting the purpose aside.

There is always provided a sort of prie-dieu, on which the King kneels in a constrained sort of fashion. The priedieu is in a corner, set against the wall. But, as he was so agitated, he should be seen walking about, now stopping to passionately address his appeals to Heaven, with his arms outstretched, as people in foreign countries often pray. All this would be natural and infinitely dramatic. People in a fit of remorse cannot rest still a moment. Then fancy Hamlet in hiding, following these frantic movements with a strange curiosity. It all becomes a different thing.

And how dramatic it is! The repentant King, surging and struggling with his remorse, all unconscious that he is being secretly watched by his greatest and most unscrupulous enemy, and within an ace of being done to death. To give it effect there should be realism, extreme passion and colour, and a sense of mystery. But we should imagine Hamlet on tiptoenow peeping in; now drawing back, in fear of detection; now 
listening eagerly to catch the words, showing bitter scorn and scoff at each moral sentiment; now laughing harshly. What a contrast would be here! There is yet another touch of this penitential feeling, when the King suffers an agony on a casual allusion by one of the characters, declaring that it came home to himself and wrung his very heart. The man had certainly a conscience.

In connexion with the Portrait Scene, another incident in that long night in the Queen's closet, there is perpetual debate whether the two portraits hung upon the walls or were simple miniatures. These are rather vital questions. Granting that two material pictures were intended, this notion of the miniatures is not to be thought of, for such things were then hardly known. In Rowe's edition of Shakespeare (I7I2) we are shown two large half-length pictures hung on the wall, as though in a modern palace, which is, of course, absurd, for this was the Queen's own private closet or boudoir. It is obvious she would not like to have such a reminder of the departed, and her present husband, who, being touchy on the matter and so remorseful, would certainly have objected. It was a matter to be altogether forgotten. Neither would she have cared to have ' number one' and 'number two' placed side by side together. What does Hamlet say?

'Look here upon this picture, and on this, The counterfeit presentment of two brothers.'

Were he speaking of real pictures would he not have said, 'Look on that one there and upon that,' as he stood pointing to each? Then he describes them both, contrasting their features, and is most uncomplimentary to the reigning King. 'Have you eyes?' He was 'a Moor,' and she was blinded. Now, these gross blemishes would not be emphasized in what was a Court picture, where he would be exhibited as a personable man. He was therefore describing him from recollection. So when he speaks of his father as

'A combination and a form indeed Where every god did seem to set his seal,'

all this would be said of a real person, but not of a picture.

The late Wilson Barrett, in his London revival, conceived the odd idea of having two portraits on the drawing-room 
table, something in shape like cabinet ' photos.' The modernity of this was striking. After all, the notion of visible pictures will, I fear, never be abandoned. It is too good a piece of 'business,' that pointing, etc. But, above all, why would he describe the well-known faces to the wife of both as 'the counterfeit presentment of two brothers'?

Hamlet's dragging the body away is usually thought a flighty, capricious proceeding, and we soon forget all about poor old Polonius. But the incident is most potent, and influences all that follows, and that the unhappy Prince was now filled with the idea of completely hiding his bloody act by the process of hiding away the body-' safely stowed,' as he put it. We can imagine nothing more appalling than this moment.

But there is another important element to add to the horror. The King, when the killing of Polonius was told to him, seems to have been convinced that Hamlet thought he was behind the arras, and struck at him. This was sagacious enough, for Hamlet, as he dealt the blow, had exclaimed, 'Is 't the King ?' The Queen did not, however, then tell her husband of this speech, who says in his terror:

'O heavy deed!

It had been so with us, had we been there.'

But it looks as though she did tell him later, for the King, when he meets Laertes, asks him if he had not heard that Hamlet, who had slain his father, 'pursued my life'; and Laertes answers, 'It will appear.' It is clear that in the Court circle the feeling was that the Prince had aimed at the King's life, and that there was all manner of dark suspicions and whisperings. The King felt himself in serious peril, and exposed at any moment to some fresh attempt. He must either destroy or be destroyed himself. This might seem a ready mode of extrication; but there was the general popularity of the Prince, and the fond attachment of the Queen. What was he to do? He resolved to send him out of the country, and have him assassinated.

Thus the third act holds a series of stirring and momentous situations, all linked together. There is the Play Scene, as it is called-the Recorder incident, the interview with the Queen, the King's prayer, the killing of Polonius, the search for the 
body, and proposed banishment of Hamlet. All these tremendous things took place during one long fevered night, stretching perhaps to the small hours of the morning, the day breaking before the unhappy personages got to their beds.

And what a prodigious increase of dramatic effect, as one trouble succeeds the other without interval! This is no Utopian speculation, but the strict fact. When the play is done, Hamlet discusses the result of his exposé with his friend, and is presently sent for to the Queen's closet; for she sees that the situation is too serious to rest there. When that interview is over she hurries straight to the King, and gives him the first news of her son's rash act. Then comes the hurried search for Polonius's body, the sending for Hamlet, the persistent inquiries, and his stubborn refusal to give information. No one thought of looking for it in the chamber upstairs, where it lay for hours. Hamlet is then ordered away to England on the spot, and the King announces that he must set off that very night. What a gain if all these events were thus presented continuously in a solemn chain! What suspense, what mystery, what a restless feeling of having been up all the night! I do not know whether it has been calculated what length of time is covered by the action in Hamlet. It might be fixed, I think, at about three months or so. The important events in Denmark, as we have seen, followed each other closely, but there must have been two intervals during which there was a lull and nothing doing. There was the mission of the Ambassadors, who went and returned about the middle of the play; there was also the journey of Laertes to France-a very long one in those days, through rough Northern seas-and his sudden return; and, finally, there was Hamlet's voyage to England and his return. These occur at different periods of the play, and the interruptions might be nicely calculated.

As the poor distraught Ophelia both sings her ballads and offers flowers and talks at length, there is call for working all up into animation and into a picture of active insanity. This adds to the horror, for it offers contrast to the soft demureness and sweetness of the sane Ophelia.

The Mad Scene is a display of trance-as of one moving and talking in a dream. But madness is an agitated and varied thing. It has all sorts of moods, passing from fury to stony 
tranquillity. There are 'hurries,' quick utterances, slow ones, and eager gestures. 'Pray you, mark,' should be eager and excited. 'They say the owl was a baker's daughter' - a grotesque speech, and to be said grotesquely. Never enough is made of the words, 'Lord, we know what we are, but know not what we may be. God be at your table !'

Two really highly important characters in the conspiracy against Hamlet are the King's instruments, Rosencrant $z$ and Guildenstern. They have a regular history: they lend themselves, as his creatures, to the King's designs, come and go as he tells them, spy on the Prince, try to beguile him, and finally, being secretly appointed to murder him, lose their own lives in this service. He turns to them at once as suitable instruments.

They help, in truth, to convey the idea of Hamlet's almost complete isolation, and of the general combination that was formed against him, the King aiming at his life with these instruments; old Polonius striving to entrap him for is daughter; Laertes incensed because of his treatment of her; his mother alienated because of his coarse attacks upon her character; and this pair of courtiers quite ready to put him to death. This notion of a general conspiracy should be emphasized everywhere. True, he had Ophelia and the faithful Horatio with him, but the former he had himself of set purpose shaken off.

They should be represented as prominent, showy figuresthey should act their villainy. But how thin and unmeaning always appears Hamlet's pressure on them to confess that they had been sent to 'draw' him! They simply stand looking on, smiling and behaving with due obsequiousness to the leading actor. The King should have originally instructed them for their mission with great mystery and importance, and they should have come to Hamlet with a crafty air, as though they really meant to get at his secrets. These men were capable villains; they stuck at nothing, and undertook to assassinate Hamlet as though it were some trifling commission. What playgoer, by the way, has ever known that arch stroke of the King's - the appointing of Hamlet as his Ambassador to England, the more readily to get him away? This assassination of an important personage on a foreign shore shows how little was thought of killing in those times. 
It will be noted what a difference all these incidents must make in our view of the character and feelings of Hamlet. In the last scene he not only knew that his father had been murdered by the King, but that he himself had narrowly escaped being murdered at his instigation. And yet he could bring himself to comply with the King's wishes as to the fencing, and meet him with apparent friendliness. But it is plain that he was secretly hostile to him ; indeed, he only addresses him once during the scene. It looks as if he suspected him, for he had a foreboding-all was 'ill about his heart.'

What is always missed in the usual version is the effect of a night of horror, the sudden murder of Polonius, the question Was the murderer insane? or What was to be done with him?

Everything was confusion. Yet Hamlet's going awaybanishment, rather-is glossed over in the common version as a sort of careless incident, one of small importance. After a short absence he 'turns up' again at the graveside, and we think no more of it. No one asks Why? But it was a much more momentous thing. His presence to the King had become a menace and a danger. He had found a clue to the great secret; he had killed Polonius; he was going about abusing the King, on whom he might next make a personal attack. Indeed, the King told Laertes that Hamlet was favouring Fortinbras, a foreign general, and might use him to destroy his rule : on all accounts Hamlet must be got out of the country, and when out of the country, assassinated.

This abrupt return of Hamlet, which in modern versions is simply announced by his appearance at the graveyard, is in the original prepared for in a dramatic way. We have the sailor coming from the vessel to deliver a dispatch from Hamlet to his friend Horatio. A strange, mysterious letter it was, with ' much to tell that would make thee dumb.' He had boarded a pirate ship, he writes, but the vessel suddenly drew off and left him a prisoner. They had treated him well, and he had promised to write to the King on their behalf.

The confusion, therefore, and consternation of the King when Hamlet, whose destruction seemed a certainty, reappeared of a sudden in Denmark were overwhelming. The danger was so imminent that he felt he must destroy him at once, or be destroyed himself. 
Hamlet, when seeing Ophelia's funeral approaching, was able to make out at a distance that the rites were 'maimed.' This must mean that there was no religious procession, no cross, holy water, or possibly religious dress. There was but one priest, and likely enough no acolyte and choristers. The priest possibly omitted the Libera, De profundis, and solemn prayers. The ordinary stage-manager's exhibition is quite the reverse of all this. He must have his 'super' clergymen, striving to look pious, etc. The bell, however, should toll at intervals. It is remarkable that the Queen at the graveside announces that the marriage with Hamlet had been all but settled. But why was Ophelia thus branded? She had not committed suicide. A branch of a tree gave way, she fell into the water, and was drowned.

Was Hamlet's extravagant burst at Ophelia's grave, we may ask, genuine or assumed? Did he pretend to feel this frantic grief, so that all thought that he had gone mad? When he first learned from Laertes' exclamation, 'A ministering angel shall my sister be,' he merely says, quietly, 'What, the fair Ophelia!'

How absurd, then, the common train of priests in surplices, acolytes, incense, the fact being that the rites were 'maimed,' a bare prayer only being allowed-a single priest and his book! There were just the King and Queen, with attendants. How infinitely more solemn would this barrenness be! But these are mere suggestions, and I am convinced, by dint of deep and careful thought and due visualization, something satisfactory could be evolved.

Sometimes we have a clanging bell tolling solemnly; the belfry seeming to come from just over the actors' heads. Such sounds should be heard very faintly, as from the far-off churches. Sometimes the organ rolls forth its tones, coming from the corner, which is equally absurd. No, an air of desolation and abandonment is required-something that will suggest that this is the burial of a poor suicide. The priest should with open book appear to say a prayer or two down into the grave.

Ophelia's open grave in Hamlet has always a disturbing, unreal effect; it is treated in such a matter-of-fact style-an elongated trapdoor cut in the boards, which it is, in fact. There is the heap of real clay, the skulls, etc. But what can 
be suggested? how exclude this prosaic realism? Then we have the spectacle of Hamlet 'leaping into the grave,' a feat which could hardly be performed without certainty of breaking a limb. Even grave-diggers do not leap into their graves : they lower themselves or climb down. And yet to see the Prince thus cautiously lowering himself would hardly do. The whole scene, grave-etc.-is generally placed far too forward. There should be a large gloomy churchyard, stretching far back, so that the funeral train should be seen approaching from a distance. The coffin, too, has always the modern undertaker look, which is too modern. The conventional shape might be avoided, for in foreign countries quaint patterns are in use. How invariably, too, does 'the procession,' though there is none, come in at a Dead March pace, the 'supers' tramping it slowly and solemnly. The coffin should be hurriedly and rapidly borne in, for it was a painful and unpleasant business, and had best be got over quickly.

Hamlet and his companion always come on in a too 'stagey' fashion, he, as it were, intimating, 'Now you shall have my important scene with the grave-diggers.' We could fancy Hamlet looking round in dreamy fashion, recognizing familiar objects. He had been drawn by some mystic influence to the churchyard, instead of going straight to the palace. The talk with the grave-diggers is usually given in a half-jocular fashion : it is full of points for the actor. But it is clear that he was bowed down with misery and the awful sense of coming events which were casting their shadows. They have just returned from abroad, and are straying about in a dreamy fashion, uncertain what reception they may meet with at the palace, where they must presently encounter the enemy. They come on the churchyard, and find a grave being dug -an evil omen. This feeling should produce an uncertainty of bearing and a sadness. Then, when the man is seen approaching, there should be some alarm and flutter, with concealment.

In the talk between Hamlet and Horatio immediately after the interment is revealed yet another of the base plots of the King to destroy his stepson. He had sent directions to England that, on landing, his head should be struck off. That shrewd Prince, suspecting the treachery, got up in the night, stole the commission, rewrote it, with a direction that the bearers of the 
document should be instantly put to death. These were, of course, Rosencrant $z$ and Guildenstern, the King's instruments. Hence there was a regular, elaborate, and most fiendish plot for the destruction of the Prince. Hamlet relates that the vessel met a pirate, and that he was captured and released later. The two commissaries 'held their course for England; of them I have much to tell.' They were going to their doom. He contrived to get a letter sent to the King, couched in mysterious language, announcing his arrival for the morrow, when he would recount the reasons for his return. Here was a blow. The King, expecting news of his assassination, amazed and confounded, calls out at once, 'Are all the rest come back, or is it some abuse, or no such thing ?' It flashes on him that Hamlet has discovered his plot, or has perhaps murdered these men; so, grown desperate, he sees that something must be done, and at once, to get rid of his hated enemy. Then he develops his scheme of a fencing match.

What a gathering of horrors in all this! The two men plotting - the one to destroy, the other to baffle; the man he had sent away to be murdered on his arrival now posting back, inflamed with fury and eager for revenge. For now Hamlet held two of his secrets-one, the murder of the late King, which he would disclose, as it was already disclosed in the play; the other, his own plot for Hamlet's murder. So he must be put to death, and at once, as soon as he arrived. This match, by the way, was a clever thought, and, I fancy, was suggested by Hamlet's killing of Polonius, also apparently an accident.

Now, after all these complicated horrors, what a different complexion the trivial scene of the fencing bout assumes! But these matters have to be 'cut out.' We find the King, in rather childish fashion, suggesting the contest as an agreeable diversion-as, it might be, a game of lawn-tennis. Every spectator always feels there is something trivial and highly improbable in this; but when we know that it is the last resource of the royal gambler, led up to by stages, to be followed by a more desperate attempt if that failed, how different it all seems !

Omitted always, as far as I know, is the King's artful method of getting Laertes to fall in with the plot; for as Laertes was a 
gallant young fellow and would not relish assassination, he tells him of a great fencer, the gentleman of Normandy, Lamond by name, who so extolled Laertes' skill in fencing, saying that he could meet anyone. Hamlet, he added, when he heard of these praises, became quite envenomed with jealousy, and was longing to meet him. With this he proceeds to work on Laertes, asking, Did he love his father? And thus it comes about that the wondering spectator looks on troubled and anxiously as he sees the noble and generous Prince involved in this last deliberately-planned scheme for his destruction, contrived by the royal villain, who felt that there was not an instant to be lost if he would save his own wretched life.

How different all this from the exhibition of the frivolous Osric and his mission, which, when placed alone and unsupported, imparts quite a farcical tone! The whole appears as a sort of impromptu business contrived by a weak man, instead of being, as it is, the last touch in a craftily-planned scheme. What is further brought out by this deliberate arrangement of the matter is the generous and trusting nature of the Prince, who is so gained over by Laertes' handsome act of forgiveness that he lends himself gladly to the mal a propos exhibition of the fencing.

Under such treatment as we have been considering, it will be seen how infinitely the great play would gain in effect and impressiveness. Retaining all, but abridging all, 'should be the rule and guide.' 


\section{CHAPTER II}

SHAKESPEAREAN GHOSTS, APPARITIONS, WITCHES, ETC.

\section{MACBETH.}

A S I said, if we are bound to adopt the elaborate machinery $A$ and other 'effects' to produce illusion, the principles of such mechanism should be sought out carefully, so as to find what will harmonize with the Shakespearean intentions. In this view, the abundant supernatural visitations in the plays make quite a department, and require the most thoughtful scenic treatment.

It is a long distance now from the days when the ghost invariably ascended through a square hole in the floor and departed in the same way, this being received as proof of his ghostship; but other methods in use are no less coarse and cumbrous, yet are received complacently. There is an elemental simplicity present. The theatre is suddenly darkened-not because such darkening always precedes ghostly appearances, but because without it it would be impossible that the glaring lime or electric light would have effect. A fierce ring or belt of light is then projected round a whitened figure. As it moves the ring of light moves with it. After its business is done, the light is suddenly withdrawn, and the other lights of the theatre are raised. This is presumed to convey the idea of a supernatural visitation. It is, of course, quite an arbitrary assumption that supernatural personages always arrive in a blaze of light, which is bound to move about as they move. The trouble is we have no knowledge of the favourite ways of these supernatural visitors, and have to select this illuminated method as the most convenient.

The important ghostly plays are Hamlet,. The Tempest, Macbeth, Julius Casar, Richard III. It might be said with truth that never has there been a serious attempt to set these 
Shakespearean Ghosts, Apparitions, Witches, etc. 35

spectral appearances before us in a fitting way. Nigh 400 years of performances have gone by, yet little has changed in the old inchoate methods.

Shakespeare's treatment of ghostly visitants is based on the simple principle that, having come from the other world, they have merely reassumed their mortal aspect, and appear and behave like other mortal beings. This dispenses with the accompaniments of magic-lantern effects, rings of light, 'limes,' trap-doors, and the rest. These are mere arbitrary adjuncts evolved by the stage managers. A moment's reflection would show that neither light nor darkness has anything to do with their proceedings. They are characters in the drama; they talk and move about, and are dressed like other people. The trap-door has all but disappeared, but time was when the ghost in Hamlet rose through a square hole cut in the boards of a room, and was therefore presumed to have arrived straight from some regions far down in the bowels of the earth. As well might a person arriving in a lift at the top story be taken for a supernatural visitant.

The witches of Macbeth offer a difficult and perplexing subject for treatment. The vulgar theory is that they must be presented as revolting, unnatural monsters, half old women, half old men, with croaking, 'charnel-house' voices. They convey nothing probable and nothing horrible at all by these croaking voices, only something tedious and unpleasant, which we are glad to be done with. The point is how the sense of awe and terror is to be induced. I believe only by touching the notes of interest and romance. They should be aroful beings, not repulsive ones. Antics and grotesque jumps and gestures and hoarse or squeaky voices are pantomimic and ludicrous. And why should they always have forked branches of trees in their hands?

No one has ever thought of trying comparatively youthful witches, with rational tones of voice and reasonable emphasis. Some of much commanding presence are to be seen in the old paintings of Macbeth. I could fancy at the opening three tall, gloomy, but stately figures standing revealed on a high place, and beckoning mysteriously to the thane. There should be the idea of power, which cannot be associated with decrepit, unintelligible, old hags. Equally unpleasant and uninteresting 
is the coarse and hoarse nasal chant with which they usually declaim. Of such witch presentations Elia writes. These, he tells us, 'Shakespeare has introduced to give a wildness and supernatural elevation to his scenes, as if to remove them still farther from that assimilation to common life in which their excellence is vulgarly supposed to consist. When we read the incantations of these terrible beings, is the effect other upon us than the most serious and appalling that can be imagined? Do we not feel spellbound, as Macbeth was? But attempt to bring these beings on to a stage, and you turn them instantly into so many old women, that men and children are to laugh at. This exposure of supernatural agents upon a stage is truly bringing in a candle to expose their own delusiveness.' The conclusion he draws is the abrupt and somewhat forced one that the plays should not be acted, but read; but, without going so far, we can deduce the principle that they should be introduced without any of the vulgar and grotesque attempts to make them hideous and revolting. They should act all they say and do with fullest intensity; for they are actors, and, further-it is always forgotten-of a highly dramatic sort, who should assert themselves and control the action. But they are usually shown as inferior supernumeraries.

It may be said that the mistake in dealing with the spectral parts of the play has always been the making a specially elaborate and laboured effort for each exhibition. It should be an insinuation, a suggestion of mystery, and belong to the larger whole of general effect. Thus the first scene, which is only eleven lines long, shows the witches deciding to go forth and meet Macbeth. Then comes Duncan's Palace, and after that the heath and the witches again. Now, these two witch scenes are usually made into one for convenience' sake; and yet, as we read the play, the two scenes add to the effect. The first ought to be simply a glimpse en passant, a visionpresented in a moment and gone in a moment. Such hurried glimpses add to the sense of mystery. This would be feasible with 'cloth' scenes; but our moderns must have a regular constructed scene, one that shall be complete, and then be changed with whirlings, flappings, etc. To my idea, all these short snatches of scenes should be like something in a magiclantern-a parenthesis, an aside-just lightly touched. Our 
revivalist will have none of them, as being too troublesomehe abolishes or condemns them with others.

The witches' cauldron, with its spectral images, never impresses supernaturally, as it ought. Neither audience nor actors feel the least awe or conviction. It seems a magic-lantern business. First comes the usually abrupt darkening, which gives palpable notice, then the lime-light. (Who minds this nowadays? It is so familiar ; actress or actor often having two 'limes' apiece following them about the stage.) There should be indistinctness and mystery, so that the audience should be, as it were, trying to make out what is going forward through the gloom. Shakespeare's object was to scare Macbeth by supernatural visions; he never contemplated doing this by glare and flaming apparatus. There should be something glowing, much as we see images in the coals and embers. The stage should be wrapped in gloom, not in that coal-black darkness, which is a different thing.

And the cauldron-how commonplace! A housewife's pot boiling on the fire. It is a bit of the 'property man's' business. We hear the stage manager ordering his cauldron, instructing the 'lime-light man' how the red fire is to be turned on and blaze up. No one ever sees even an attempt at doing this with due mystery. The child's head is pushed up and goes down again in a jerky and matter-of-fact way; and yet, with thought, study, and common sense, quite a different result could be obtained. Take, for instance, the going round the cauldron by the witches, who usually join hands and dance grotesquely. This ought to be a slow progress, each detached, each acting something exhibiting horror or demoniacal fury. It is always forgotten that they are persons of power and dignity, not pantomime shapes.

This has always been the weak place of every revival; and how much more could be made of it all! We are shown ' a dark cave, in the middle a great cauldron burning'-that is, on a fire. The whole stage should be the cave, not, as is usually shown, an opening of rocks-an arched hole cut in the scene. There should not be the common or cottage 'pot' which hangs over the fire, but a huge, imposing vessel of glittering copper, with a wide flange. Then, flames in a cave naturally produce a deal of smoke, which should be shown and 
reflect the light. The witches 'march round' the cauldron and throw in the ingredients. This march should be grotesque, spasmodic, interrupted at times, and not a processional one. When Hecate arrives with three more witches the party becomes reinforced, and all sing their ' Black spirits and white.' Here there should be no harmonized modern music, but a sort of savage strain in unison, so that the words may be heard, which we rarely hear. Of a sudden they hear Macbeth outside, and there is an abrupt interruption, with fresh and fantastic grouping. They listen, confer, grow agitated, and go to meet him. He demands to be shown the spirits; and then, we are told, 'an armed head rises'-i.e., one arrayed in a helmet. This helmet should be emphasized and on a large scale, and the figure below white. Clouds of white smoke or mist should rise. So with the apparition of 'the bloody child,' which is crowned, with a tree in his hand, the witches all this time waving their arms and making passes, etc. The cauldron then ' descends'-i.e., vanishes-and the ground is left clear. A good effect would be produced if it descended through the flames, which still burned on until they became extinct.

The very suggestion of the magic procession of Kings impresses. It ought to be an ever-brilliant and imposing thing, the scene changing to a glow of lights, with glitter and effulgence. There should be music, too, as directed ('hoboys'). Yet it is always presented in the most literal, commonplace fashion. The fellows tramp past. They should each act it. The figures should enter among the trees, each after an interval-not in a procession, as is so commonly shown, but after pauses, with a slow and saddened gait. They should be misty, shadowy things. The witches then, seeing Macbeth depressed by their show, indistinct at first, cry, 'Cheer we up his spirits! charm the air to give a sound,' etc., on which there should be more pleasing music, with some fantastic dancing, at the close of which they all slowly vanish. Cave and all might disappear, and Macbeth be left on an open heath, as if wakened from a dream.

In truth, to act a ghost suitably would require thought and study. Why should we not conceive them as poor faltering creatures-uncertain, hesitating, released for a time, restored to strange scenes, and therefore gliding about, stopping short, looking round in alarm and flutter? But our too literal sense 
must put all into black and white. They profess to be ghosts, and should behave as such. In the magnificent opera of Fidelio there is one scene of great pathetic interest which furnishes a hint-where the prisoners, by a special act of grace, are released from their cells and allowed to walk in the prison yard. In the common performances, even at Covent Garden, they came in en masse, in a great crowd, and immediately struck up the effective 'Prisoners' Chorus,' expressing their delight at the sunlight and the chance of liberty. But in the beautiful classical revivals at Paris and Dresden it was quite another thing. The prisoners come dropping in one by one, or in small groups-now from this side, now from that, amazed and dazed, wondering and delighted. Many moments passed before they realized where they were. In short, it was a display of genuine acting, and some time elapsed before they broke out into their impressive wail. This could all apply to the procession of shadowy Kings, which, as I have said, could be 'worked up' into a striking and awe-inspiring spectacle. Every ghost should be made emphatic; the whole should not be huddled over; nor should the lights be turned down, and raised again abruptly when all are happily got rid of.

This Banquet Scene in Macbeth has been arranged in many ways. It is a most powerful and effective, even melodramatic, one. Time was when a homely table and a cloth covered with plates were laid. Irving showed a vast barbaric hall, with quite a number of rude tables stretching away, all placed askew. It had a fine royal effect. Macbeth has, of course, his talk with the murderer at the side while the guests are waiting to begin.

But how clumsily this is always arranged-actually in presence of the guests! To some at least the murderers must have been known as doubtful characters. Macbeth should assume a suspicious, secretive air, and see the bravoes, in some retired corner, or at a door, or going behind a curtain, giving them their instructions in whispers, looking round in guilty fashion. But this is never thought of. The guests see the whole proceeding-nay, hear! For the appearance of Banquo at the feast the revivalists have expended all their ingenuity, but with little success. The problem is a most difficult one, for the spirit is invisible to the company and visible to Macbeth only. The old way was the simplest, and, according to the bard's 
direction, Duncan walked in slowly and took his seat at the table. Charles Kean, as I well remember it, used an odd device. One of the stout Norman pillars suddenly became illuminated and transparent, and within it the figure was seen to rise! This was simply an absurdity and unnatural in every way. The basis of correct treatment would be for the imagination to exert its powers and try to conceive how such a scene would be in real life, where the host was subject to a hallucination of the kind.*

The magic-lantern treatment does not strike with awe or terror. The obvious natural way was the old one, where Banquo walked slowly in, like some mortal, and took a seat unseen. To give effect to this entry, all should be engaged laughing and talking-a hum of voices-while the ghostly figure glides on. Gradually and unconsciously he becomes isolated. He sits leaning his head on his hand in a pensive way. There should be no darkening or 'lime.' The recognition by Macbeth is always too sudden. It should be gradual and uncertain : at first a start-' it cannot be'-a stooping forward with strained alarm and terror in the face, and all without speech ; then a frantic pointing, still without a word, approaching and addressing empty space with such earnestness that every eye would be turned to the spot, under the impression that something was there. If this were done in a vivid and realistic way, the effect would be far more powerful than any transparency or 'gauzes' would produce. Anyone that has seen a person under the influence of hallucination-say, from delirium tremens-will recognize how convincing on others is the effect of the seer's visions, and how uncomfortable it makes them.

\section{Julius Casar.}

The ghostly visitation of Brutus in Julius Casar, after the quarrel with Cassius, is truly awe-inspiring, provided it be handled suitably. How is it usually done? In matter-of-fact style: stage darkened as Brutus begins to read; enter ghosts at once; a start from the seer, and he goes out again. All is over

* Mr. Bourchier in his revival had a throne set up in the centre, with a special table for himself and the Queen, which had an odd effect; other small tables were disposed about, as at a nıodern table-d'hôte. 
in a few moments. But to be made impressive how differently it should be treated! Let us see. There is a gradual preparation. The light begins to fail, and the night draws on. "The deep night is crept upon our talk.' There should be a gathering stillness and solemnity, lights twinkling, a faint hum in the distance, the whole moving slowly. The great folds of the tent are spread across the stage. Brutus is sad and solemn; he parts from his friend with many a 'good night.' The faithful Lucio is attending him with his instrument and speaking drowsily. Brutus, still restless and perturbed, seems to shun going to sleep. He walks about nervously; he then thinks he will have some of his retainers sent for, who will be with him in the tent, and watch while he sleeps. This trepidation and uneasiness is due preparation for the apparition. He makes them all lie down, though they would prefer to stand. Then he bethinks him of a book which he kept in the pocket of his robe. He would like music, and asks the boy to play and sing him something, which he does. Now, this tune should be only the mere beginnings of an air, and given in the very faintest voice, for the singer's eyes are heavy with sleep, and he at last drops off. His master gently takes his instrument from him, looks at him indulgently, and begins to pace up and down. Then he will read once more and sits down, drawing the light to him. 'Let me see. Is not the leaf turned down where I left off reading ?' Then he should read for some moments. All is graduated. The scene is one of perfect stillness, the two retainers slumbering, the boy in the chair deep in sleep. Brutus reads on. Restless again, he draws the candle to him, looks at it closely. Then he murmurs: 'How ill this taper burns!' He shudders, looks round slowly, raises the candle and peers into the darkness behind; reads again. Cæsar's ghost glides in slowly and stands behind him. Brutus raises his head, turns it slowly and sees the ghost, when he shrinks away and slowly stands up.

Now, one might ask, Is there not here a very rich and full detail and slow development of mystery? Yet how often have we not seen the whole dispatched in a couple of minutes, as it were, the lights darkened of a sudden to suit 'How ill this taper burns!' and the ghost arriving abruptly. It should all -every portion of it-be acted. 
There is a similar passage in Richard III., the arrangement of which is perplexing, but which becomes simple enough when we consider the early conditions of the stage. It is the scene in the fifth act, when Richard had ghostly visitants. $\mathrm{He}$ and Richmond appear alternately, each for a few moments; when one goes off, the other comes on, and both actually have their tents on the stage, and both go to sleep at the same time. When Richmond commends himself to God and 'lets the windows of his eyelids fall,' on the instant the various ghosts appear to Richard, who must then have been a few yards away from Richmond. But this, under the old or the new conditions, would have been impossible and ludicrous. The difficulty may be owing to our having abandoned the old logical and obvious system of lighting the stage. Nowadays we light the stage with the view of illuminating everything for the benefit of the audience, regardless of the scene. Everything, therefore, is bathed in light, and in the same description of light. Rooms, streets, forests, seas, are all lost in this one yellow blaze, which is a fixed and constant quality. In the old earlier Garrick days the stage was lit, not by footlights, but by four chandeliers, which were suspended over the actors' heads, to illuminate their figures and faces. True, they gave the same light in the case of a street or forest ; but, still, it was obvious that the object was not to set off the scenery, but the persons. In a room it seemed natural enough, and in the old prints we can see that it is nighttime in a room, where introduced lamps served the same purpose as do lamps in real life. Now, here is a scenic principle with a very telling result.

The modern way, I believe, is to have two successive scenes, one for each King.

The long series of apparitions before alluded to are difficult to present in an impressive way. There are eleven in all, and each has its speech. Anything in the way of magic-lantern business mediums, etc., could not produce any supernatural effect; but the chief cause of failure is usually the starved, meagre attempts at representing a tent or a general who is on a campaign. It is shown as a skimpy triangular opening with a peaked top, being, in fact, cut out in profile. It is, practically, a cloth with another cloth behind it. Now, in practice a general's tent was a large, spacious enclosure, 
with several apartments. The whole stage might represent the interior. After all, it would be so difficult to follow the Shakespearean stage direction of having the two tents in view at the same time. Richmond's might be shown afar off by the aid of stage perspective. In those days of close quarters, of spears and swords, each would be perfectly protected from each other, by sentries, etc. No doubt the original arrangement was that Richard was shown on one side on his couch, as in the well-known picture of Garrick, while Richmond's presence was somehow indicated at the other side. The ghosts turn from one to the other, addressing each alternately. This, as we read, has a singularly dramatic effect, the spectral figures passing by with their solemn utterances addressed to each of the sleeping chiefs. But the modern manager shrinks from this complex procedure, cuts the scene about and allots the whole business to Richard alone.

Of course, in the old days the stage was simply a platform from which the actors could address the audience. The place changed automatically of itself. So soon as the scenethat is, the action of the actors-changed fresh actors came on, and they brought their place with them. Thus, in the present case, when Richard appeared he was in his own camp among his tents, and when Richmond came it was his camp. The audience understood this arrangement perfectly.

The visit of these victims to their murderer requires in the treatment a good deal of thought and care. Irving did not attempt any phantasmagoric effects. He let the living figures say their say and pass on. This seems to be the dignified method. How would we imagine a ghost of this kind to present itself? It makes all infinitely more impressive and creepy. We note the solitude, the silence; the King dozing, leaning on his hand ; the candle casting shadows into the corners of the tent ; then the restless movements of the tenant, his walking about, then turning to doze again. Presently there is an indistinct something white at the back, which hovers between light and darkness, then other white things begin to appear. How much more natural this-or something of the kind, at least-than the abruptly plunging the stage and theatre into black darkness, with the 'limes' beginning to work unsteadily, and so giving notice to everybody that the ghosts are coming and will arrive presently! 


\section{The Tempest.}

The Tempest has never been in much favour with managers or playgoers, and yet what a noble, stately, truly supernatural piece it is! What an interesting and commanding character is Prospero! But our actors have always drawn away from him, protesting that he 'preaches' and is monotonous. There is also a lack of 'business.' The truth is the part requires many histrionic gifts, some great force and even pathos. To Irving it would have been well suited, though he did not fancy the character. He would have given a beautiful and refined spectacular display, and his own rendering of the character would have been noble and impressive.

Mr. Tree certainly infused the poetical tone and spirit of the whole, and might himself have attempted the magician with some success, instead of the more melodramatic Caliban. In this place I shall deal chiefly with the supernatural elements of this fascinating piece, and the principles which should regulate them.

The popular fancy has ever been attracted by the spritely Ariel. Who has ever seen a thoroughly satisfactory Ariel or Puck? They have been always artificial instead of spontaneous things, affecting a nimbleness and elasticity they did not possess, and performing cumbrous gymnastics to show their sprightlinessovergrown tomboys, in fact. They were obliged to overdo the satirical smartness of the parts. That quaint and singularly original performer Louie Freear was once cast for Puck. It was well 'discharged' on the whole, but the effect produced was that of a mischievous imp who indulged in pantomimic antics. From the long speeches and narratives allotted to him, which are so often serious and thoughtful, it is clear that Puck was a capable spirit, carrying out the plans of his master; and it must be remembered that he winds up the play and utters the final words by way of moral.

Ariel, no doubt, with all its fanciful caprices as a spirit, is an embarrassing creature to deal with. The difficulties are enormous. If an attempt be made to represent literally the supernatural feats, we get into the mechanics of pantomime; if this be not done, there is the obvious contrast between the supernatural claims and the utter lack of performance. 
Take, for instance, the attempt to realize the flying on a bat's back-a mere façon de parler, after all, uttered in a song, and not necessarily to be 'done in action.' Mr. Tree placed his lively spirit in a sort of bush half-way up a tree, out of which Ariel peeps, and at the words ' On a bat's back,' etc., flutters and rustles the pendent leaves and tendrils, as though actually riding the bat.* This was done by the heroine in a pleasing and fanciful way, but the looking forth from the bush has something grotesque and artificial. It seems as if the property garlands, leaves, etc., were placed there on purpose. On the whole, however, the performance had something engaging and natural and was Shakespearean to a certain extent.

It is also usual to exhibit Ariel as a nimble, sprightly creature, who is expected to bound about here and there, as though restraining herself from actual flying into the empyrean. Miss Tree's late performance of the part was really an interesting and rather poetical one, in spite of her tall stature. But I fancy this restless agility is not actually necessary for the part - that is, the idea of lightness and movement may be conveyed by other means. There is a graceful gliding motion which could suggest as much.

Unfortunately, the supernatural elements in this great play have always been dealt with on 'stage-managing' principlesthat is, in prosy fashion.

The manager was determined to make a really original, sensational character of Caliban-a new and striking ' monster,' that people should wonder at and shrink from in terror, much as they did from Jekyll and Hyde. He made an animal sort of creature of him, with an added tusk, who grovelled and crawled. But these things would hardly carry out what was intended. The monstrosity must be acted, the horror inspired by what is said and the manner of saying it; no exhibition of tusks and long hair will do this.

Mr. Tree rather lacked the conviction of brutal force and passion. The truth is, the character is eminently tragic and savage. How nobly grovelling, with yet a sort of canine attachment, is the kissing of the traveller's boots, which here was made a bit of

* I once saw an intrepid Ariel, who actually mounted a 'practicable' bat of huge size, rode him astride, and was slowly hoisted aloft to the sky-borders ! This was illustrating ' On a bat's back I fly' with a vengeance! 
comic or funny 'business.' His complaints as to the way he had been despoiled-his island taken from him-should be full of a passionate, fiendish anger. The result was that the character, which should really dominate, became unimportant, for it reacts all through on Prospero.

Prospero, it seems to me, should be a personage of commanding power, with a full consciousness of that power. By his magic strength he can do all things. He should be above all the ordinary passions of humanity, and disdainful of them. All his utterances and declamations should be those of the prophet and preacher. Hence, when he shows his gratification at the progress of the attachment between his daughter and Ferdinand, it should be of a reserved kind, not the sort of chuckling satisfaction that an ordinary father would display at the prospect of a 'good match' coming off. So simple and homely an act as taking off his robe was intended as a stately and significant act, pregnant with meaning, not as here, where he seemed to say, 'Help me off with my greatcoat.' These are trifles, but they have purpose which should be brought out.

How prosaic and matter-of-fact is the bearing of the travellers when they encounter the supernatural exhibitions, hear the strange music in the air, being, as it were, distracted and bewildered by such things! None of the party convey anything of this. There is no attempt at dreamy mystery. They seem a lot of good-humoured tourists in an awkward place. Ariel's malicious 'You lie!' is treated as a sort of comical joke.

How little is this thought of ! and yet how much, if not the whole, depends upon it! I always think that complaint of the air being full of strange sounds conveys exquisitely the whole keynote of the piece. This should have been almost incessant throughout. The travellers wandering about helplessly dazed, bewildered, fancying spirits everywhere, yet not seeing them. Sullivan's lovely and tender motive, which recurs again, suggests all this in the happiest manner. This strain should have been ever in the air, and would have conveyed much. Our actors cannot be expected to know or realize these delicate nuances. They want their 'business.' But, still, a manager of poetical instincts could shadow forth all this poetical atmosphere for them, and could turn it into 'business.' The effect of the whole should be that of mystery. 
The system of working up a hint of the author, 'a graceful dance' into a formal ballet d'action, destroys the whole balance. It is always forgotten, both as regards the bard's works as in Molière's, that the dance is part of the dramatic action. The King or Duke has to be entertained, and they dance before him. It is in a 'chamber of the palace,' so half a dozen figures suffice. Here there is a masque: a few reapers dance with the water-nymphs.

We can understand this in Prospero's island. The naiads come from the sea; they are an apparition-dance for a few minutes with the reapers, and vanish speedily. The Cupid business is too elaborated and elementary.

In nothing has the failure of modern illustration been so conspicuous as in this play of the Tempest, because no one has thought of carrying out the author's intention, which was that the mystery should be found in the words and thoughts, not in blue fire 'mediums' and the rest of the modern apparatus. The stage directions are minute and curious, showing that much reliance was placed upon the magic effect:

('Solemn and strange musick, and PROSPERO on the top, invisible. Enter several strange shapes, bringing in a banquet, and dance about it with gentle actions of salutation; and, inviting the King, etc., to eat, they depart.')

'Solemn and strange musick' - that is, of the \#olian harp pattern, not tunes. A good composer might well understand what is wanted. It should be a short strain, but repeated over and over again in many a scene. 'Prospero on the top, invisible'-that is, to all upon the stage. Then are seen several strange shapes. This involves some study of the play-that is, of the sort of shapes that ought to figure in such a play. Something of the type is supplied by Ariel. They should not certainly be awful or repellent, but harmonize with the weird music.

The methods applied for producing the banquet for the famished travellers, to be carried off by the harpies, are always difficult to manage, and have usually an extraordinary suggestion of prose. At a signal there is darkening, and a sort of box-that is, a table rises out of a trap with attendant clatter. All this trap-work one would have supposed was exploded long since. Well-spread, enchanted tables do not of necessity 
come up out of the earth or through the ground. Here is a magic process, and to be done by apparent magic. The table should appear - that is, be discovered - as the group opens, and to their amazement. On some such line it should be contrived. It should disappear in the same way. But the whole effect of mystery should be shown, not by mechanical means, such as the unnatural sudden darkness, which always heralds the secret, but by the bearing of the spectators.

Sebastian calls the harpies ' a living drollery,' and adds, 'who, though they are of monstrous shape, yet note their manners are of more gentle kind,' etc.; ' such shapes, such gestures, and such sounds expressing, although they want the use of tongue ... they vanished strangely.' Now, here are a number of indications as to the appearance of these mysterious beings. Of what sort should be 'the banquet' they carry in? It should be spread on a table, as mentioned in the text, but it should be one of antique pattern, very low, dark-coloured, without a cloth, the supports stout and leaning outwards at an angle, with gold and silver vessels and flowers. A table covered with a cloth, as was lately shown, is altogether too prosaic, and has nothing in common with enchantment.

They dance about it with 'gentle actions of salutation, inviting the King to eat,' etc. This should be exactly what is expressed and no more-winning invitation, irresistible enchantmentcertainly not the favourite pantomimic methods. This was a regular trap on the part of the 'shapes,' or, rather, of Prospero; and the guests, in answer to the alluring invitation, would naturally cluster round the table with much complacency. We can see them grouping themselves, in fond anticipation of the rich banquet. It was the night, and so all was dark. 'Brother, my lord the Duke,' says Alonzo, 'stand to, and do as we.' But of a sudden come 'thunder and lightning.' ' Enter Ariel like a harpy'-that is, like an unclean bird of prey-'claps his wings upon the table,' and with a quaint device the banquet vanishes.' The popular conception is that Ariel is a girl, perhaps owing to its being always played by a woman, and it might be considered whether the effect would not be increased by the part being taken by a well-favoured youth. There would be more force and sense of power. The act of spreading the vast wings over the banquet would furnish a 
cover for the quaint device for carrying away the banquet. The table was left bare. Then comes a fine dramatic moment, when Ariel makes his threatening speech to the "three men of sin,' who listen trembling, quaking, and cowering. She seems completely transformed into a minister of vengeance, and at the close 'vanishes in thunder; then, to soft music, enter the shapes again, and dance with mops and mowes, and carry out the table.' This dance would be of a grotesque and impish kind-terror-striking. The carrying out the table should not be the common process, lifting and struggling to carry it along. It should fall into fragments, each shape carrying off a portion, and continuing their dance. Mr. Tree opened a trap-door and let it down. And yet on the stage of to-day there is no thought of all these creepy details; the whole is slurred over and 'got through' with much speed. The magic business is of the usual commonplace type-"'twill serve,' as they think. And yet it is not too much to say that this powerful scene contains the very essence of the mysterious element, and was meant by the bard to convey the fullest idea of Prospero's power and magic. All this assumes that we are dealing with these supernatural effects on modern stage principles; but the supernatural impression should in the main be produced by acting.

In the beautiful, truly romantic play how completely have all the opportunities, the feeling of incantation, fairyland, and magic power been overlooked! See that beautiful scene at the close, where Prospero reveals himself, and is about to break his staff. He says :

'When I have required

Some heavenly music (which even now I do)

To work mine end upon their senses, that

This airy charm is for.'

Then solemn music is heard; there enters Ariel before, then Alfonso, with a frantic gesture, attended by Gonzalo, ' Sebastian and Antonio in like manner, attended by Adrian and Francisco. They all enter the circle which Prospero has made, and there stand charmed.' Now, this is always done in a plain, literal manner, Prospero waving his wand, they walking within the ring, taking up their positions and watching events. It is evident what beautiful mystery might be cast over it all by the 
simplest acting even: Prospero majestic and awe-inspiring; they all bewildered, crouching, reluctant, overwhelmed with terror, the 'solemn music' going on all the time. Then Prospero takes up the strain :

'The charm dissolves apace,

And as the morning steals upon the night,

Melting the darkness, so their rising senses

Begin to chase the ignorant fumes,' etc.

All this should be shown in action.

After declaiming the beautiful lines, he then turns to Ariel :

'Quickly, spirit;

Thou shalt ere long be free.'

Here an unhappy composer saw his opportunity was not to be denied, and 'set,' and set very well, the well-known 'Where the Bee sucks,' and which Ariel is to sing as she helps her master to put on his rapier, hat, etc. She fetches them, and sings as she brings them, enchanted at her approaching freedom. The song is, in fact, her grateful answer. It is only a few lines long, merely warbled en passant, as it were, and has a most natural, charming effect. Miss Tree, however, got up into the branches of the trees, so as to convey, "Under the blossom that hangs on the bough.' And, indeed, Prospero's remark seems to support this view, as he turns and says, ' Why, that's my dainty Ariel.' Then, the song. The leader of the orchestra waves his stick, the noisy symphony strikes up, follows the long-drawn-out song-the high notes, the runs. Worst of all, the whole action is suspended and everybody enthralled, and even those who were enchanted are kept waiting. This dreadful orchestra business should be excluded altogether, and the song delivered unaccompanied. And how absurd it all is! for Ariel is panting to be gone:

\section{'I drink the air before me, and return \\ Or e'er your pulse twice beat.'}

But no! she must wait and wail until she goes through the whole of this 'show-off' song, with the encore.

Prospero reveals himself, when Miranda and Ferdinand are discovered playing at chess. A screen is usually drawn aside slowly, and an illuminated rock interior is shown, with the pair seated. This apparition should be contrived magically and phantasmagorically. Indeed, all through the 
piece I would have these mediums worked par exception. There should be constant cloudings, darkenings, and lightenings, misty visions, appearances and disappearances, all carried out rapidly and promptly, for dawdling over such things impairs the effect.

The first scene of Act IV., which is devoted to the apparitions, would need all the tact and poetry of the revivalist. Prospero was to bestow upon the eyes of the young couple some varieties of his art, and so we have Iris and Ceres and Juno, and the reapers' dance, which should be a most majestic vision. 'They join with the nymphs in a graceful dance,' which should have nothing of the ballet and no set movements-crossing and skipping, and the rest. It should be a generic dance, and without musical accompaniment, save perhaps something from behind the scenes. Then, before the dance finishes, Prospero starts suddenly and speaks, after which, to a 'strange hollow and confused noise, they heavily vanish.' Prospero was in a passion, for he had forgotten Caliban and his plottings. Then come his melodious chanting and haunting lines, 'Our revels now are ended,' etc. The enchanter was much wrought and excited. When Trinculo, Caliban, and the others come, and are about to carry off the plunder left for them, 'a noise of hunters is heard'; divers spirits in the shape of hounds come in, hunting them about, Ariel and Prospero setting them on. It would not, of course, do to have real dogs here, or even barking behind the scenes; but, still, after due visualization, some proper effect might be contrived. The hunters' cries behind the scenes, with barbarous sounds of hallooing cries and yells, yelps of animalsall are to be carefully prepared and arranged-the men with dogs' heads, hunters with stags' heads, etc., the whole done in alternate mists, darkness, and blaze of light. They go off, pursued, and agonizing roars and shrieks come from behind the scenes.

How usually prosaic do we find the representation of the enchanted scene where the invisible Ariel is bewildering Stephano and Trinculo with her interruptions! So matterof-fact is the treatment that it may be accepted as a bit of common life, while the audience might have assumed that Ariel was visible. The interruption, 'Thou liest! thou liest! 
Thou canst not!' ought to be given with much mystery, Ariel, creeping about on tiptoe, then approaching the ear of one of the party and saying slowly, 'Thou lie-est!' then dancing away. Trinculo gets the credit of the interruption from Stephano, so Ariel should speak, as it were, from his mouth. The scene is a most amusing one, and should be acted with all sincerity.

\section{FaIRIEs-The Chorus.}

How are we to deal with fairies? This form of the supernatural has really suffered, if it has not been destroyed, by the conventions of the modern theatre. The notion of fairies in the Midsummer Night's Dream has furnished an excuse for a sort of grand pantomimic exhibition-crowds of little girls flitting about among the trees, each, it may be, carrying an electric lamp. They wind in and out, in serpentine fashion, uttering little chirps or screams. Sometimes a dance is arranged. It is, in fact, a sort of ballet show.

Now, our bard's idea of the supernaturals was that fairies should form an element of his play, and each should have a distinct individuality; they were to be characters. When he exhibits a ghost, he does not present a crowd; when he shows us witches, he makes each speak ; when he introduces servants, he does not need a whole retinue, but gives each servant an individuality, much as Molière did later.

Oberon and Titania are important personages, people of great power, who control the course of the play, particularly in the case of the four lovers-Bottom, etc. They make long speeches, have their quarrels, and, in fact, dominate the whole piece. It is impossible to have respect for their power when we see them heading bands of little children, capering about, carrying lights, etc., and also, for no reason, so much smaller than themselves. There is no rule that a fairy should necessarily be a child. At the same time, it may be conceded that there is something pretty and poetical in such exhibitions. No, the notion of a fairy must be conveyed by the acting-by a sort of quaint uncanniness or queerness and oddity, with a certain airiness of bearing.

And this brings us to the difficult question of the class of performer that would be suitable to present them. Children or 
Lilliputian figures is an arbitrary assumption. Childhood has no necessary connexion with fairyland. Oberon and Titania are important acting parts, and no 'green girls' could do justice to them. Oberon should be played by a trained, intelligent youth, and Titania by a young woman. Then, for their retinue: no children again, for if the King and Queen be of mature age and stature, there is no reason why their followers should be of tender years-nay, it seems rather absurd. But again the real solution lies in the acting. It should be the acting of a fairy, according to our imagination and our lights. There should be a sort of airiness and irresponsibility, as though earthly matters were beneath them. This, of course, cannot be taught, but comes of instinct. With, say, a dozen graceful girls, with wings, if you like, each acting her part-constantly in movement, uncertain, peeping, hiding, disappearing-a telling effect would be produced.

Yet with all this we might be inclined to make an exception here, and be tolerant in this special case; for the spectacle of these flitting children is exceedingly pretty and poetical, and to Mendelssohn's lovely illustration much must be allowed. We must not be too rigidly reforming.

There is yet another quasi-supernatural element which Shakespeare has used but sparingly, and which he imported from the Greek drama. It is a melancholy reflection that we do not fully use the wonderful dramatic resources that the bard has placed at our disposal, casting about instead for all sorts of earthly devices-witness his chorus.

Our great author surely would not have introduced this Chorus unless with some serious purpose, or without the idea that, dramatically, it would be of help to him. And what was his idea of the Chorus, and, it may be added, of the one or two prologues which he furnished? It was to be the solemn, serious enforcement of the ideal-an appeal to the dramatic imagination, as who should say, Rely here not upon the vulgar imitative tricks of the stage, which will fail us. We cannot be in England and then of a sudden shift to France by merely changing a scene, but the imagination will do this for us. He felt that the exhibition of battles, armies, etc., which he was about to introduce profusely, would be feebly and inadequately represented, so that this was the only resource. We may wonder, 
however, why the bard applied the system of Chorus to this one play of Henry $V$. only, especially as the scenes in Henry VI. have the same diversity, passing in France as well as in England. This, I confess, I am not Shakespearean enough to resolve.

In Henry $V$. the Chorus, which is also the prologue, is a most essential portion of the piece, and is constantly appearing and reappearing. A very fine and dignified conception it is, and it really helps forward the action-that is, if fittingly presented. But it is not enough that an imposing lady, carrying a spear and shield, should come forward and declaim, as it were, during an entr'acte. She is intended to be part of the piece. At Mr. Lewis Waller's revival of Henry V., Miss Evelyn Millard discharged the part with admirable dignity and effect. She was shown seated in an arm-chair only a few inches from the footlights, which played fiercely on her, while a cloth, touching her shoulder, floated and drifted from the movements of sceneshifters behind. This was not exactly a classical method. No; she should appear in one of the existing scenes, which should be gradually deserted and left solitary for the purpose. It might be the sun setting or the drawing on of the night, with the growing stillness. Then she would appear a stately controlling spirit, and vanish as she came.

I spoke of the appeal to the imagination. In the fine prologues she calls for the muse of fire, "the brightest heaven of invention,' that would set Harry before them in all his splendour. ' But pardon, gentles all,' for their daring to bring forth 'on this unworthy scaffold ...' so great an object.

'Can this cockpit hold

The vasty fields of France?"

What was astonishing in hearing this appeal of the Chorus, delivered as it was with genuine earnestness, was its convincing character. All who listened felt that here was nothing but the simple truth-that we must appeal to our fancy and imagination if we would be really entertained, and that no amount of sham constructions, etc., would have effect in beguiling us. The naive information that now the English King was about to cross the seas and invade France, that we must put ourselves on board also and cross with them, was really most persuasive, and we became prepared, in short, to find ourselves in France, in quite new scenery. 
We are too apt to set aside in the modern revivals various arrangements and dispositions of our author's text, without considering whether they would not increase the effect of his drama. Thus, the Chorus is usually abolished as an antiquated, incomprehensible thing, hopeless to deal with.

To me, and perhaps to all present, this seemed a perfect revelation; it was a practical contribution to the march of the drama. The author seems to speak to us through the mouth of his Chorus as convincingly as through the mouths of his actors. He carries us forward, puts the intermediate events before us in a vivid way, and interests us as though it were a regular scene. It is a spoken panorama. Yet this valuable necessary thing has nearly always been overlooked or omitted. When used intelligently, I have noticed that the audience was attracted and absorbed, and followed the declamation with infinite interest.

And now let us see what actual help, in the shape of illusion, we gain from this element. At the opening of Act II. Chorus again appears to tell us that the youth of England are all on fire, the French expecting invasion. There were traitors in England who conspired with the French :

\footnotetext{
'Linger your patience on; and we'll digest

The abuse of distance; ...

The King is set from London; . . .

There is the playhouse now, there must you sit :

And thence to France shall we convey you safe,

And bring you back.'
}

What vivid words! And who could resist them? All listeners would see the things they were invited to see; their thoughts would travel between the two countries, just as they were bidden. Above all, mark the contemptuous dismissal of common stage devices.

In the prologue to Act III. we are asked to suppose that we have seen the King embark at Hampton. We are to play with our fancies and call up the image of the fleet.

$$
\text { 'Follow, follow : }
$$

Grapple your minds to sternage of this navy, ...

Work, work your thoughts, and therein see a siege.'

The Chorus to Act IV. gives us a charming night picture, which shows us what a camp on the stage ought to be.

'Now entertain conjecture ... .

The hum of either army stilly sounds.' 
And it then describes 'the fixed sentinels,' the sounds of the armourer, 'Fire answers fire,' etc.

This shows, by the way, how close were the hostile camps. We can only repeat that these noble and poetical speeches are as dramatic as anything in the play, and carry on the business just as effectively. But, then, they should be worked up, delivered with fire and imperative emphasis, so that the imagination thus eloquently called upon should be kindled and become responsive.*

* At Act V. the Chorus tells us :

' Now we bear the King

Toward Calais : grant him there; there seen,

Heave him away upon your winged thoughts

Athwart the sea. Behold, the English beach

Pales in the flood with men, with wives, and boys, . . .

You may imagine him upon Blackheath; ...

But now behold,

In the quick forge and working -house of thought,

How London doth pour out her citizens!'

Are we, the Chorus asks again :

' On this unworthy scaffold to bring forth

So great an object: Can this cockpit hold

The vasty fields of France? or may we cram

Within this wooden $O$ the very casques ...

$O$, pardon! since a crooked figure may

Attest in little place a million; . . .

Suppose within the girdle of these walls

Are now confined two mighty monarchies, . . .

Piece out our imperfections with your thoughts; . . .

Think, when we talk of horses, that you see them,

Printing their proud hoofs i' the receiving earth;

For 'tis your thoughts that now must deck our Kings,

Carry them here and there; jumping o'er times? etc.' 


\section{CHAPTER III}

\section{MUSIC-DANCING}

T HE question of Shakespeare's music is a large and interesting one. It seems to be admitted that Mendelssohn, in his Midsummer Night's Dream, is the only writer who found the right tone, measure, and quantity. You but hear a few bars of his enchanting strains to feel that it is true Shakespeare. Even the last three or four-the high treble 'thirds'-bring the whole drama before you. But who can touch that lyre? Accompanying his spoken text with music has been tried, and will not do. Mr. Bouchier in his Macbeth revival has, however, supplied a good deal of this element. The composer, a good musician, furnished a troubled, stormy overture, presaging the contending passions of the play. The notion of an overture is too conventional, and even vulgar-it is a sort of flourish of trumpets anticipation; whereas the play should begin in its own calm way, without any such noisy heralding. We cannot conceive of an overture to Hamlet. Mendelssohn's is so exquisite, that it has become an exception, and the play is in the nature of a fairy masque.

In this Macbeth revival there was something almost comic in the Scotch turn given to some of the music, so much so that we expected to see the pipers entering skirling. As it was, there seemed to be Scottish airs worked in, and almost suggesting reminiscences of Rob Roy.

There is nothing so destructive of illusion and dramatic effect as the stage music as it is commonly rendered. It is supposed to colour or intensify the situation. We know that the moment has come by the conductor getting into his seat, and beginning to beat time for the moving strains, his waving arms being conspicuous in the middle of the stage. Here is at once a link with the prosy outer world; it brings us down to 
earth again. It would be different were the executants wholly concealed, the music floating upwards from some unseen region. How absurd in the Midsummer Night's Dream, when the fairies are fluttering about in their dances, crossing and recrossing in the shadows, to see the fiddlers hard at work over their shaded lamps, and the conductor in evening dress, as prosaic as possible, whose moment has now come, gesticulating away at Mendelssohn's music. Usually the play is interrupted, and the song is virtually performed for the audience. The singer stands forward and pretends to play his lute, while the orchestra accompanies.

But let us turn to, say, a scene in Act III. of Henry VIII., and get some light. The Queen and some of her women are working together, and she says :

'Take thy lute, wench: my soul grows sad with troubles:

Sing, and disperse 'em if thou canst,' etc.

The other then begins ' Orpheus with his lute,' which is quite apropos, for she sings that

' In sweet music is such art, Killing care and grief of heart

Fall asleep, or hearing, die.'

Is there not here a dramatic action and guide for treatment? The 'wench' should unobtrusively, and unconscious of the audience, softly warble her comforting notes; the others should turn their faces to the singer, as if enjoying the strain and comforted by it, and whispering to each other. Of course it would be more conventional and effective to stand up and come forward, ignoring the Queen and the other 'wenches,' and take the time from the stick-waving leader. The lilt, having been set by Sir Arthur Sullivan or by some one of his measure, is sure to wind up with an obstreperous orchestral burst, during which, unless encored, the ' wench' returns to her seat.

When Irving came to this passage, he got the clever composer -German-to set the words 'Orpheus and his lute' to an elaborately harmonized composition for three voices-though the Queen plainly gives her directions to one maiden only-and so we had elaborate warblings and contrapuntal work. We might call up such a scene in the domestic life of our late admirable Queen, sitting among her maids-of-honour or ladies- 
in-waiting, working or turning over a book. Then she might ask one to go to the piano and sing her a Scotch song. This suggestion fairly conveys his idea of the situation.

The spirit in which this combination of music and Shakespeare was carried out will be gathered from a scene in the Irving revival of the Much Ado About Nothing, when in a garden scene Balthasar is bidden to entertain the other nobles with a song. Something surely was to be made of this, so our enterprising manager bethought him of Mr. Jack Robertson, a robustious and popular tenor, to whom I have no doubt he gave a record salary, not for acting, but for simply coming on and singing his one song. $\mathrm{He}$ was, as it were, specially engaged. When the moment came, the singer, who had been promenading it about the garden, was called upon. The nobles sit down while the singer stands well forward in the middle. Meanwhile the conductor is busy with the rattling symphony, waving his stick, and the singer, forgetting the professional listeners, seated behind, now comes to the very front and sings his best for the audience-'Sigh no more, Ladies'-all which is forced and unnatural. He should be sitting with the rest and sing to them alone. There should be no orchestra or man with the stick. As Mr. Robertson usually obtained a rapturous encore, there was much coming forward and bowing, etc., and all began again. The nobles, of course, had never asked him to sing it twice over. Much coy reluctance, until the tumult rose, while the seated performers remained more or less impassive. Then the man with the stick taps his desk; off we go again with the rattling symphony, and so da capo.

Let us suppose a grand seigneur, a Duke who has taken his friends into the garden after lunch or dinner. They have been talking of music, and the host recalls, say, the Mikado and a particular song. 'How good it was!' he says. 'But you know it, Jack. Do give it us now.' Here can we imagine the party seating themselves in a regular half-circle on the garden-chairs to listen, while Jack himself must stand and shout the lilt in his fine tenor, ending with a gay flourish, while the others would crowd to listen for two verses at the least with a certain encore. But was this comedy or Shakespeare, or the play itself? Would he stand up and advance into the middle, and 
all but turning his back on his friends, voice it for all that he was worth to some friends far away? How astonished would the friends be at such treatment!

There is a notable song in the Midsummer Night's Dream- I know a Bank'-which is a truly awful example of this purview. This lilt has been extraordinarily popular, and has set many an old head nodding. It is firmly established, is believed in as something almost Shakespearean itself. We know the formula and cue for orchestra-symphony, etc. Two presentable fairies come forward smiling, and go through the whole in thirds, warbling away melodiously with trills and flourishings, so as to enrapture all the hearers. It finishes triumphantly and to applause, and is, of course, encored. No one knows what it is all about, or why such warbling should be introduced. Yet in the text it is quite intelligible. Oberon wishes to enchant Demetrius, and sends to Puck for a certain magic flower. Puck returns with it, on which Oberon-

'I pray thee, give it me.

I know a bank where the wild thyme blows,'

and where Titania sleeps. With the juice of the flower he will anoint her eyes, and he further directs Puck to take the juice and anoint Demetrius' eyes. All this detail is lost or overlooked by the introduction of the modern harmonized song.

Thus Oberon's speech has been turned into a song, which was never intended by the author; and therefore the invariable rule should be that only what Shakespeare intended to be a song should be set to music, and that music should always take the shape of a spontaneous utterance, without interruption of symphony or elaborate accompaniment.

Again, in the same play, how the moderns have distorted the beautiful fairy machinery! Thus Puck asks a fairy, 'Whither wander you ?' She answers him in a bit of careless poetry-

'Over hill, over dale,

Through bush, through briar,'

giving him also information about the King. The composer, however, must seize on this as a splendid opportunity, for a showy solo, one very difficult and effective. Puck has to stand aside, look on and listen, while she-a female vocalist, introduced for a purpose, say Miss Parkina-is at the footlights for at least ten minutes, with roulades, fortes, etc., to say nothing of 
ensuring a certain encore. The vulgarity of this is inconceivable, and is wholly undramatic.

The Shakespearean songs always come in naturally enough if they are permitted to do so. Thus the familiar 'Blow, thou Winter Wind' in As You Like It, is truly appropriate to the situation. The famished Adam has been brought in, and food set before him by the Duke, who then turns and says, 'Give us some music, and, good cousin, sing !' This might seem inappropriate, for he wished to hear old Adam's story. But had he not said-

'Fall to: I will not trouble you

As yet to question you about your fortunes'?

meaning, 'You will be busy eating, so en attendant we will have this song.' Of course, all this effect is lost if the conductor gives the signal, and the orchestra strikes up, and the 'specially engaged' singer comes forward. No, some one sitting behind under a tree, without rising, will warble forth the song, the Duke and his courtiers watching with interest the performance of the hungry old man.*

- In many of the Shakespearean dramas we have a dance introduced, and here comes, the opportunity for the spectacular stage manager, who can only deal with it after his favourite methods; in fact, he knows no others. The leader, who has been sitting low down among his fellows, suddenly jumps into his high seat, taps his desk, raises his arm. The King and his lords seat themselves, and from the wings, right and left, run on or skip on a large number of girls, who group themselves down near the footlights and start off with their muscular antics. They keep their faces to the audience all the time, and really dance for it, and not for the seated royalties; and the movement goes on for several minutes. But how should it really be? First, such dancing as is furnished in a palace for the entertainment of the royal owner would ordinarily be supplied by a few performers-say, three or four, or half a dozen at most. They would perform their measures at the side, in obtrusive, graceful

* At one time, being full of a more than usual enthusiasm for the bard, I found myself dreaming of his characters, and could hear the chant of his melodious lyre. A beautiful Lady Paramount-like her in Twelfth Nightwas dismissing me, and I heard her say distinctly:

\section{'I pray you go hence : but pray keep wide open} The back-door of opportunity.' 
way, old-fashioned, and without jumps or boundings. The eye should rest on them as on a piece of tapestry or a scene by Watteau. The dance should be blended with a play, and not be an introduced episode.

In short, it might be said that in every instance where our author has directed music to be introduced as an aid to the dramatic interest, it has been seized on as an opening for actually destroying the beauty of the situation. The action is violently interrupted, the fiddlers become obstreperous, and the singer with a good voice, 'specially engaged' intrudes himself. But Shakespearean is, or should be, an inspiration to the musician. Mendelssohn alone has been thus inspired. It is not too much to say that his Midsummer Night's Dream music, when played in a concert-room, brings up all the images of the beautiful fairy play. We are conscious of the presence of the elves, and the exquisite pathetic passage at the close of the overture ever suggests the general dreaminess. Sullivan in parts of his Tempest-notably the 'Yellow Sands' motivehas something of the same tenderness and fitness. 


\section{CHAPTER IV}

\section{MODERN REVIVALISTS-IRVING}

$\mathrm{O}$ $\mathrm{NE}$ of the most welcome and almost miraculous elements in the Shakespearean plays is this: With a new performer in a leading character, we seem to have a new play before us. So rich is each, so much is buried, that curiosity, surprise and speculation are evoked afresh, and supply quite a new interest. It is exactly as in ordinary life, where a wellmarked character among our friends, however familiar, may always supply novelty. It is the same with the first-rate comedies, such as the School for Scandal and She Stoops to Conquer, of which we never tire; and so the public stock of harmless pleasure has been increased to an extraordinary degree. Most intelligent people will have noticed that they return home after witnessing a Shakespearean drama in quite a different mood, exhilarated, but, above all, with a deep impression left, as though they had witnessed some real series of events and met real personages. They find themselves-for a few days, at least-recalling the images, characters, incidents; whereas the ordinary stodgy drama of commerce manufactured in our day leaves no impression and supplies no agreeable memories. It is a mere show, machine-made; the other an intellectual exercise. We may, indeed, pause to question whether the general treatment and handling of these great subjects can be accepted as satisfactory, and to ask ourselves whether the mighty power of the bard has not really triumphed over all attempts at disfigurement.

Irving, then, struck the true note, so long dumb, kindled the dormant enthusiasm of the crowd, and really set the fashion for correct and elegant revivals. Our obligations to him are enormous. He was certainly the most accomplished of all the revivalists that can be remembered now, saving perhaps Phelps, 
but better far than Charles Kean. He had the truest instinct. But I have dwelt at length and in detail on this in my account of his life. It must be, however, admitted that he lacked reserve in his treatment, and made some experiments which were scarcely orthodox. For instance, one of the sensations in the great production of Much Ado About Nothing, and which became the talk of the town, was the really beautiful and most elaborate scene of the church or cathedral, with the attendant ecclesiastical shows. It was an amazing enterprise, delusive to a degree, elaborated with exceeding taste and delicacy. Even the picture of it by Mr. Forbes Robertson revives most faithfully all its romantic charm. The credit and inspiration are entirely due to Irving, and, it must be added, to his own invention and imagination; for it is nothing more. The author had nothing to do with it.

The bard's direction is simply 'a church,' which may mean either the porch or the outside, or a side-chapel. Suppose such an interruption had occurred in our time at, say, the Oratory; it would be most unlikely, and most ungentlemanly, too, for the bridegroom to have held back until the procession had emerged from the vestry, the candles been lit, the pair and their friends waiting at the altar. All that the poet would convey is that, one of the, clergy, meeting the wedding-party, put a question, which the bridegroom answered by declining to go on with the business. How much more dramatic-and serious, too-how much grander the situation, when put in this simple way!

Supposing such a scene of high ritual at the altar of a cathedral : who could conceive of a young lord stepping forward, and roughly bidding the celebrant to 'look sharp,' and cut out all superfluous talk and ritual? Such interruption is inconceivable. The beadle or verger would conduct him to the door. Yet it is not so unnatural if the ceremony was, as Shakespeare intends, a private, informal matter in one of the side-chapels of the fane, with so obscure an agent to perform the ceremony as a simple friar-no Bishop, Canon, Dean, or any one of position. These could not be addressed so bluntly, but a friar might be.

Every one familiar with foreign cathedrals knows what retired places such side-chapels are. They usually open out of some rambling and circuitous aisle. They seem debatable ground, half sacred, half profane. People talk and laugh, pass 
to and fro, for it is often used as a short cut from one street to another. Here the guests gather.

Again, the pleasant scene in which Benedick's friends purposely reveal Beatrice's liking is generally quite distorted from its purpose. In the Lyceum version it was worked up into a rare practical joke. The trio piled up its exaggerated accounts of Beatrice's passion in the most farcical way. They could hardly speak for laughter. There were constant shrugs and glances towards the arbour, whence Benedick would occasionally peep or emerge, showing a sort of comical discomfort and awkwardness. The fun became fast and furious, and the audience roared-all excellent business, no doubt, and too precious to be altered. Yet in the text it is another matter. The friends, including Beatrice's uncle, were really interested in the pair; they saw that some special effort must be made if they were ever to be brought together. In a previous scene Don Pedro tells them that he has a plan which will compass this. He heartily praises Benedick: ' $\mathrm{He}$ is of a noble strain, of approved valour and confirmed honesty. ... I I would fain have it a match.' There is no idea of laughing at him and making him their butt. When they know that he is listening they tell each other in the most business-like way how attached she is to him, adding and heightening the various details. It is, in short, a good-natured scheme. But the idea at the Lyceum seemed to be to convict him of being inconsistent with himself and his bachelor propensities.

As is well known, Shakespeare gave no directions as to his scenes. He gave them no names, but only numbers. The scene for him was the incident. So, in the Church Scene of this play he meant a place where people would come to-a church, a chapel, a hall in a palace-anywhere. The point for him was a marriage that was interrupted.

This was poignantly, intensely dramatic, and did not gain anything from priests, censers, dresses, and the like. Such rather impaired the effect. When the guests were dispersed, who of them would recall the ecclesiastical show, or anything but the image of the unhappy girl who had been insulted before all her friends? And here it may be noted how this mania for displaying rich and gorgeous costumes, instead of aiding, actually frustrates the effects intended. The rule seems to be 
that every one shall wear his gala clothes at all seasons and in every place. A courtier in his private apartment still displays his rich silken robes; the young Italian nobles are ever dazzling in silks and satins and laces and gold embroideries, walking the streets even in a sort of ballroom attire. Exciting events must take place in vast palatial halls, where a great crowd of guests and courtiers is ever at hand to look on.

Benedick is a truly delightful character, conceived in the best vein of airy comedy. But how often is it misapprehended! There should be a tone of artificial good-humour and self-complacency, as though he felt quite superior in his insensibility to the charms of the sex. When he is at last caught by the irresistible Beatrice, he should show a sort of bewilderment, and even alarm. Such a thing should seem actually incredible to him. Miss Terry's performance was really faultless-it was so buoyant, so full of spirit, and so rich in natural touches. Irving was a little stiff, and throughout preserved a self-consciousness, as though he were striving to look more absurd and act up to the ludicrousness of the situation. This was a little shown in the Garden Scene, where his friends were in hiding, watching for him. To the audience all that followed seemed a bit of rich practical joking-a scene of buffoonery, laughter at the expense of a sort of butt. The truth was, they were nobles, well-bred gentlemen, engaged in a serious, friendly little plot to get him married to a charming lady. For what was the situation?

Says Don Pedro:

'I will in the interim undertake one of Hercules' labours, which is to bring Signor Benedick and the Lady Beatrice into a mountain of affection. I would fain have it a match : and I doubt not but to fashion it, if you three will but minister such assistance as I will give you direction.'

No practical joke here, but a serious good-natured plan. And consider the character and position of the parties. Don Pedro was the Prince of Arragon, Leonato the Governor of Messina, Claudio a young lord of Florence - all persons of state and degree, not pleasant buffoons. Governors and Princes do not give themselves away in this fashion. Would not Benedick, too, be scared off by this rough and boisterous raillery?

But here is a puzzle. Benedick had sent his boy to fetch a book. He wished to have 'a quiet read.' He marks that the 
party are coming his way, and would escape. Why? He was not a shy person, but gay and fond of company; yet he will hide behind a tree and listen. Was the place, a sort of cul-de-sac, with only one issue, at which he must encounter them? It would seem so. It was likely enough that after his long talk with himself, in which it dawned on him that he was deeply in love with a piquant lady, he felt instinctively that he would have to encounter some rallying on the subject, and could not carry it off well; this might account for his hiding in the trees. Then, again, how did the trio know that they would find their Benedick in the garden? They had probably met the boy and learned it from him; and, knowing that there was but one entrance to the garden, they felt secure that they had him caged.

Turning now to The Merchant of Venice: Irving contributed a certain original treatment, notably in the case of his Shylock and Macbeth. But interesting as such readings were, there can be little doubt but that the old traditional conception is the true one. The Jew, from the earliest times, used to be represented as a low, furious savage, eager for revenge and blood, greedy for money. Associated with this were a certain grotesqueness-great length of nose, etc.-meant to excite laughter, much as the ways of the stage Jew do at present. Irving, however, conceived the idea of turning him into a gentlemanly, well-bred personage, with a sensitive heart and refinement of bearing. It is obvious that no such character of this kind would indulge in fanatical hatreds-' pound of flesh ' penalty; but it is perfectly consistent with the pattern of the low, hooknosed, money-lending Jew. Could we fancy this gentlemanly Jew, arrayed in his violet gabardine, with persuasive and refined speech, flourishing a bare knife in an open court, and calling on the defendant to be handed over to him to have the forfeit cut from his heart coram publico? It seems a sudden fit of insanity. But if we take it that he is a low pariah-one of the outcasts of Venice-anyone might revile, mock, laugh at, kick, and spit on him even, with perfect impunity. Antonio had actually spat upon the gabardine. It seems more appropriate. Anything might be expected from such an animal, and it must have been received as a good joke, a capital piece of buffoonery. But so deft and popular was Irving in those days that he could 
successfully impose anything he pleased upon his audience; though the judicious might smile or grieve, they did not protest. And the revival was really a performance of surpassing interest and attraction, the decoration and scenic illustrations being kept within legitimate bounds. It might be considered the best of the long series that he furnished us with.

In the Merchant of Venice there was a touch introduced on this principle, which was vastly admired, considered to have brought out the inner meaning of the bard. When Shylock had gone from his house and crossed the bridge, the curtain descended, and after a moment rose again, showing the Jew slowly making his way back, to find his daughter fled. Now, according to the course of the play, no one could know that the daughter had eloped, so that the Jew's return conveyed no meaning. Then there was the short interval, which could not be lengthened by merely dropping a curtain and lifting it at once. The act drop suggests the elapsing of time by remaining down.

This is but a typical instance of a favourite way of dealing with the bard-namely, by developing some trivial or casual allusion made en passant, but on which the ambitious manager will build a huge modern structure, his plea being that it was, as it were, contained or wrapt up in the passages.

I once remember a production of Romeo and Juliet where the quarrel in the street between the rival factions was gradually worked up. This was Lewis Wingfield's idea. All the bells of the city rang out; the mob poured in from by-streets; the guard interposed-it, in fact, became like the great midnight riot in the Meistersingers. This was all proper according to the modern canons of development; but how false was the principle! It was really no more than a scuffle between retainers of the hostile lords who casually met, and it was intended to lightly indicate the relations of the rival houses towards each other; but it developed into a riot and insurrection even. The proportions of the things were absurdly exaggerated, and thus dwarfed the rest of the play.

In the Lyceum revival of Macbeth, Scene VI. of Act I. was illustrated in a truly effective and dramatic manner. It is only a short snatch of a scene, about forty lines long-a mere cloth scene-but the manager had a really lovely picture 
of the castle gate, to which King Duncan approached. It was bathed in the clear air and sunshine, and had an air of welcoming repose which exactly fitted the poetical-

\section{' This castle hath a pleasant seat ; the air Nimbly and sweetly recommends itself Unto our gentle senses.'}

Then follows the description of the martlet nestling in the battlements. There was exquisite art in this, for it conveyed the notes of welcome and innocent hospitality, of rest and recovery after the journey, and with a grateful sleep-all in contrast to the hideous night of trouble that was to follow.

One of Irving's new readings in Macbeth almost took one's breath away. It seemed incredible that so brilliant and sensible a man should have even thought of such a thing. At the end of the first act, Macbeth says to his lady: "If we fail ?' To which Miss Terry was made to reply: 'We fail !' -that is, 'Well, we fail, that's all.' It is obvious that the speech is contemptuous. ' What! we fail! Not likely.'

But how likely that this uncontrolled and irresponsible chief - not merely the head of the whole enterprise, but of the acting also, spending his days in directing his myrmidons, his nights in receiving the exclusive applause of his admirers-how likely, I say, that this should lead to elation, to 'swelling of the head,' to intolerance of criticism or advice, to general selfishness and greed, such as Bottom showed!

We have now grown familiar with that special development of theatrical administration, the actor-manager. This has become the most important element in all modern Shakespearean revivals, and influences all the details. Opinions seem divided as to whether this actor-manager is an abuse or the reverse, but the actor-manager has at least helped to spread the knowledge and appreciation of the bard. If Charles Kean was perhaps the first important actor-manager, there can be no doubt that Sir Henry Irving was the first, most romantic, influential of the modern era. Garrick, though manager, was really no more than an actor in his own company. He played in his turn and when he was required. Macready merely took a theatre for a short term-no doubt to exhibit his own talent to the best effect, and the audience, it might honestly be said, 
attended the theatre to see the popular favourite, and him alone, Phelps's was a regular company of good players.

The modern system, however, is much more personal. The change is really extraordinary. All feel that it is impossible now for a highly popular actor of the first rank to take an engagement at a theatre. It is not spacious enough, as it were, to hold him. He could not be supported properly. The days of the good all-round company-like those of the old Haymarket, when there were half a dozen admirable comedians and farce actors of equal merit-has gone by. What is required now is one central figure with a crowd of figures of a respectable but sufficient mediocrity grouped round him.

The oft-quoted melodious lines,

\section{'As in a theatre the eyes of men,}

When the well-graced actor leaves the stage,

Are coldly bent on him that enters next,'

seem to have foreshadowed the reign of the actor-manager. A leading actor who enjoys much personal popularity cannot, as I have said, find an opening for his talents in an ordinary playhouse, so he is naturally compelled to fix himself in a theatre of his own, running all risks, finding the money, and assuming all responsibility. As his popularity is his chief assistant, it is but natural that he should use this to the utmost by enhancing the central attraction. No one can find fault, for it is the natural evolution of the situation; nothing else is practical or feasible.

The actor-manager system necessarily entails one-part plays, and one-part plays naturally entail the use of cheap and inferior players. It would not do to bring forward first-class meritorious actors, for this would be sharing the applause with another, and so diminishing the central attraction. Besides, the first-class actor would presently be an actor-manager himself. This is not owing to vanity or greed of applause, but simply to the necessity of the system. For to pay the manager must be the sole attraction, and Shakespeare's pieces offer the finest opportunity for such personal display.

But we can see signs of a coming change. The actormanager principle seems to be weakening out, and the control passing to syndicates and enterprising American magnates. Already several highly popular manager-actors, such as $\mathrm{Mr}$. 
Seymour Hicks and Mr. Cyril Maude, are now under the control of societies. There are not more than two or three of the old pattern left, such as Mr. George Alexander, Mr. Lewis Waller, Mr. Bourchier, and Mr. Beerbohm Tree. The more famous actor-managers, besides, generally duplicated their interest by the aid of some popular female performer, often a clever wife.

Before considering Mr. Tree's methods of treating Shakespeare, it must be conceded that no such example of sumptuous and costly setting forth, sustained through many years, without regard to labour or expense, has ever been known in the annals of the stage. The experiment has been a perfectly dazzling one; nor can it have been followed without interest. It is Shakespeare under conditions earthy, no doubt, and levelling, but, still, treated with the utmost skill and intelligence that such treatment will admit of. The manager's steady and unwearied perseverance, his never-flagging ambition, seeking Alps above Alps, deserves the most unstinted praise. It is his Shakespearean principles that cannot be proved or approved.

On the stage not histrionic talent merely, vulgarly supposed to be the one merit, but the valuable commercial gifts of energy, ambition, versatility, knowledge of public taste, variety, are absolutely essential, and have their effect on the public, as they have in other directions. These are the gifts of genuine management. One of the saddest things in Irving's decay was his apparent failure to 'hit' the public taste. Here Mr. Tree is conspicuous, and his indomitable energy and 'up-to-dateness' have contributed immensely to the public stock of harmless pleasure. A really magnificent theatre, almost an opera-house, with superb and lavish appointments for every piece, have made all his performances singularly attractive. In this respect the work of Irving has been eclipsed, and seems now somewhat old-fashioned.

What has Mr. Tree done for Shakespeare? A vast deal, his admirers will say, pointing to the long series of productions by the bard-Hamlet, Julius Casar, The Merry Wives, A Midsummer Night's Dream, Twelfth Night, Richard II., Winter's Tale, The Tempest, and Antony and Cleopatra. Every form of art has been lavishly expended on these pieces. Alas! that so important a matter should have been overlooked as the intelli- 
gent, reverential dealing with the play itself, and a genuine histrionic presentment. It was a pleasing Shakespearean panorama, rather than a dramatic performance. The manager, as was only fair and proper considering his exertions, became the leading figure in all. Yet what single man could have gifts sufficient for all these great and violently contrasted characters? Those who supported him were respectable, but far inferior. It was not so at the Lyceum, where the Irving instinct and romantic spirit was somehow contrived to be infused into the crowd round him. Yet we should all be grateful to him for it. He has made these great productions familiar to a vast mass of the ignorant and careless, and given them a relish.

Mr. Tree is a man of extraordinary brilliancy and cleverness. His energy is superhuman, his designs lofty and ambitious, and carried out almost magnificently. For his ends he built himself a noble, beautifully-designed playhouse, laid out on amphitheatral principles, and more suited than any other house in town for Shakespearean plays. His répertoire of pieces has been amazing for his time. There is no doubt he is as much followed as Irving ever was, and by the younger generation is thoroughly believed in; for no one entertains his audience better or gives better value. The eye is recreated by scenes of beauty and elaborateness, the ear by the Wagnerian strains of Roze and other accomplished artists. His Shakespeare performances, such as Richard II. and Julius Casar, must always gratify even those whose taste is not satisfied. He has secured and trained a sound body of actors, whose efforts give genuine pleasure. One cannot but wonder at and applaud the vast energy, the abundance of details, bewildering almost, which attend the production of a vast piece such as Richard II. But there are many things-instances of bizarre treatment, strange misconceptions, misunderstandings of the spirit, fantastic perversions, comedy turned to farce-which make the judicious grieve. These I propose to consider.

Mr. Tree is unrivalled in the romantic characters of ordinary life. There he is convincing and persuasive, and has all the best French traditions. In his Shakespearean characters he shows elocutionary defects, the most curious of which is a miscalculation as to the fitting tones in which a sentence 
should be delivered so as to bring out the meaning. These become really a series of surprises, the inflexions are so curiously misplaced. His natural voice, too, lacks weight and breadth. It is thin and weak, inharmonious; and often some reply of only two or three words, but full of a pregnant meaning, leaves no impression. But it is in the handling and illustrative treatment of these great plays that he must be criticized. The modern devices of seizing on some allusion in the text and developing from thence some grand show-as Irving did in the case of the Church Scene in Much Ado About Nothing-have been carried to an extreme. His Malvolio at this moment is perhaps more admired than any of his characters, and is really thought to be a surprisingly humorous and diverting performance. In its business, superadded dress, make-up, and comic turns and gestures, nothing is wanting to fend off a dull moment. Yet there is nothing in it of Shakespeare's steward. It is one protracted piece of humour and frolic. Let us consider for a moment what Malvolio is : a serious, almost pathetic character; a grave, dignified, Quixote-like gentleman, in love with his mistress, chivalrous and utterly unconscious of his own folly. $\mathrm{He}$ is a capable person, or he would not have been at the head of a large establishment. In this fashion he has generally been played. Though he was the butt of his companions, this would not make him voluntarily contribute absurdities-tumble, as it were, to add to their amusement. There is no selfconsciousness present.

But take the treatment of the ring incident. He carries a long stick or pole of office, which, when the ring is tendered to him, he extends, point forward, inviting the ring to be placed there, so that it may run down to the handle! There was no thought that for a small ring to fit on a stick of this sort it must be gigantic in its diameter; but at such a piece of business of course there was loud laughter. Neither was there any thought of the improbability of the love-sick steward treating the august ring with such disrespect! He would naturally receive it with a tender reverence. But what was this to the habitual entry of the steward, who came on always and went off always attended by, I think, four followers, nicely graduated in size-tall, less tall, so down to actual short. These walked after him in step, making grotesque antics to a 
truly comic march, he also stepping out in time and in a facetious way! It was true pantomime. This also, and naturally, produced roars of laughter. But the only wonder was how such a notion could have been conceived.

Bottom, the weaver, was another odd perversion. It was distended till it spread over the whole play. The result was a lack of proportion and disturbance, the rest being dwarfed in consequence. Here is a great danger in Shakespearean performance, where what is merely a passing incident is fashioned into a structural and important portion. There was a signal instance of this in the case of Miss Mary Anderson's revival of Romeo and Juliet, where the nurse was taken by the admirable Mrs. Stirling. So excellent was her delivery, so important and weighty her creation, that she really overshadowed the whole play. The others seemed flat and poor by comparison. It is obvious that to have a nurse of this immense talent and capacity would seem unnatural and unfitting. When the clowns in $A$ Midsummer Night's Dream were assembled to rehearse, Mr. Tree had a prodigious 'entry,' going round to each of his fellows and allowing them to take his hand in an idolizing way. The actor's voice is too thin and piping for such a character. Bottom should be a coarse, bull-necked fellow, with a rich and strong voice, able to ' roar you.' There was the same weakness in his Falstaff. But the drolleries of Bottom and his fellows are always unduly exaggerated, particularly in the scene of the performance where there are familiarities and buffooneries which are inconsistent with the respect due to a Court. Then the awe and nervousness of such a company of tradesmen are quite forgotten, and they seem all at their ease. How much more natural the effect would be were there a certain earnestness and gravity present, as though each were striving to do his best! There is another danger, too, in this exaggeration-that of destroying the proportion and giving this comic element too great a prominence.

And yet, though all this makes the judicious grieve, it cannot be denied that Mr. Tree is an admirable and most judicious actor in his own line-yea, even an admirable Shakespearean actor. Nothing finer on the modern stage has been witnessed than his performance of Mark Antony in Julius Casar, where his speech to the crowd was intensely dramatic-simply masterly. 
He swayed it, played on it as if on an instrument, inflaming, soothing down. 'O si sic omnes!'

Leading actors usually make choice of a particular Shakespearean character because such happens to suit them. Mr. Tree, however, greatly daring, seems ready to essay any in succession or all. We may admire this intrepid spirit, and he may be right, from his point of view; for as he always treats his play as a gorgeous spectacular show, this does not so much matter, and all shortcomings are covered up. He really gives us a series of excellent recitations, but he scarcely can be considered to act his great characters-that is, fill them out-or offer those moods and hesitations and sudden changes, and all that fascinating gamut which makes up true acting. Richard II. is stored full of speeches-very long most of them-and our manager recites them with infinite pains and good elocution. As each speech comes round, he composes himself for the effort, and delivers it fluently and correctly too, but without much heart, passion, or feeling. But, indeed, most of our actors recite in this way, conveying that they have the words by heart.

For Caliban there is but the one traditional way. As he is set down in the text as a half monster, repulsive and hideous in aspect, so he must be represented as physically repulsive and hideous. Mr. Tree went to great pains to produce this impression. Now, as I have shown, a quiet, unprejudiced study of the part will show that there is nothing specially horrible or monstrous about Caliban's aspect. There is no need of his being disfigured in this fashion by the property man. The true mode of interpretation would be to show him as mentally repulsive and ugly. Prospero does so effectively before Caliban appears on the scene. He must act repulsiveness-i.e., show suspicion, hatred, meanness, etc.-so that we may exclaim, 'What an abominable creature this is!' The result will be far more powerful than anything through the agency of fangs, false nose, etc. So with his grovelling, when he creeps from his cave like an animal and crawls to Prospero. What is forgotten is the suffering side of the creature-his piteous complaints of tyrannous treatment. If this were more brought out, a sort of sympathy would be excited. He suggests the treatment of some animal by a brutal master. All the low, savage element has been exaggerated by the performers. 
Would the magician, we maylask, need to exert his tremendous power in the case of so low and degraded a thinga sort of brute breast? No; Caliban must have been a rebellious and fallen spirit. He therefore, as I have said, offers a rather tragic spectacle, and should excite sympathy.

For one revival at least Shakespeareans are deeply indebted to Mr. Tree-viz., for the almost fascinating Richard II. One is inclined to regret that Irving had never taken up this play. It was certainly suited to him, and he would have made it pathetically interesting. On the other hand, he would have been as slow as Mr. Tree, if not slower. Alas! when will our actors learn that people in agitated situations hurry their utterances more quickly and excitedly, and pour out their words? There is something truly fascinating in the tone and subtle exhibition of divers mental states in this great character -now dreamy, now piteous, alternated with scenes of violence. One is astonished that it has never taken firm hold of the public, and it is to be feared that it rather goes over their head, and is too refined for its appreciation. Mr. Tree may be forgiven much for his admirable presentation of this interesting and, attractive piece. Nothing, indeed, could be better or more exciting as an entertainment. Here we may certainly condone the various decorative adornments, processions, and the like, which seem almost legitimate, as, for instance, Bolingbroke's triumphant entry, first introduced, I believe, by Charles Kean. Shakespeare, indeed, by the mouth of his Chorus in Henry V., tacitly bids us invite our imagination to work and supply the scene; but, though not set down, we may fairly assume that it is implied.

In the scene of the entry to London there was, of course, almost a squadron of horses engaged, who took some time to pass in the vivid procession through the scenic street. A most effective business it was. But the most notable moment was the appearance of the wretched King, agitated, sitting uneasily upon his beast, and clearly conveying that he was led captive. Mr. Tree's bearing was truly dramatic and significant.

This is the play of long speeches and dialogues-speeches and dialogues of an intricate sort, almost metaphysical in parts, and so requiring delicate inflexions, due emphasis, and clear intona- 
tion to bring out the meaning. Here the manager presents the aspect of a hapless King, after a poetical fashion.

As we know, Richard is a changeable, hesitating character, fitful, uncertain, yet all the time positive and apparently determined or self-willed. It is clear that all this uncertainty of character should be distinctly marked in the early portions, which prepare us for the later ones. How uncertain, for instance, is his behaviour to the two angry Lords Bolingbroke and Mowbray! He cannot make up his mind what to do with them, and so drifts into the tournament arrangement. It is worth considering on a moment what a penalty has to be paid for too much realism. Nothing could be better or so good as Mr. Tree's exhibition of the lists-the crowd and all the ceremonial. It was admirably delusive and perfect. But, as we know from the play, it did not go beyond the prefatory ceremonials. When the King threw down his baton and stopped the conflict, the feeling in the audience was clearly aware that all this pomp of lists, crowds, shoutings, etc., was thrown-away effort, and scarcely intelligible. The King sat aloft in his 'pen' through all the heraldic programme. When an official says, 'Stay! the King has thrown down his warder,' he then in a rather unmeaning fashion proceeds to sentence the two lords to banishment. In all this there was shown something indistinct. The changes were not brought out as they should be. Let us see.

It may be conceded that this passage more completely than any other in Shakespeare warrants the scenic development of the lists, tournament, etc.; but it may be doubted if the arrangement of the stage here is exactly what was intended. This exhibition of galleries or boxes, the setting the King and his Court afar off and aloft, excludes acting. I always think that there never should be a stage on a stage, and that words and acting on the second stage become ineffective.

How, then, should it be done? The situation is this: The irresolute monarch has been drawn in to consent to the conflict, yet he is displeased and fretted that his proposals for accommodation have not been accepted by the masterful Bolingbroke, whom he mistrusts. Then he suddenly makes up his mind to stop the business and get rid of both. The lists should be placed without, and the King go to the wing in a 
marked ostentatious fashion to cast down his warder. By this arrangement we have the whole business acted, and not exhibited.

That the throwing down the warder, too, is described and not seen is proved by attention being called to it. We could imagine the King making excited gestures, waving his arms, with attendant confusion, surprise, etc., in the spectator. But we are astonished to find, on looking at the text, that the whole was arranged in a much more business-like fashion. The severe sentence was the result of a sort of improvised council, the King saying :

'Withdraw with us, while we return these dukes what we decree.'

After a few moments he comes forward and says :

'Draw near and list what with our council we have done.'

Mr. Tree, of course, with his pens and pent-houses, where the King was 'on view,' had to leave out all this.

The death of the King is represented as a sort of violent scuffle or riot, and we can hardly see how the King so suddenly attacks one of the attendants. Then enters Exton, with others, and a second 'shindy' sets in, during which no words are heard and little is seen-it is so dark. Yet the whole, when understood from the text, is quite distinct, deliberate, and most interesting. The forlorn King has been talking with the faithful groom about his horse Barbary and about his wrongs, when a keeper enters and bids the groom get away; on which the King shows a fretful agitation, and even fury, walking about angrily until the keeper bids him sit down to his meal. On which the King shows mad suspicion, and hastily insists on his tasting it, which the other refuses, as it has been forbidden by Exton. The poor King, half maddened, gets in a fury and beats him. Exton and his men enter the next moment. The King at once divines that they have come to kill him-as, indeed, they have-and, snatching a weapon, attacks one of the men, killing him; then attacks another attendant and kills him, on which Exton 'strikes him down.' During this struggle there are words and speeches which ought to be clearly heard. When the King is lying dead a sort of vision or phantasmagoria follows: the walls of the prison disappear, 
and the Coronation Scene in Westminster Abbey is shown, with processions, music, etc. The idea seems to be that the King has some dim vision of this kind, but it is quite too pantomimic, though certainly effective.

By this arrangement it is conveyed that Bolingbroke had contrived and ordered the King's murder. Exton persuades his comrade that Bolingbroke had asked for some one to rid him of this enemy, but he was speaking of another. In place of this coronation show there is a scene where Exton brings in Richard in his coffin.

Mr. Tree's last effort has been the splendid Antony and Cleopatra-that gigantic play. Alas! for that incurable love of the panorama, which is to this play, of all others, repugnant; for the piece is made to open with an elaborately-painted view of the famous Sphinx in all its solemnity. Nothing is done in presence of this Sphinx-no performers appear-but the audience is invited to gaze on it for a few moments, when it passes away. At the close, after the tragic work is done, the Sphinx reappears, and the audience is again allowed to moralize in its presence. The point and meaning of this intrusion is officially explained.*

Few producers have been able to resist the introduction of the noted Cleopatra's galley, so gorgeously described by Enobarbus, with its burnished gold; and one dreads, it must be confessed, these galleys-propelled over the floor on rollers,

* Expounding his intentions to members of the Press, Mr. Tree continued to dwell earnestly on this intruded device of the Egyptian Sphinx. "The major part of the drama is laid in Egypt, that wonderful civilization which has been for some centuries buried beneath the sands of time. There remains through the centuries the calm figure of the Sphinx, still gazing across the desert of to-day, as it did in the days of Egyptian greatness; so I propose at the rise of the curtain that this symbol shall be the opening note of the play. At the close of our falling night we see looming once more through the darkness the calm, indifferent figure of the Sphinx in the desert. The play ends as it begins, with this symbol of eternity.'

One may speculate vainly as to how this is connected with the play, or how the placid indifference of the Sphinx can have aught to do with the tempestuous movements of the drama and its personages, which are not in the least regulated by fate or destiny. Is it disrespectful to say that this approaches clap-trap? It is as unmeaning as it is un-Shakespearean.

There is no reason why this principle should not be applied to other plays of Shakespeare. In Macbeth, for instance, some old Scottish monument might be exhibited at the opening and at the end, as 'symbol of eternity looking on with calm indifference through the ages'; and so with Hamlet there might be an old Danish relic portrayed. It is a purely fanciful and even unmeaning notion. 
the linen waters coming up to the footlights, which they are prevented overflowing by a long board, which is yet no bank or shore, but a clumsy method of terminating the enclosed area.

Shakespearean ' revivals,' as they are called, have always been in high favour, from the days of Garrick to those of Mr. Beerbohm Tree-' revival' being presumed to stand for costly and elaborate adornments in the way of dressing and decoration. Each 'reviver' strives to excel his predecessor in the sumptuousness of his 'show' and the piece selected is usually as much burdened, and even overwhelmed, with trappings as was the Tarpeian maid. The outlay is almost reckless. The superficial crowd, no doubt, thinks that this system is a proper and legitimate way of illustrating the text. To tell them that the greater and more lavish the decoration, the less must be the intelligence, with an attendant certainty that the meaning of the words and significance of the action and characters will be obscured, might seem to them fantastic and paradoxical; and yet it is the truth, for a Shakespeare play unadorned is adorned the most. In such displays the proportion is destroyed. What is meant to be airily touched is overwhelmed, as in Mr. Tree's gorgeous presentation of the Twelfth Night where we are shown the beautiful gardens of the lady, so elaborately laid out as to bring us. down to the world without.

Elia's well-known essay on 'Shakespeare's Tragedies' holds within it the correct principles that should guide the Shakespearean reviver. True, we find the rather fantastic and extravagant theory that the plays should not be acted at all, as this process, he contended, brings down both performers and audience to earthy depths, and destroys the work of the 'imaginative faculty.' But the theory might be amended into this : that the reader has a greater enjoyment and appreciation than the spectator, which is certainly true. He also maintains that we always confound the player with the character. You see Kemble or Irving before you, rather than Macbeth or Shylock. 'So to see Lear acted,' he says- 'to see an old man tottering about the stage with a walking-stick, turned out of doors by his daughters on a rainy night-has nothing in it but what is painful and disgusting. The contemptible machinery with 
which they mimic the storm into which he goes out is not more inadequate to represent the horrors of the real elements.' It is easy to apply and extend this to the principles we have been considering, which prove how impossible it is, on the stage, to supply an illusory reproduction of the things of real life. The nearer the representation approaches to the mere conditions of the reading, the better it will be; while scenery and appointments should be supplied, subject to modern rules, by the characters and the interpretations. It is hopeless, of course, in these days to attempt to turn back the tide. The stage system of painting, lights, dresses, upholstery, etc., is too firmly established to be reformed or abandoned. Granting, however, that we must continue to accept them, we may contend that even these accepted methods are, in their way, most rude and unintelligent, and that if managers sought an inspiration, and permeated themselves with the true Shakespearean spirit, they could present their show in a far more plausible and rational fashion. But no! they cling to the old trucs, covering them over with modern tinsel. Nor do they seek for the Shakespearean illusion, the lifting of the spectator into the realms of fancy and into the spiritual land. All is gorgeous, but mechanical and earthy. All stagecraft and tradional devices, tricks, etc., should be subordinate. Any attempts at stage sensation, realistic treatment, should be taboo.*

* Mr. Sidney Lee witnessed a performance of Antony at the Hofburg Theatre in Vienna which occupied five hours, and no one seemed fatigued or to lose interest. I fear we in this country have quite lost the studious intellectual taste which could help us to sit up through plays of Racine, or Lessing, or Schiller, or Goethe, as all cultivated nations are trained to do. This is a serious matter, and should make us pause to think. We know that no manager dare present here a five-hour play. 


\section{CHAPTER V}

\section{OTHER MODERN REVIVALS}

D ESIDES Mr. Tree's great panoramic efforts, there have $\mathcal{B}$ been a good many representations at the smaller theatres of a less pretentious kind, and which by the conditions have given greater prominence to the acting. Some of these have been of considerable merit and interest.

Among these conscientious directors the foremost is assuredly Mr. F. Benson, the earliest pioneer of the system, who for years has held on steadily in his course, never flagging, and leading his répertoire company into every part of the kingdom. How excellent his methods-beginning with a perfectly practised company, well trained, and advanced hierarchically through all the degrees, supported by a modest but sufficient decoration and dressing, an intelligent arrangement of each play! His pieces are set forth with a correct and judicious reserve in the setting; everything is suitable and handsome, but nothing in excess. But the chief praise must be for the sound, excellent, and solid acting. Every one is trained, all play together, and say their speeches with an admirable elocution that recalls the ' good old school.'

At the close we feel that we have been witnessing a most thoughtful and suggestive performance-one that can be called satisfactory. The manager himself usually takes the leading character, and, it must be confessed, has some peculiarities which one could wish away; but these are overpowered by his entire sincerity and ardour. This Benson treatment has become a system. We find his scholars in all the companiesnotably Mr. O. Asche and Miss Brayton-where they are revealed by their admirable and special training. But, as I said, we owe a debt of gratitude to him for this increase of the public stock of harmless pleasure. 
Yet another of these conscientious and thoughtful workers, still, without any pretension or showmanship, is Mr. Otho Stuart, of the Adelphi. We are indebted to him also for at least a couple of intelligently managed revivals, which have been heartily enjoyed and can be favourably compared with the most sumptuous attempts. Nothing could exceed the good spirits, the simplicity, the animation, the 'go,' as it is called, of The Taming of the Shrew. It was 'natural, easy, affecting,' as was said of Garrick, and also unaffected. One can see it many times with pleasure and interest. The performers were unambitious; they had not been schooled down to inanity, or oppressed by the overpowering presence of an actor-manager; nor were they afraid to be spontaneous, lest they should interfere with the effect of costly and elaborate scenery. There was due reserve in scenery, reserve in dresses, and consequently perfect freedom for the characters and the play.

One of the happiest features of the whole was the way in which the tone of the Italian life was brought before us. All the portion that dealt with the suitors, who were bidding, as it were, for Bianca, seemed most natural and had a great interest, contrasting also with the humours of the shrew and her 'tamer.' These gracefully decked youths passing to and fro, the crafty old father-all fell into their places, moved gracefully, and made pictures like one of Paolo Veronese's. Something in the elocution, of course, was wanting, the recitation of the lines imperfect, and much, therefore, as is usual, inaudible. All was spoken as though it were common talk of our day. This, however, could be helped, cannot now be remedied. The conception of the pleasant scenes with Bianca, with the tutor and music-master, etc., was rather common farce-a good joke or bit of humbug. It should have been put on a higher level, and treated with comedy grace and elegance; the young men lovers, etc., should have walked with an elegant and stately grace, like young nobles as they were. But, alas! our young performers can hardly do this, nor can they be expected to do it. There should be music, too, in their voices.

It is unfortunate that the comic portion of The Taming of the Shrew should always have been considered the essential part of the play, all the rest being abbreviated, cut out, and generally maltreated. It is, in truth, only intended as 'relief' 
to a pleasing and interesting comedy. Even if it stood by itself, the plot is developed at good length and lightened up in the most delightful way by the Shrew Scenes. It might well stand alone.

In The Taming of the Shrew it invariably happens that there is a sad exaggeration in these 'rough-and-tumble' scenes. They are gone through in pantomime fashion. Petruchio throws about the sham meat, dresses, etc., exactly as in a pantomime. The cooks bring in their 'property' leg of mutton, which he flings away, and they rush off, tumbling over each other with an unconvincing pretence of terror. So with the dresses, band-boxes, etc., brought by a milliner-all pantomime. But, it will be asked, how should it be done? In a natural and realistic way. The cooks, whose work was so rudely tréated, would be more surprised than terrified; they should show astonishment, pick up their joints ruefully and with some indignation. Petruchio should be more deliberate, as if gradually working himself into a fury. As Johnson, criticizing Garrick, said, he should let 'the gentleman break through the footman.' So should Petruchio let his goodhumour break through his pretended rage. For here was an Italian carrying out a plan for the subjugation of his ladya serious but important business. He would say to himself, 'I must awe this woman-thoroughly frighten her out of her life.' But instead we have only a comical personage throwing about legs of mutton and tearing up dresses! And all done in a moment. No wife would be frightened by such a proceeding. No; the actors should take thought, strive to visualize the situation, and always put this question to themselves: 'Of what sort would this situation be in real life? and how should I behave in such a situation?'

Then, again, in such a play we may always note the literalism that regulates it. Everything is interpreted in a matter-of-fact English way, without a thought for the Italian atmosphere. The joinings are too rough. All should be blended and softened; scene should succeed scene in a dreamy way. The actors should try and try, and feel the soft Italian persuasiveness joined with impetuousness. And then the stately gentlemanliness, the air of gracious courtesy, with melodious tones-where are we to find that? But no; comic business 
has to be got out of passages like the music-lesson; where the supposed professor was sat two clowns at horse-play, and two Italian gentlemen trying to outwit one another. The shapers and adapters of the bard have often played fantastic tricks with the play. When Sly is found asleep, and carried off by the Duke's orders, we next find him in bed in a sumptuous chamber, waking up as from a dream. There is no warrant for this in the text, for we are told, 'Enter Sly, with attendants.' No doubt the discovery in a bed adds somewhat to the 'comic business,' but, still, it is not set down. A more serious omission is the introduction of the players to the Duke, who are instructed by him as to the acting of the piece that follows-a significant illustration of the social status of these people, who could be made by the nobles to take part in rude practical joking. This is necessary as explaining how the play came to be performed. It brings us also to the great difficulty which has puzzled managers, viz., how it can be contrived that Sly should witness the play, it being performed in his presence. Sometimes he was placed in a chair at the wing, but the true solution is to assume that he was, as it were, present invisibly. But here is a suggestion that might be worth considering : What if, at the close of the induction, a scene were exhibited representing the interior of a large chamber, with a stage fitted up at one end? Then a pompous and grotesque procession, introducing Sly, who was shown to the principal seat, the music striking up, while as the curtain rose the scene would close in. The notion of Sly and Petruchio being performed by the same actor destroys the relation between the two portions of the play; it is most intolerable, and not to be endured.

A beautifully 'staged' revival of this play was that of the late Augustin Daly, in which Miss Rehan and Mr. Drew were the leading performers. Interesting and attractive as it was, it seemed to me that the Adelphi version was better. Drew was not much of a woman-tamer; his voice was not strong, he was too genteel. Miss Rehan was admirable, but still hardly coarse enough. One could not ask a more satisfactory performance than that of Oscar Asche; he has the voice, the roughness, the build by nature-a very carter of a man. Miss Brayton was also excellently suited to the part, and they made an admirable pair. As she performed the two characters of mother and 
daughter-Hermione and Perdita: the one tender, plaintive, and loving; the other bright and animated-the contrast was wonderful. Nothing excited more interest than the abandon of the rustic dance, through which the young girl literally bounded with an enchanting exuberance. And then the Statue Scene. How tender was the revelation and the slow descent of the steps, all watching, absorbed and dazed, as it moved. Perhaps, on the whole, this was the most poetical of all the revivals.

The propriety of 'doubling,' as it is called, of the parts of Hermione and the youthful Perdita may be questioned, as it destroys the significance of each character. It was impossible to see the girlish Perdita frisking it and dancing without recalling that she was also the wise and mature Hermione, and there was something almost comic in the thought that the faithful, endearing wife was to dwindle away into quite a new shape. To true Shakespeareans there is something disagreeable in the notion. But, then, the opportunity for business: the clever actress can here have compensation for the comparative effacement of Hermione by turning herself into her own daughter! But see at what sacrifice! In the last beautiful Statue Scene one of the tenderest portions is the affectionate bearing of Perdita. Leontes' delight is one thing, the daughter's another; but this latter portion, as a matter of course, has to be ruthlessly cut out, with infinite loss.*

* With this performance we turn to Mr. Tree's elaborate treatment of the same play, in which he appears to have attempted to bring the scent of the haycocks over the footlights.

The rustic scenes are more in the Watteau vein than in that of the riotous, gymnastic, and noisy gathering of English country-folk, who in modern versions invade the stage. Farm labourers, however, joyous and even though in anticipation of a feast, do not come in tumbling, jumping in the air, and roaring vociferously. Perdita is bidden to welcome them :

\footnotetext{
'See, your guests approach.

Address yourself to entertain them sprightly, And let's be red with mirth.'
}

Much grace and measured speeching at this welcoming follows, which would be totally out of keeping with a tumultuous and disorderly gang of yokels. The author is careful to mention the elements of which the visitors consisted-shepherd, clown, Mopsa, Dorcas and two others, with servants. There was a superior distinguishable class, therefore, with a few 'farm hands.' These surely would be quiet and respectful. Then follows a dance by shepherds and shepherdesses, not intended as a sort of confused romp, but a regular measure, headed by Florizel and Perdita, whose presence would 
Mr. Oscar Asche is a fine solid actor, with a full, weighty, and well-cadenced voice, and judicious methods. He is satisfactory in all that he attempts. He is also Shakespearean. Entering on management, he has already given two of the bard's plays-As You Like It and Othello. In this last the spirit of the author and of the piece was a good deal present. In the former, however, it was missed. The fatal literalness seemed to be always present, there was lacking the light fanciful touch, the half-purpose, the indistinct region between jest and serious, which is so attractive. $\mathrm{Mr}$. Asche has the art of giving the full meaning to a mere word or two by a judicious inflexion and a certain intensity.

The ordinary colloquial style of conversation was never so completely applied as in the late revival of As You Like It by Mr. Oscar Asche. The idea, no doubt, was that, as there was a pleasant tone of irresponsibility, of almost picnicking in a forest, it should be all as modern as possible. Accordingly, every one chattered on, hurrying the words, and illustrating all with modern gestures and facial expression. The result was curious-all the play became quite let down to the very 'bass string.' But he was only following the mode.

Rosalind, it need not be said, is the most exquisite of characters : all grace and elegance, with a surprising lightness of touch-now serious, now gay; now only half in earnest, shy and yet bold-a mixture of the most complex feelings, fitful and yet heroic. But this half earnestness is the chief note. In appearance she should be a graceful, elegant creature : her face full of a bright intelligence, her dress inconspicuous, her head unencumbered with wrappings, and her speech ? Nothing said with deliberate intention, nothing frivolous, the delicate poetry being voiced with a tender delicacy and melody. There, as Elia said, 'earth touches heaven.'

Miss Brayton was a very pleasing but practical young

certainly enforce a sort of restraint and decorum. Presently the twelve herdsmen, carters, etc., come in-'men of hair' - and they give a regular formal exhibition of dancing.

But what had this real water to do with us, or we with it? or, above all, where did Shakespeare- Oh, well, " it was all in the picture, you know.' It leant a glamour of poetry; but it seemed to me a disturbing element ; its trickly babble distracted. We wondered what became of the water, why it didn't overflow, etc. Why not a haycock? But who cares for such things? I really believe a fair, open stage, without any of these steps, sham mosques, sham rocks, would look far more real. 
person, heavily and richly attired, a sort of stately personage, with a fantastic head-dress. Her talk was modern. Again I say there is no fault to find here, for she was but following the system.

A certain deliberateness and clearness of utterance, with also a melodious tone or chant, is surely necessary for the delivery of exquisite poetry. There should be also a faith and earnestness-say persuasiveness-in the meaning. This meaning should also be well thought out. Melody, grace, intention -these things should all be present. But where are they to be found without schooling? The truth is that, as the scene and its decoration is a stage above the prosaic audience, so the language and its tones should also be on a higher plane.

The character of the melancholy Jaques is obviously intelligible. There is something pleasing in the notion of this grave, reflective man, who has seen the world, making his wise comments in this sylvan solitude. He is superior to his situation and knows more than his companions. Mr. Asche made him a rather careless personage, in a sort of rude gaberdine, munching apples. The player makes him strike in, after a most familiar easy-going fashion, with the notorious speech, 'All the world's a stage '; as who should say, 'My dear boys, the world is all a piece of acting - everybody goes on acting. Why, the child acts,' etc.

The notion is a rather plausible one, but I think it will not hold; for it must be borne in mind that it is a regular homily and preachment, elaborately and deliberately set forth, the rest listening with immense interest. It takes a long time to develop the theme, which hardly suits mere colloquialism. I believe the true method of delivery would be this: It should be a sort of rumination, in low tones, growing as it went on, each age suggesting the next. Hence there would be pauses as he reflected and new ideas came to him; then he would increase in intensity. There would be a cast of poetry rise from the seat of solemnity and pathos which held his auditors.

The truth is, the theatrical idea was the Duke's own, who had made a remark that there were woeful pageants going on in the world outside the scene in which they were now playing. On which text, the wise man said quickly: 'Why, all the world's a stage.' And the word suggested a stage terminology 
exits, entrances, many parts. Seeing them attentive, he will go on, after a slight pause. But he must be dramatic, and even eloquent, to answer expectations, and so proceed to give pictures of the seven ages.

The historical plays are thought to be dull and dreary, yet I firmly believe that if, full as they are of battles, wars, and confusion, they were taken in hand by capable, thoughtful, and reverent persons, they could be galvanized into perfect interesting life. The meaning of each scene should be sought out and evolved. We find a Legate or an Archbishop and some lords discussing matters, and the recipe is to have some inferior players to recite the long speeches: 'get through' them anyhow-quite a drawing business. Every scene in life can be realized, or visualized, if we only properly project ourselves into it.*

Another most satisfactory and unobtrusive of these modern revivals was Mr. Lewis Waller's production of Henry $V$. It had a slight tinge of modernity, but on that account became interesting. The battle scenes, sieges, etc., were not unduly developed and garnished, but on that account seemed natural and effective. It was conveyed to us very clearly that those eccentric beings, Pistol and the others, were not introduced for comic effect, but were enlisted soldiers, who were enlivening their duties with their oddities and disputes. There never was a better or more intelligible Pistol than Mr. Mollison. Then there was the Chorus, made, as I have shown, a perfectly natural portion of his action and helping it on.

Another very pleasing revival was that of Measure for Measure, a piece one is accustomed to find put aside on the plea that it is impracticable, and unacceptable to audiences. I think all thoughtful people must have been interested by it; and I really believe, had Angelo, Isabella, and Claudio been performed according to Shakespeare's canons, it would have been powerfully attractive. Not but that Mr. Oscar Asche and his wife discharged excellently, but the reading was on simple conventional lines. Angelo, the deputy, became the regular

* I have in this book referred already to an illustration drawn from Meissonier's picture. There seems to me always a lesson in the art of visualizing things. I never pass the etching shop windows without being riveted by that magical ' 1812 ,' Napoleon riding at the head of his Generals. The artist thought it all, firmly fancied he was present. 
stage villain-the tyrant, the man of broken faith, who loved to beguile and shed blood. In this view he becomes an unmeaning personage, and his breaking his promise to Isabella after she had, as he supposed, yielded to his wishes seems wholly superfluous. But it is not simple as this: for Angelo is a strange mixed character of different moods-now winning and persuasive, now fierce and impetuous and savage, now crafty, like Iago. So with Isabella, who is a grand heroine, and playing loftily for a great stake-her brother's life. I could fancy great actors letting themselves be drifted to and fro by the gusto and humours of their passions. 


\section{CHAPTER VI}

\section{SHAKESPEAREAN 'BUSINESS' : ITS NEGLECT AND THE REMEDY}

$\mathrm{S}$ it is certain that the modern devices of stagecraft, with
the time properties, limes, etc., will be always with
us, and must be accepted, we may well wonder why scientific
rules, thought, and study are not applied to their regulation. For there really is a science in all delusion. How complete, how deft, how neat is the common necromancer! Yet on the stage operations are clumsily carried out by 'rule of thumb.' Thus, a bank is required : a sort of box is brought in, covered over with a painted cloth, and you have a bank. Even in carrying out Shakespeare's 'business' the same crudity is shown, yet there can be no doubt these innumerable passages, if dealt with thoughtfully and according to the rules of illusion, would enormously aid the plays. I propose to deal with this interesting topic, and to show by a selection of familiar illustrations how these minor bits of effect ought to be dealt with.

It is wonderful how simple the process of treatment would become if the revivers and organizers set themselves thoughtfully to consider how the situations would appear in ordinary life, and how real people would behave under such conditions. Instead, however, little is thought of but the exhibiting of panoramas of dress and painting and machinery, with the result that nothing is shown that is natural or probable, or, indeed, anything that is familiar in the round of daily life. This appears from an illustration in painting. Every one knows the extraordinary charm and attraction that is found in Meissonier's work. His subjects seem but homely and triviala reader, chess-players, a tavern quarrel, a village sign-painter, and, above all, military and Napoleonic sketches, and yet each has a living, dramatic power of reality that quite captivates; we 
seem to be looking at something living and in action, as though one were at a window gazing at what is going on in the street. Hence the constant uninterrupted stream of etched reproductions, which are almost as much sought for as the original, and fetch $£ 30$ or $£ 40$ a piece. Who can forget the figures of Napoleon-the ' 1812 ,' now riding at the head of his Generals, now solitary on his white horse, now witnessing a charge of cavalry? There is no 'splash' or composition of figures, but, so perfect is the propriety, we feel a conviction that so the great man must have looked in such a situation. Now, what is the reason of this magical effect? It is really owing to an imagination of the most vivid power. The artist saw the situations before his eyes, or he had seen something like them in real life. There was no grouping of paid models and dressing up, though these things came later, when the whole was fixed in his mind. Take the 'Examination of a Peasant,' who has been stopped by a company of soldiers, and is being interrogated by the officer as to the route, etc. Nothing can be more like life. The artist called up the scene before him. He imagined how the soldiers would look and behave-their quiet curiosity ; the gravity of the officer; the vulgar, stolid peasant telling his tale. So with the two mounted officers in another picture, one of whom is pointing out something at a distance. We never forget those two figures, and wonder what it was exactly they were interested about. All which is the result of imagination and knowledge of life, and of how things occur in life-imagination joined with observation-and the artist's imagination excites our imaginations. Then his costumes, mostly a couple of centuries old, not fancy dresses fitted on paid models, but looking as though always worn, and quite familiar to the wearer.

Now, this is the sort of gift and treatment that should be applied to Shakespeare on the stage. Instead of the prosaic imitation of earthy objects, the imagination should be at work ; the reviver should be a seer and have visions. He should ask himself, How this thing would occur in our day? how would persons act in such situations? The manager takes pride in the sheen and glitter of his brand-new dresses-their gold, silver, jewels, and dazzling tints; the costly silks and velvets-all steeped in enriching floods of electric light. All the young men 
and women, gay courtiers, and the rest make a glittering show, which, however, is like nothing in human life. At no court or festival is such an exhibition ever seen. There is no such amount of illuminated life at courts, nor has there ever been exhibited this display of particoloured elements. There is always contrasted light and shadow. The fancy ball seems to have been always the model, though the fancy ball is itself modelled after the stage pattern.

I shall now give some illustrations of the coarse, careless fashion in which the sense and purpose of Shakespeare are invariably distorted. We know the established treatment of the 'fat knight' when he is induced by the 'merry wives' to hide himself in the basket. This seems the receptacle for the family clothes 'going to the wash,' a thing of usually moderate dimensions, but which by a legitimate exaggeration might be enlarged so as to hold Sir John, though not his superadded bulk. The truth is, Falstaff is not intended to be exhibited as a sort of Daniel Lambert or prodigy of flesh. He was the 'fat knight,' corpulent, unwieldy, and of the average bulk. He was a soldier, and fought in the wars. As regards voice, Mr. Tree had to assume a sort of hoarse, guttural croak, which must have made his audience uneasy, as being distressing to the performer. What do our moderns? An enormous basket or chest is seen in a corner, about 7 feet long by 4 feet deep, that would hold the washing of half a dozen families. Then this process follows: The knight is put in ; a couple of porters are introduced carrying poles, which they pass through loops contrived at each side of the basket, and so carry him away-a serious burden. This exhibition is artificial, and out of Nature, though it produces laughter. We cannot help speculating how or why this basket became furnished with loops, or whether the porters called every week with their poles for the family washing. No doubt it is stated in the text that they were specially engaged for the job, but still one cannot help thinking that the ladies had the loops attached for the occasion. It is rather humiliating to have to discuss trivialities so seriously, but a real principle is involved. A shorter and shallower basket should be contrived, with a trap beneath it through which the knight might descend. There should be no poles or carrying in sedan-chair fashion. The porters should drag or half lift the basket towards the 
door, and so out. In fact, a comic effect could be produced by all helping, pushing the basket along, the ladies in screams of laughter thinking of the old fellow within and his sensations.

What is to be the exact hue of Othello's face is always a difficult, but certainly not very important, question to settle. Still, we must make election if his tint is to be ebony black or copper or yellowish. Immaterial as the point is, the protagonist actor must choose and come to a decision. I fancy he will heavily weight himself if he decide on the darker tint, for there will be no room for display of expression of rage, jealousy, etc., and there will be a sustained revolt against the taste of the fair Desdemona, all wondering what else she could expect when she united herself to 'a dirty black.' And yet, after all, the traditional 'coal black' seems simpler and truer; it looks as though carved in ebony. Anyone that has seen the noble figures of the East, their snowy robes contrasting with their faces, could not imagine anything repulsive in the spectacle. Such were the dervishes of the Soudan, those terrible champions whom it was impossible not to respect and stand in awe of. I wonder that this imposing and striking guise had not been thought of ; it is so simple and effective, the contrast between white and black being so marked. Instead, the star player thinks of rich robes, embroidered in gold or colours, with an unbecoming turban.

The Balcony Scene in Romeo and Juliet, so called, was to be regulated by this important scenic principle. On the early stage the spectator supplied the balcony from his imagination-nay, did not want it; the lover and his mistress carried on their sweet converse just as well. But let us see the objections to the existing system. A balcony-and it must be high, so as to be inaccessible to the lover-would be half-way up towards the sky-borders. The lady would be in the air, and have to scream down her words to him. A balcony to a window, even under such conditions, would be so small as to be dangerous, and Juliet, if she moved, would run the risk of toppling over. On the other hand, if it were near the ground, Romeo could easily lift himself up. Sir H. Irving's way was to have a sort of terrace or loggia, on which Juliet could promenade about.

It will, perhaps, be a surprise to find that there is no balcony at all! Juliet 'at a window' is the direction in the play. It is 
clear that the whole dramatic illustration is in Juliet's voice, face, and gestures, which are to be as it were framed in the window. A sort of rail, indeed, was in front of the window; but it was not for standing on, but for leaning on, thus affording graceful and varied attitudes. Now she is projecting herself well forward, now drawing back, now seen, now unseen-a different thing from the heroine who is promenading it so perilously, often likely to topple over, in her narrow area of a practicable balcony. Here her figure is usually shown, quite out of proportion to her surroundings, which are too small and contracted, for a large, roomy balcony requires a large and roomy house-front, which cannot be supplied. The Shakespearean revivalist having this window, not a balcony, may give himself up to thought and imagination, calling up the reality before him. He may have even seen people at windows conversing with those below. And then he will think of the stillness of the night, the household asleep, the lover prowling in the garden. How would all that be in real life? There would be a general hush, an air of secrecy and caution, talking in low whispers, rising now and again from forgetfulness into louder accents, starting at imaginary sounds, notes of fright and agitation. Instead of all this we have loud declamation, preaching, chanting, roaring sometimes quite sufficient to rouse not only the house, but the neighbours. But by the former method what a grace and witchery and tender fluttering is introduced! To read-such is the impression; but to see it and hear in modern fashion, all the delicacies seemed brushed away. Before us are robust, noisy, vigorous persons, well able to take care of themselves.

And here it may be said that, of all the great and popular Shakespearean characters, the most difficult to represent suitably are these two. For both the performers there will always be this difficulty, for if the players are of suitable youthfulness, there must be lack of training and experience; if the latter are present in force, youth and the charm of freshness have fled. It is a regular impasse. The parts are so attractive and profitable that the experienced players cannot forgo the temptation and have to wait. There are so many beautiful and lengthy speeches to orate with the telling Balcony Scene, and plenty of ' business' all through the play, that the experienced players 
cannot really forgo it. Accordingly, we have the stalwart man, with a good fruity voice and sturdy limbs, and the youngish lady, who will be full or even stout by and by. Mr. Forbes Robertson, Irving-but that was only a caprice-Conway, and many more, were all physically unsuitable, while even Miss Mary Anderson, charming as she was, was a little too mature. To hear these girlish and boyish prattlings spouted forth in a strong, sonorous gamut somewhat jars. It is certainly inconsistent. I would have an intelligent youth and an intelligent girl in her teens, and run all the risks.*

The odd incident in King Lear, where the blind Gloucester is deluded by Edgar into thinking that he has thrown himself down from a lofty cliff, has never been impressively done, owing to the conditions. 'He leaps and falls along' is the direction. But no actor can do this without clumsiness or the danger of breaking his bones. And then there is the floor-a fall on the boards of a room! It might seem impossible to impart any real vraisemblance to the thing. But let us see. How would a person bent on suicide be got to behave in such a situation? By calling on the imagination-for the description of the height is of the most vivid and powerful kind. We seem to be looking down dizzily. Gloucester should show that he was impressed, turning away in horror, retreating and advancing to the imaginary edge. Then, at last, he will nerve himself, turn up his sightless eyes, clasp his hands, cover his face, and stepping on a sort of boulder, jump as it were into space. But in the performance there is never anything of this. All is done literally and practically, while the audience wonders and almost thinks that here the bard intended to amuse himself at their expense. No person arriving at the end of his jump could

* It is astonishing that among the crowded ranks of the profession there should not be discovered for Juliet some young creature, stored with a natural grace and sympathy, having a sweet voice and charm of manner, and devoid of affectation. Great and rare gifts these, no doubt, but that they exist there can be no question. The reason they cannot be utilized is owing to the stifling character of the system which forces the candidate into the travelling company, where some trifling character had to be played perhaps for a whole year, and thus every lofty aspiration is crushed. Who will forget the delightful account of Fanny Kemble's first night upon the stage, and in this very character, where her natural grace carried all before it? More difficult would it be to find a youth similarly endowed, but it would not be impossible. It must be recollected that in almost every instance the untrained actor on his first appearance in town has won his reputation. 
believe that he had fallen from an immense height. He must be led to some raised bit of ground, then tumble down. The other steals away, and, after a far-off shout, returns. He should describe to his friend, with an intense feeling of reality, the immense distance he has fallen. This will impress the imagination.

There is a passage in the Winter's Tale which suggests the great difficulty there is in dealing with some of Shakespeare's stage directions. Antigonus is abandoning the child on the seashore, and, as he lays it down, he hears the sound of the chase, and then 'Exit, pursued by a bear.' What are we to do with this? The bard hardly meant that an imitation bear should be seen. The words equally convey that Antigonus was flying as if pursued, and here, as I have said so often, if the actor be imaginative he can convey by his own dramatic feeling and action the actual terror and sense of the bear's presence. In this he will be aided by the bard's own varied language: 'This is the chase,' 'A savage clamour,' 'I am gone for ever.' The bear eventually tore him to pieces. So there should be a display of the most abject terror, eagerness to escape, but no growlings of the animal.

How absurd and unnatural is the sound of breaking open a door on the stage, or, indeed, of crash of any kind behind the scenes! The traditional way-and it is clung to pertinaciously -is to spring a gigantic rattle in some fashion, and drop a weight on the floor, or break a lath in twain! In real life, under the same circumstances, the sound would not be of this kind or nearly so loud. Indeed, as a general rule, if all sounds were more moderated and kept at a far lower pitch, the sense of illusion would be vastly increased.

The Shakespearean battle, with its 'alarums and excursions,' is familiar to us-nay, is expected as a right. In the revivals they are usually fought in genuine fashion; but how unreal are they! The pattern always seems to be a modern conflict. In one of the revivals I recall how the army actually marched by, drawn up in a column four deep, and stepping in time' right, left,' etc.* When the battle rages, the combatants strike

* In one late revival a soldier was seen to salute his superior officer in the prompt fashion adopted in our day! This was evidently thought to be realistic to a degree. 
with their long swords, so as to produce hollow reverberating sounds on the armour. The super-soldiers bring about a sort of romping scrimmage, like that at a football match-tumble down and get up, or run away. A little reflection will show that it was not in this fashion that conflicts were conducted. We can get an idea from the Highlander battles, described by Scott, in the 'forty-five and other periods, especially from Balfour's stirring battle in 'Old Mortality.' 'There the Scots came on in a long line, with their target, shield, and claymore. It soon became a series of single combats. Where there was armour it was of no use striking it with a sword-the thrust only was efficacious when a joint was sought and found.

But, in truth, Shakespeare's stage directions, 'alarums and excursions,' show what he intended-a rush forward of a few from the ranks, to be met from the other side, to be driven back and pursued, vanishing out of sight. Change then to another part of the field.

Perhaps there should be no fighting, or as little as possible, shown on the stage. Stage-fighting is not drama or dramatic action-that is, the mere cut and thrust, stabbing, etc. The result of the struggle-victory or defeat-is sufficient for stage purposes.

Nothing can be more stirring or animated than the last scenes of combat at the close of Macbeth and Richard III. Every moment the scene is changing to some different of the battlefield. It is now at Birnam Wood, now at Dunsinane, now at Birnam Wood again. These mutations supply an extraordinary excitement and variety. But under the modern conditions of one continuous built-up scene this animation and shifting becomes impossible. With a series of painted cloths it could be managed. There should be great rapidity of change-a sudden darkening, and then the new scene revealed. The spectator should be, as it were, whirled from one place to the other, without time to think. These short intermittent scenes so frequent in Shakespeare had, and must have had, a meaning and purpose, and were really an aid to the play. We were given a glimpse merely of what was going on. A few words spoken, and we were transported elsewhere.

But, then, there should be the most careful and elaborate 
stage management, and not a moment's pause. The idea was that the battle was going on in all directions. Small parties were perpetually coming in contact, fighting, some being driven back, or scattered. Far off in the background there should be permanently a confused crowd shifting and passing on and off. The usual terrific combat between Macbeth and Macduff-always 'fought to a finish,' and ending in the killing of Macbeth coram publico-is entirely apocryphal. No such thing occurs in the play. The meeting of the pair is usually contrived in a very arbitrary and unlikely fashion, both coming in unattended, as if by appointment. One could fancy both being seen at the head of a small party of combatants, hurrying across, and then catching sight of one another. While they fight, the battle should rage in the background; the combatants then suspending their struggle, and drawing near to watch for the issue, just as in the combat between Balfour and his Cromwellian opponent. Then comes an interruption, and the pair draw off, still fighting; a larger force of Macduff's rushes on the scene, when the combatants are borne away in the confusion. We see no more of Macbeth, whose head is brought in later. How infinitely more natural and dramatic all this is than the conventional treatment! But, no, the single combat cannot be sacrificed.*

How desperately used it to be fought!-Richard, panting and growling, gradually spent, after his last Herculean strokes. Even our most conscientious tragedians cannot bring themselves to resign it. And yet-again to repeat it-it is not set down in the text at all! Few, I suspect, are aware of this. Richard's death is 'off,' and is merely announced. Now, there was every temptation for the author to supply the spectacle: it would have been exciting, and perhaps appropriate; but he saw no need for it-a very striking lesson of reserve.

* Sir Walter Scott possessed the power of visualizing combats in a wonderful measure. In 'Quentin Durward' he describes a combat between two mailed warriors. " Nay, if thou wilt have it, take it with a vengeance." So saying, he dealt the Scot such a blow on his head,' etc. 'It descended like a thunderbolt. Durward was dizzy, stunned and beaten down on one knee, but, collecting himself, sprang up and attacked his enemy with the energy of one determined to conquer or die. He then assailed him on all sides with a suddenness of motion and rapidity of attack, now menacing him with the edge, now with the point, of his sword, and ever keeping his eye on the motions of his opponent, so that he was ready to spring forward or aside from under the blows of his tremendous weapon.' 
The conclusion, therefore, is this-that in all the military plays, as they may be called, the author suggested the idea of a general battle, almost cinematographical, by these rapid changes, each scene lasting but a few moments-now a sort of 'running fight,' sweeping across and vanishing; now a combat between half a dozen, in short, endless 'alarums and excursions.' Even in modern conflicts, as described by witnesses, we get little more than this-bands of men hurriedly flitting about or lying sheltered, retiring or advancing. And who shall deny that the bard's method was more scientific and dramatic than the modern system of sending on a regiment of supers?

Luckily, horses and other animals can never be so sufficiently trained as to act or take an intelligent part in the scene. On the contrary, horses can rarely be brought to tolerate the new conditions under which they find themselves, such as walking on a wooden floor, ascending sloping platforms, and, most trying of all, the glare and flare of the lights, the noise of stage firearms, and the crowds of unfamiliar and gaudily dressed beings that press upon them. What wonder that they become uncertain, scared, and ready to shy? And let us observe the ridiculous precautions that have to be taken to ensure safety. The noble lady entering in state on her palfrey, with her train of courtiers, must have always three or four retainers carefully holding on to the disturbed animal-two at his bit and bridle, others at his quarters. We can hardly imagine a dame of high degree entering her castle in this fashion. The process seems to nullify the impressive state and solemnity that was intended. And what effect can a horse dramatically produce except as a mere exhibition of a horse on the stage? Not so long since an excellent and sterling actor had to mount one of these beasts, who took fright and actually threw him coram populo !*

* There are other accidents, too, less painful but more grotesque. It is always something degrading to note a row of hired horses outside in the street, waiting by the stage door for their turn, with a sloping platform resting against the wall, by. which they are to mount. There is no gain, either theatrical or other, in introducing such animals on the boards.

In Mr. Tree's production of the Winter's Tale there were some pretty pastoral scenes-rather superfluous, no doubt. To spread a sort of agricultural tone over the piece, a shepherd was exhibited leading on a donkey. Shakespeare and a donkey! surely the first time this combination ever was attempted. True, in the pretty opera Veronique we had Miss Ruth Vincent on a donkey; but this was in France, where ladies are often seen on such 
The constant invasion of the stage by children seems to afford an intense and also a ridiculous satisfaction to audiences, but it is an abuse and corruption of all dramatic art. These poor little things can give no intellectual entertainment, as at their age they can have no talent, no training, and not even the necessary physical gift of utterance. Their voices being weak and immature, and unable to carry the words across the footlights, they are taught a sort of scream or croak, which is painful to listen to. They usually show an unpleasant forwardness and vanity, for they figure as prodigies. Shakespeare exhibits scarcely any children, save, perhaps, the young Princes in the Tower, Mamillius, etc., and these he treats with the utmost propriety. This treatment should be to show them as children, speaking naturally in their own proper gamut, just as children of their age would speak, without straining the voice and with just elocution. But, it will be asked, how are these naturally weak tones to travel to the audience? By the aid of training and elocutionary schooling. For this end the Princes are usually played by intelligent girls some fifteen or sixteen years old, for girls of this kind look more like youths than boys themselves. How natural is Brutus's page in the Tent Scene, who has simply to display his fidelity to his master. The Princes in the Tower should use low, gentle tones, with a certain artlessness, always found in children. What pranks have been played in the scene where the young Princes talk with their redoubtable uncle, the young Duke of York, the comic one of the pair being schooled to answer pertly and extort laughter by his prattle! The audience must perforce say to itself, as it smiles, 'Oh what a clever, quaint, and intelligent child is this! How odd and funny, too!' whereas the impression left should be one of deep pathos.

Dying on the stage is regulated by conventional rules and

animals. What was gained by it? or of what use was it? or what precedent was there?-for shepherds do not invariably keep donkeys or lead them about and then let them go. For this animal was allowed to stray about, when he wandered to the wing, where he began scratching his ear comfortably, to the enjoyment and tittering of a foolish audience. Having served his purpose, whatever that was, he was then led out. A donkey had, in fact, been shown to the audience-that was all! Surely here was a grave solecism, something unbecoming, too-the reductio ad absurdum of the profane vagaries of revivals. 
traditions, and is probably as unlike actual dying as anything that can be conceived. In real life it is a far longer business; the approaches of the 'fell sergeant' are slow and gradual, take a long time even in the case of poisoning or running through the body, so that the exhibition of the abrupt agonies to which our actors are so partial are matters superfluous. Persons stabbed with a dagger, or beaten to the ground, do not die in a few minutes. Moreover, these people contrive to talk up to their very last breath. Even Shakespeare's dying heroes are thus loquacious until an abrupt halt is always cried: 'Dies,' which is equivalent to 'Exit '-that is, he or she disappears from the scene. When a man is run through the body after a combat he may be virtually considered killed on the spot. Such agonies displayed elaborately are out of place and repellent.

In all the representations of Desdemona's death or murder the stage managers have clung to one arrangement-a large and spacious bedroom, stretching back a good way, with an average-sized four-poster at one side, but still a good way off. This was Booth's disposition. Irving, I think, placed it against the central wall, and also rather far away. This, no doubt, gave the Moor opportunity for display - ' gave him the stage,' in short. The unhappy lady seemed like a puppet in her bed. But, turning to Rowe's early edition of the play (I 709 ), when the old traditions were still fresh, we find a more effective disposition. We should consider that here are two performers in a very prominent and highly dramatic situation, who are both ' on the boards.' They ought to be well forward, in view, and it makes no difference that one is standing and moving, the other prone and motionless. The bed has become a new level-a stage for the heroine. Accordingly, in Rowe's the bed is of an almost monumental description, with catafalque draperies, high posts, and is brought forward to the front. It almost fills the breadth of the stage. How different the effect from that of the poor skimpy cot usually exhibited with such a lack of dignity, and which invariably suggests some modern bed, with pillows, sheets, etc.! The counterpanes were then richly coloured and heavily embroidered. Thus was Desdemona made prominent and dignified; her action in full view; her voice and speeches, instead of faint, far-off, 'bleatings,' being full and important. She could sit up and plead her cause on equal terms with her assailant. 
Mr. Forbes-Robertson, a most intelligent and cultivated performer, when he revived Hamlet, introduced a new and rather bizarre method for Hamlet's death. It seemed to him that the great Prince ought to die comfortably-if not 'in his bed,' at least in his chair. So that a roomy arm-chair was brought forward in the middle of the stage, in which he was placed, and there, having uttered the mystic 'The rest is silence,' he remained peacefully, with a gentle smile on his face, his hands resting on the arms of the chair, and so tranquilly passed away. The attendants stood grouped round, watching and in perfect stillness. Now this was well intentioned and conscientious, but there was a most unheroic air about the business-a kind of homely domesticity. But in those same barbaric times it was 'the thing' to die where you fell-that is, on the ground. The rough-and-ready warriors would not dream of lifting their comrade to a chair or sofa: he was better where he lay. The other was a mere refinement, and dramatically was less telling. The picture, however, remains in the memory as something naive and even grotesque.

There was an old stage device, once in high favour, when the player who was stabbed or shot had to fall flat to the ground, tout bonnement, without bending his limbs. No one, of course, ever fell in this fashion, but in a heap, as it were, dropping down slowly. 'Falls on his sword' is a stage direction in some of the Shakespearean plays-a thing difficult to convey even the idea of. All these operations, if carefully revised and some principles were thought out, would have a far more dignified air. One principle would certainly survive-that the operation should be quite indistinct, that neither the dying nor the death should be emphasized. But it will now be said, What would you have? You simulate the agonies of life: then why not the agonies of death ? You show the dissolution of mind: why not that of the body? The answer is simple: The agency of mind is movement and drama; that of the body is merely a pathological exhibition. It does not tend to movement, but to stillness, and is stationary; neither are they the emotions and sufferings of soul or of the mind, but of the body, oppressing and overpowering the mind.

In those pieces which turn upon likeness of persons, such as the Comedy of Errors, it always seems obvious to the manager, 
or to the unintelligent crowd, that if it were his happy chance to find a pair of twins who were also actors, the fortune of the piece was secured. He would think, if the likeness were so strong that it became impossible to distinguish between the persons, there would be the ideal performance. This actually came about many years ago, when the brothers Webb played the two Dromios. There was ignorance here of the true principle, and the result was shown in the performance. For no one could distinguish one from the other, and practically it seemed as though the parts were performed by one person. This would destroy the whole entertainment. The true method is to have the parts performed by persons who are somewhat like in height, shape, etc., but distinguishable from each other. The truth is, persons who know twin relations familiarly can distinguish them readily, but to persons not so familiar, such as the audience, persons who are only thus partly alike will appear very like.. There should, therefore, be a likeness, but not such likeness as will cause confusion. Irving, when he came to do the double part of Lesurques and Dubosc, saw this danger, and made the likeness slight enough, only to be recognized by careful searching glances, and this was further disturbed by the contrast of dress.

The late Augustine Daly on his visits used to bring with him 'practicable' doors, their cases, panels, locks, etc., all solidly made like real doors, with mouldings, etc. Yet the effect of this solidity was in odd contrast to the flimsy nature of the painted canvas walls beside it, which shook and quivered as they shut. But with the most perfectly simulated door, fitted with its solid case, bolts, locks, etc., there is always a special rattle or clatter, quite different from that furnished by the real door, and this betrays the imitation. The reason is that the real door is fixed in a solid wall, and it gives little or no sound. At the Français and the superior theatres I have seen doors that closed with a soft gliding motion, floating back, as it were, automatically, and closing so that the joinings were scarcely appreciable. The effect had a sort of dignity, as though the situation was too lofty to be disturbed by the vulgar and earthy incidents of loud-sounding catches, boltings, etc. How often, too, when the villain gets the heroine at last 'into his power,' have we heard him lock the door ostentatiously, it 
being carefully fitted with a key and lock! We actually hear the bolt being 'shot home.' The whole tone of the dramatic world is so quite above these earthy elements. It used to be enough that the characters came on and went off, 'enter' and 'exit.' Fifty or sixty years ago there were no doors at all, only the 'flies.' The characters left the stage, no one cared how ; it was enough that they were gone.

The putting a ship on the stage-with its deck, masts, sails, etc.-though it superficially appears to furnish illusion, really destroys it. Mr. Tree produced a wonderful piece of construction of this kind at the opening of The Tempest. It was almost startling, from the stormy skies, the terrific hurricane, the vessel labouring in agitated waves. Nothing better has ever been seen on the stage. We saw the deck now showing its whole length, with the distraught passengers, now tossing, and finally sinking under the waters. What more could we ask in the way of illustration? Yet it was all on a false principle, and simply frustrated the author's meaning. It was forgotten that a regular scene is going forward. The boatswain is keeping the passengers in order, requiring them to go below; there is the sense of things getting worse and worse. 'We split, we split!' Here we make our first acquaintance with the characters, hear them talk, and see what they are. An important part of the play is, in fact, going on. There is talk, agitation, alarm. But what was the result? So great was the din of the storm and the general 'row' that literally not one word was heard-possibly not a word was really attempted to be said. Instead, we were given a very fine and startling panorama of a shipwreck.

But there is a further objection. There is and can be only one stage: that is the section of ground, or Mother Earth, on which the characters stand. Here we have two, for the deck is a second one. That the bard intended that his deck should be the stage, or vantage-ground for action, is clear. So with all those galleys, etc., which figure in Antony and Cleopatra, and which are all out of proportion, and offer only a delusive accommodation.*

* Much interest is always excited by the opening scene in the Rheingold, where the maidens are seen swimming and floating about. This is received as perfectly illusive ; but no one could obtain so vertical a view of a river, though we may look down upon it-save, indeed, in an aquarium tank, which the arrangement always suggests. 
There is now a sort of tapping instrument in use-a French patent, I believe-which is supposed to represent the galloping or trotting of an approaching horse. It can be worked fast or slow, but does not convey any idea of the kind. All sounds or noises behind scenes-shots, knocking, music, bells, organplaying, horses trotting-are always brought too near. The audience is always convinced that they are caused by the prompter at his side, as certainly as though we saw him handling the knocker. In Faust, when the congregation were coming out of the church the organ swelled and boomed, and made all quiver. No one, however, in real life hears the organ from the outside, save as a faintly buzzing and enclosed sound. Bells, too, which are far away, high up in the church tower or steeple, do not din us and clang as we hear them on the stage.

Thunders, storms, lightning, rain, with other disturbances of the elements, offer a difficult matter for treatment, so as to seem probable. The rolling cannon-balls over our heads is certainly as alarming as a real storm. Lightning, too, is nearly perfect. But, still, a glance at the draperies above or the boards below, telling us that the storm is going on in an enclosed room, prevents all deception.

This brings us to the outcast Lear, and to his sufferings from the pitiless elements :

'Blow, wind, and crack your cheeks.'

The bard himself seems to plan this storm with wonderful intensity and significance. Difficult as it is to arrange, I have no doubt it could be made to rage with infinitely more effect than has been hitherto attempted. The thing would seem to be to convey the effect of a terrible storm on those who were caught in it rather than the storm itself. There is art in spreading it over the two scenes- 'The Heath' and 'On the other part of the Heath'-which gives an idea of vastness and spreading power, the covering of a large tract of ground.

At the end of Act II. it all begins :

'Alack, the night comes on, and the bleak winds Do sorely ruffle.'

And news arrives that the old man had gone from shelter. Here there should be a growing, lowering darkness, and far in 
the distance be heard the mutterings of the coming tempest. The performers should look forth with alarm and shivering, and hurry away, as if for shelter. It is clearly to be a most unusual and menacing storm. Between the acts it goes on, still growling and rumbling, but far away, gradually drawing nearer, until as the curtain rises we see the lonely heath spreading away, without a tree for shelter.

It would require a painter of genius and poetry to convey a sufficient idea of such a heath. Presently it begins to rage. The thunder should be studied, not always in rolling peals, but often in short, sharp claps, succeeded by sudden darkness and deluges of rain. Enter then a gentleman and Kent, who should come in with bent heads, struggling with the rain and gale, and speaking with difficulty, like people who are caught in real storms, so buffeted that they cannot keep their feet. Indeed, everything should be uttered hurriedly and with interruptions. They go out into the darkness to search for the King, speaking loudly to each other. He that ' first lights on him ' is to holla the other.

All the descriptions of the storm given by Lear and Kent are wonderful for their vividness. He calls it 'this dreadful puddle o'er our heads.' It is obvious, therefore, that his long speeches must not be delivered as histrionic orations, but as spasmodic utterances, contending with the hideous noises about him. Sometimes at a fresh outburst he will have to stop and cover his face with his hands. But I need not dwell further on all this. When Lear goes out to seek for the hovel he might seem to be driven back by the force of the gale, and then is dragged onwards as by the fool, both with bent heads.

Are we such slaves to convention as to assume that the tremulo music, fortissimo, with chromatic scales and much double-bass, is actually essential, and so expressive as to convey the notion of a storm on land or at sea? Also is there always to be this terrific noise-beating of kettledrums, only too well knowen to be drums? In such a storm there are no noises of that kind, though the wind howls and whistles, and at times there is a sort of roar. If we are imitating these phenomena, we should try with something better than kettledrums. By the way, Mr. Tree has another atmospherical device-an imitation 
of heavy showers, but which really suggests water trickling from a cistern.

There is a strange passage in Julius Casar which occurs on the eve of his assassination, and where a sort of double scene occurs. He is shown, attended by all the conspirators, proceeding through the street to the Capitol. Cassius presses him to pardon some one, and Cæsar answers, "What, in the street? Come to the Capitol.' After a few more sentences we find them apparently in the Capitol, where the event follows, and Cæsar sinks down at the foot of the statue. Street and Capitol must therefore be in one scene. This would require the Capitol being put far back, and the exciting issue would take place afar off, which would not do. But on the old platform principle, without scenes, such events, with succession of figures, would be quite independent of successive scenes. The audience would know by the speeches that the first portion was in the street. Cæsar would then take his seat, and they would know that here was the Capitol. This was clearly in Shakespeare's mind. In real life we only thus think of the succession of incidents; the locus in quo does not dwell in our memory. At the same time it must be admitted that under the modern arrangement the managers are quick to mark out the division of scenes, as it suits their purpose, or, as we have seen, the author has merely followed the order of events. But how are we to deal with these two scenes thus confused into one? Managers cut the knot by fashioning them into two scenes, but in that case the first is too unimportant and too short to support the weight of a scene. I would place the Capitol at the side P.S. The street should be O.P., and the agitated dialogue take place there. But the boundless resources of the scenic artist might be relied on to produce a satisfactory effect.

There is yet another perplexing matter for treatment-viz., Shakespearean eating and drinking. This is always done in a thorough comic fashion, as though the performers had very hearty appetites, and fancied that eating and drinking was a humorous, interesting thing, and a part of acting. Now, eating or drinking is but purely mechanical, and utterly uninteresting. There is nothing dramatic about it, save in the case-such as that of Falstaff-where the character is that of a greedy fellow or 'guzzler.' It should therefore be as perfunctory as it can 
be made. In real life, say at dinner, people eat and drink all but instinctively; nor do they do it in any ostentatious manner.*

Shakespeare, indeed, liked the state and solemnity of the banquet. His grand effort in this line was the Macbeth feast. And how dramatic it was! It was the banquet in its quiddity. No thought of munching or quaffing there. We have seen representations where every guest had his plate, knife and fork, etc. Nothing was finer than Irving's arrangement, where a number of rude, short tables of antique form were spread diagonally over the stage in the great Norman hall. It was in scenes of this description that Irving's true poetical feeling was shown. His great Norman halls were really noble conceptions. I fancy his least successful play, King Lear, was the finest of all in this respect. His heaths, banqueting-hall 'interiors,' etc., were lonely, grand, and suitable. There was, however, a certain monotony, owing to the constant repetition of these Norman chambers.

In The Merchant of Venice the choosing the caskets by the three candidates is usually fused into a single scene, when they come up and try their chances one after the other. There always seems a vulgarity in this, for it suggests a sort of competitive examination, the lady of the house looking on, while the suitors draw for her. In practical life the trio would not arrive together. Two at least are highly important personages-the Princes of Morocco and Arragon. Each would require a special function and special audience in all state. It should be a highly momentous and mystic ceremonial, to be directed by something more than mere chance. Portia comes in with her train to meet the Prince, who has his retinue. There should be stately greetings, and bowings, and music-a regular triumphal entry. Nor would I have the caskets on a sort of altar, but rather carelessly disposed upon a table behind the curtain. This seems to have been the bard's notion.

* It is not dramatic. In that amusing drollery The Man from Blankley's the guests are shown at a large round dinner-table, and the dinner itself is acted all through, which is thought all-important. There are a parlourmaid and a butler constantly going round and round, filling glasses, changing plates, etc., all which is vulgar, uninteresting and mechanical. Instead of emphasizing I would minimize these things, soften them away, as it were, into indistinctness. No one would miss them, for there is no end to this realizing. 
Let us conceive of it solemnly and earnestly treated. As a serious portion of the play it would have an impressive air for this reason, for it would show how complete was the preference given to Bassanio, these personages of State being rejected for him. In short, it is always treated in a sort of trivial manner, even as a good-humoured jest, conceived by the gifted lady of the mansion.

When we turn to the text we find that it is intended to be a really momentous and important transaction. It is spread over three scenes, and each candidate has a scene to himself. And no wonder: for here are solemn proposals of marriage; here are people who have travelled from a vast distance to make their proposals, on which so much depends. It should be a dignified thing. Instead, all is usually huddled up into a single scene; it is treated as a sort of practical joke-these duskycoloured fellows are fair game for the lively Portia.

There is the regulation fashion of dealing with priests, Bishops, Friars, Cardinals even, on the stage, which always seems to frustrate the end intended-that of impressing us religiously. Highly unclerical-looking figures are shown dressed in their robes, with faces often ludicrously inconsistent with piety or the clerical calling, owing to the attempt to compose the features to a sort of holy expression. No doubt they do their best, but they and their stage managers can only guess at how the thing should be done, and follow old stale stage traditions. And how comic are these attempts, as when marshalled in a procession these clerics stride forward in a slow and solemn stalk, much as Crummles did at Mr. Lillyvick's wedding! The truth is that Catholic priests and Bishops do not stalk about in this fashion; they walk like other people, even in a procession. No one thinks that he is bound to show by his gait and bearing that he is ecclesiastical. They wear their ceremonial dresses as if well accustomed to them. The result of this artificial bearing is undramatic. The spectator looks on them as puppets. So with their speech, which it is designed should be in pulpit tones. The supers, who are usually entrusted with these parts, convey something mean and undignified. In vain they posture and look sanctified: they seem just what they really are-supers dressed in clerical clothes. Even the lamented Irving, who made prodigious 
efforts to be accurate, employing 'Burns and Oates' to secure him robes, etc., was scarcely successful in his aims.*

Steps, and flights of steps, are much insisted upon in scenic arrangements. The protagonist thinks it a mighty point that he should make his entry down a flight of steps; the slow progress, he knows well, draws the assemblage for a longer period than would an ordinary entry. These steps, somehow, always seem to reveal their nature and origin-they are a piece of framed carpenter's work-and we can see, in our mind's eye, the assistants carrying them on and laying them down in their place. We can see, too, most clearly where they join the canvas behind, and how they lie on the floor instead of being built on it. A King coming forth from his palace must descend his steps. Such accidents as these have nothing to do with a dramatic feeling. A King upon the stage entering in any other way has no loss of dignity.

In the opera of The Huguenots from time immemorial there has always been a gigantic flight of steps that mounts to the top of the scene nearly, but without which, as it is thought, the effect of the whole would be lost. This is for the special entry of the heroine, who is seen descending it slowly, step by step, to arrive at last in the presence of the court below. It is a painful and well-practised descent, not without danger. Beautiful music is played as she descends. We have grown accustomed to it, and should miss it if it were abolished, but I never could see the meaning of it ; the lady might just as well have come down a ladder.

We recall the agitated scene in Othello, where there is general riot, confusion, and killing. Iago had artfully sent out Roderigo to raise the alarm, and the bell or tocsin begins to clang violently, so that the General himself was roused, as was intended, and hurries down. Now, this midnight confusion is never made sufficiently alarming. We could imagine all sorts of troubled elements, as was natural in these wild Italian cities

* How, too, is it that in all other crafts the workmen seem clean, sturdy, well-clad fellows, such as a carpenter, with his rule in his pocket, his clean linen apron, etc.? But the stage carpenter-so called even at the superior theatres-what repulsive, dirty, gin-drinking fellows in appearance they are'ill-drest, ill-kept,' and like Johnson's leg of mutton! One must not be unjust, but I fancy they are always cadging on the players, the richer ones paying lavishly, the poorer having cash extorted from them. It seems written on them that they must go consiantly out to refresh. 
- people roused from their slumbers to see what was the matter. The bell generally clangs on in a methodical way like a church bell. But it should be a violently agitated bell, striking fast and furiously like a fire-bell, and rising above a general din of confused murmurings and voices. Hence it is that Othello cannot hear himself speak, and calls out: 'Silence that dreadful bell!' Indeed, all the public scenes in the play should have this hurry and agitation, the words spoken fast, every one excited, so as to contrast with the more deliberate and intense horrors of the interior action. At home here of a still night what is more significant than the fire-bell, with hasty unceasing strokes, calling importunately for aid, and rising above the distant and indistinct hum of voices? In Mr. Asche's excellent and very satisfactory revival these things were not thought of : the bell only rang now and again, then stopping altogether, or ringing in a very gentle way, so as not to interrupt the speeches. Thus it seemed strange to hear Othello say in a casual, quiet way : 'Silence that dreadful bell!' which was not dreadful at all. In this Drunken Scene, as it is called, all poor Cassio's tipsy utterances were punctuated by roars of laughter from the crowd as if in a common café.

On Mr. Asche's revival of As You Like It the critics grew wanton in praise of the scenes, which were really beautiful pieces of work by Harker, who rang the changes on every form of forest life. Here we saw thick groves-vast gnarled monarchs of the forest, young and old, in profusion. One could not but admire the artist, but nothing more discordant or disturbing or unscenic could be imagined. The scenes and the characters and action all diverged. These glaring, flaming trunks of trees, tumbling at length in all angles, completely overpowered the human figures, behind which they rose and sprawled. They seemed monsters, and to be themselves acting in competition. It was impossible to devise a better instance of scenery overpowering the human element and action. The figures all became insignificant by comparison.

But why should objection be made, as every one was satisfied and enchanted? What would you have, it will be asked, if not a living forest of this kind, with all its great trees individualized ? I would have the resemblance to a forest. The trees, leaves, and branches, should be indistinct and blended together in a mass ; 
a sort of misty colourless veil over all, the colour subdued to very low tints; nothing staring or assertive, but all richly mellow and indistinct; just as $\mathrm{Boz}$ always took care to have violetcoloured screens placed behind him at the readings to 'throw him out.' But here, apart from the clamorous colours, the whole forest was ablaze with fierce light.

How barbarous and pristine are the invariable methods of changing the scenes! A shrill whistle is heard; then follow a clatter and flappings, as of a ship in a storm ; great screens are seen tottering and twisting; the hands, arms, often figures, of the men doing this being sometimes visible; other screens are brought forward, and the thing is complete. This is rude to a degree, and destroys all sense of illusion. Sir H. Irving, I believe, was the first to introduce the practice of suddenly and completely darkening the stage, though the noise and flappings still continued. The darkening was a good idea, but it was too sudden and abrupt. A better effect would be to lower the lights very gradually and raise them again with equal deliberation. Complete darkness is unnatural, and prompts one to ask why the stage at the close of a dramatic situation should be reduced to this condition? Goethe has noticed this defect, and points out that in real life there is never a complete black darkness where there is a large space; you can always see objects.

Another device which is thought to impart mystery to the arrival of ghostly visitants is the issue of clouds of steam from apertures in the boards! This goes on from small beginnings until the whole stage is enveloped in vast fumes. It is palpable steam, and can be taken for nothing else; for it is attended by a loud sustained hissing sound, denoting the escape from the boilers below. The thing is almost ludicrous, and instead of being poetical and illusive, quite prosaic.*

Often we meet large carts laden with screens-so-called scenes and other paraphernalia-we note some strange rickety things piled up : large papier-mâché vases and goblets, lookingglasses for the Duchess's drawing-room, an affair of tinfoil-pots of artificial flowers-the front of a hut with a door that opens, and are inclined to ask ourselves, How is this trumpery to be

* I have spoken before of the conductor of the orchestra. He is really the chief obstacle to illusion, for with his band he is assumed to take share in the performance of the stage. And yet he is really a man in the audience, waving his stick and gesticulating in a commonplace way. 
associated with the grand spirit of the drama, or how on earth can it help it? Imagination and thought are much cheaper things, and far less troublesome.

In the pantomime at one of the great theatres there was much flourishing about certain giants I4 feet high, held forth by managers and press, all as prodigies of scenic art. We were told how they were fashioned, shown pictures of them during the process, while the public and its children were all lost in wonder. Yet how elementary the thing was! Some men mounted on tall stilts and carrying the heads on poles! It was impossible to see them a moment without recognizing these homely agencies. And yet with it all there was a far more illusive method which might have been applied more by an appeal to the imagination-to convey the idea of a giant, and represent the others as feeling the presence of such a being.

I recall an excellent performance of Gulliver's Travels in which this principle was applied. Gulliver was personated by a tall man, the Lilliputians by very small children. That was all the realism. But Gulliver acted as though he were a giant among pigmies. One little touch was excellent.' The small army kept firing at his legs from their tiny rifles, and he, while making them a speech, would rub his legs unconsciously, as though something were irritating them. At last, discovering the cause, he said impatiently, 'Do stop that!' as though some gnat or other insect were irritating the parts. This really was perfect illusion, much more certainly than palpable stilts and masks carried on poles.

Yet another instance. I have an Empire clock representing Phaethon driving the chariot with two flying horses. The whole is beautifully modelled and full of spirit. The wheel is the dial. On looking at it closely, you see that the horses are about the size of large dogs, coming up to Phaethon's thighs! Yet so genuine is the artist's purpose, and so craftily contrived, that this would escape observation. His object was to bring the whole action into a contracted space, which was commercially necessary. On the fitting scale it would have been too monumental. Here was true illusion.

Huge structures are noisily wheeled away-you hear the castors; others come rolling on to take their place; skeleton 
columns are pushed up-obviously flat profiles; ' rakes' come out of the ground; sheets of canvas are let down, and wave in the air for many minutes. And this change the fairy queen is supposed to have brought about by her magic power. The curious thing is we believe in it all implicitly. We have been trained from our childhood to accept these makeshifts; we have been brought up on them ; we have always been saying to ourselves, 'This is real illusion, because it is on the stage.' As I have said before, there is more genuine illusion in the vast green curtain, with its mournful folds, than in all that goes on behind it.*

That most captivating of fairy tales, Alice in Wonderland, with its sequel-the work of a man of the most delicate fancyhas been placed on the stage, and we could well imagine its being effective, if treated with sympathy and reserve. $t$

It was at last adapted, but in a very practical and businesslike shape, much as a pantomime might be handled. Still, so full of charm and poetry is the story that the effect depends rather on the interpretation than on the adaptation.

Mr. Seymour Hicks has brought it forward several times, shaping it like one of his musical comedies, filling it out with ' knock-about business' and the jovial fun that is familiar at his theatres. The Mad Hatter, one of the quaintest and most grotesque of characters, became a literal mad hatter, indulging in comic antics. Yet it is a real character, such as one would see in a dream-so serious, so much in earnest, and carrying conviction in his curious upside-down remarks. This notion of the whole being a dream, with speeches and acts such as we find in dreams, would, if thoroughly carried out, have the most original and weirdlike effect. The Queen and the rest wonder at Alice's intrusion, pity her ignorance of their fantastic speculations, and are always trying to enlighten her. But no, everything must be taken literally. The dor-

* As a child one believed firmly in the old pantomime tricks, the box that the clown dragged on with some comic label attached. Presto ! a cord was pulled; the various flaps opened with noise, and a little policeman came out and walked. Nothing less magical could be conceived, but it served.

+ I recall Mr. Dodgson, the author, consulting me earnestly as to how he was to have it dramatized, and who would be a suitable person for the task. The difficulties in the way were great, but eventually Mr. Saville Clarke undertook the business with some success. This, I believe, remains the sole version. 
mouse and the other creatures become pantomime animals, and act as such.

I believe that a true and faithful version by some properly gifted writer would have great success. The music, too, might well engage the talent of a great composer: it should be of the most delicate, fairylike cast-a second Midsummer Night's Dream overture. But that is only another dream. That sort of raree-show, the modern pantomime, is always presumed to be based on one of the children's fairy-tales, which are mauled and twisted beyond all recognition. And yet there cannot be a doubt that if one of these always interesting stories were treated with faith and sympathy, and the story followed out strictly and set off with the modern adornments, it would be absorbingly attractive for children and grown-up folk.

Thus, if Cindevella were acted from beginning to end without making everybody and everything farcical, it would become a delightful thing, which the children would dream of for weeks afterwards. But no, the Baron must become a comic Baron, giving his dances and songs; and the two wicked sisters must be performed by the best comic males available. Again it must be said, the reason is that we are so destitute of the feeling of imagination or romance, and can only understand plain hard fact.

It used not to be so. Fifty years ago, when scenes were not dioramic shows, but pictures, these feelings were very much abroad and cultivated. Who will forget that pleasing, absorbing melodrama, Victorine; or, I'll Sleep upon it?-a quarrel and 'break-off' between two lovers. Victorine in her dreams is shown the whole future life of the lover-his decay, his sinking lower and yet lower, until at last, I think, he is on the verge of the scaffold, when she awakes. The old familiar room is back again, and she hears his cheery calling from outside.

The Corsican Brothers is another of these romantic pieces, a melodrama of the very first class.

In the great spectacular theatres, it would seem that little is known of these laws of illusion, or of how to impose on the senses. Thus, to produce the effect of numbers, you must have numbers. At Drury Lane at Christmas one has seen the stage literally crammed with bands of girls, who have scarcely room to turn round in. The effect is almost the contrary of what is 
sought. But in some of the Paris theatres you will see that the material of, with five-and-twenty or thirty bright, intelligent, well-favoured figurantes-a scintillating quicksilver mass, each item creating an interest of its own-the effect of numbers is produced. Then, too abundant space acts in the same direction, though the vulgar idea is that filling space needs numbers.* Movement, too, suggests number.

This law of representing numbers by few should be applied in every department. The whole behaviour of crowds has to be revised. When Squoire makes his speech to the rustics, what strange cries all in miraculous unison! Still, since the Meningen visit there has been a vast improvement.

In the West End houses, when the curtain rises we are certain to see the drawing-room at "The Towers" crowded up with furniture. There are large ottomans, settees, easy and uneasy chairs, little tables, queer sofas, cabinets, etc. These things are de rigueur. Here they may be, but not in real life. The players can scarcely turn round; they have to steer their way cautiously round the ottomans and past the sofa until they reach open country by the footlights. But that will not dothey must be among the furniture. And yet how can there be dramatic action, movements, spontaneous bursts, if you have to think of such impediments? In real life so much furniture requires corresponding room; no one has to move about in this encumbered fashion, as though he were in a furniture shop. The block arises from the false principle that the whole, whether a Duke's palatial chamber or a modest citizen's drawing-room, must be compressed into the same unchangeable space. Yet in the old simple days of pure drama the furniture was symbolized, as it were; there were the two chairs-no more-and a table! But here is a simple element of illusion.

One of the dramatic graces of the old Lyceum under Irving was the vast green curtain-now old-fashioned and exploded everywhere, but yet a most potent element. Who will forget

* In the Second Empire days I witnessed a ballet dance on the subject of wine, in which brilliant beings took for characters the different descriptions of wine-Burgundy, claret, champagne, etc. There were not a score of performers, and yet each and all were vital, brilliant, full of movement. It was a fascinating spectacle, and a strange thing to contrast with one of Sir Augustus Harris's monster shows, where a couple of hundred beings were all huddled together close to the footlights. 
Elia's description of the sense of mystery it created as you entered and saw its vast immensity - hanging solemnly between the two worlds ? It seemed now and again to float and drift like the ocean itself. And then, when the tragedy was done, with what magnetic power the dark folds descended, without noise or clatter, seeming to enwrap, or rather dissolve, the scene for ever! Instead, we have now the gaudy, flippant drop scene, with its too palpable wooden roller, the very essence or suggestion of prose and business life. These things are not by any means fantastical, but practical and of experience.

Nay, we have nowadays a perverse destroyer of illusion in the iron 'safety curtain,' squalid and dirty, smeared with some colour, and marked with a vulgar inscription. It is no curtain, but a metal screen, and should be treated honestly as such, with metal mouldings and ornaments.

Yet there are, however, conditions under which I think the luxury of scenery and decoration is legitimate, and even desirable. The Grand Opera Houses in the capitals-our own shabby one excepted-are splendid things from the sumptuous style in which they are equipped and maintained. We think of gala nights, with the beautiful interior, its painted dome, where gods and goddesses and cupids float in the ethereal blue; the finely designed balconies and boxes-golden cages filled with lovely beings, diamonds and general glitter. We turn our eyes to the vast stage, crowded with gorgeously dressed figures. We expect magnificence so as to correspond with the audience. Everything should be in keeping. The stage is usually so vast and spacious, and the arrangements so artistic, that the vast monumental arch and the rich hangings seem to be the opening to realms of fairyland. This is owing to the charm of music and song.

Once more, how astonishing the fashion in which we cling to the old stale tricks; as in the Greenwood Tree Scene in As You Like It, which it would seem is usually presented as it was presented fifty years since. Some very long and yellow trunks of trees are laid down conveniently to right and left to serve as seats for the nobles. These are mere bits of painted canvas, covering wooden benches. Then the trees, with their spreading branches, stretch across-cut out on the borders. The gnarled trunks are below. Critics will, of course, be loud in praise of 'the 
beautiful woodland scene-so leafy,' etc. But though the ground is of canvas, painted, and real twigs and leaves are strewn about, who for a moment can fancy they were in a forest or anywhere but on a stage. Who that has walked in a forest or a wood but will recall the necessary absence of light, the general gloom, the solemn air of the trees? Here they have always a frivolous look; in the usual gaudy blaze of light they seem as if hung with ribbons and lace. We also see easily to the tops of the trees and their higher branches, which we could not do were we in a real grove.

In Henry $V$. I can recall a sort of baronial hall, cleverly planned and laid out, rising up to the roof, but made of strips of painted canvas! The different archings, placed one behind the other, with thin supporting columns, were all cut out of the same material. The scene-designer's art is shown in combining the two methods-the real and the illusive. But is there any illusion? The canvas pillars every spectator, excepting those at the very back of the gallery, can see are mere strips of painted linen hanging down. It is the same with the groinings in the roof, with painted timbers which flutter backwards and forwards with every draught of air! Such, in truth, are not illusive at all, and do not pretend to be. They are oldestablished conventions, agreed on by audience and managers.

As a further illustration of these scenic incongruities, we have noticed that there are always two lines that will cut each other at right angles-one that of the hard and stiff sidescreens, the other that of the soft and pliable borders. No ingenuity-and the thing has been often attempted-will bind the two together. It is hopeless, because the discrepancy is radical and there are two systems opposed. We often find the bottom of the borders lying on the top of the screen, sometimes drawn up in crumpled folds, the material falling down on each side, while the wooden tops of the scene are clearly visible, just as much as in a large folding screen that is drawn to the fire. Yet this rude arrangement is complacently accepted. The critics will praise the ' fine set in the second act,' while every one who raises his eyes can see the unadjustable mixture of linen and wood.

The contrast between the scenery of fifty years ago and that of the present day is extraordinary. Then a scene by Telbin or Stanfield, as I well remember, was like a landscape of 
Wilson or Constable, and as solidly painted-a tall brown tree at the side, the foreground rich and dark, and full-bodied. Now the same thing would be splashed in-sketched, ratherall yellows and pale greens : a single splash or dab does for a leaf, a single stroke for a branch. But Telbin's scene would not come out under the present conditions of fierce light.

It is astonishing how this refined and mellow treatment harmonized with the dramas. It was the same with the dresses -they and the figures were blended with the background. There was a general air of repose. The scene-painters then were masters, and several became Royal Academicians-a remarkable thing-such as Stanfield. For who could think now of the excellent Harker or Craven-a poetical artist-being enrolled ? Telbin's work particularly threw an air of reposeful refinement over the whole.

But words can hardly supply an idea of the degree to which the complete ruin of all dramatic or scenic effect is due to the extravagant overwhelming and blinding lighting of the stage. It has destroyed everything-colouring, distance, shadows, relief, etc.-and in practice actually interferes with what is spoken. Though the spectator's eyes are affected, still his ear and attention are also interfered with, as voices coming from out of glowing furnaces cannot have their full effect. The conditions are unnatural, and trouble us; nor can we accept the state of things as human. Every one lives, moves, and has his being in this blaze. Trees, walls, interiors all glow with flames. Contrast with this the very low key of light in use in our childish days, when there was no lime or electric light, only dull burning, unimproved gas. But what must it have been in the Garrick days, or even in Kemble, when the huge Drury Lane interiors that succeeded each other were found sufficiently lit under such conditions? One would have thought that threefourths of the huge stage must have been in darkness.

Mr. Gordon Craig has lately devised a new system of scenery, which seems a little bizarre. The spectator sees before him household screens and frameworks, on which are hung or draped pieces of coloured material, while shreds and patches of various textiles are fixed up here and there. There is a sort of general suggestion of the drawing-room. We are assured that it is quite a new departure, and that there is deep æsthetic 
meaning in it all. The theory, however, is scarcely intelligible, and too elementary, in its present stage at least. I can fancy the bewilderment and amusement of the regular carpenters, as they are called upon to change the scenes, and hang up in their places the various draperies and patches of colour. To deal with the matter theoretically, it may be said that the use of such homely stuffs for decoration is quite antagonistic to the regular conditions of the stage, as it is notorious that the strong light that plays upon them is fatal to all illusion, bringing out the very texture of the material, and never harmonizing with the painted portions. Every one will have noted how harsh and ungrateful is the combination of real curtains fixed up over a painted window, yet nothing is more common. The effect is really to betray the nature of the arrangement-that is, a pair of curtains clumsily and insecurely fixed to a surface of painted canvas. There is always the same discrepancy.

There is one element, however, in Mr. Gordon Craig's system which is excellent and in the true spirit of scenic illusion, and I naturally commend it because it is really the carrying-out of a principle that I have been contending for during a score of years, and which is insisted upon all through the present treatise. This is that it is a false and prosaic representation to bring on the entive of what is sought to be presented-i.e., a whole house, a whole square or street. This, it is shown, alters the scale of the human figure constantly, as the house may at one time be only a few feet higher than the figure, and at another 20 or 30 . So with a cathedral interior, which is compressed into a space of 30 or 40 feet square. Now, Mr. Gordon Craig meets the problem by only exhibiting a portion - that is, just so much of the real thing as would be seen in such a position, letting the imagination supply the rest beyond the lines of the proscenium.

$\mathrm{Mr}$. Craig's efforts are produced by the exclusion of all common details. Broad masses of colour, which really form a background to the figures instead of dwarfing them, a skilful distribution of light and shadow-these are his methods; it is impressionalism instead of realism. After seeing many of Mr. Gordon Craig's attempts-and he seems to have had a sort of carte blanche under Miss Terry's management at the Imperial Theatre-it seemed that the system had not much variety, and 
came back to the one effect-coloured lights, or something of the magic lantern. At first there was a little surprise, but as with the lantern, plus ça change, etc.

Recently he has issued a rather cryptic exposition of a later discovery of his, which he expects will revolutionize scenery. Some sketches of this new system were shown at a gallery in Baker Street. They were beautifully painted water-colour scenes. But I could make nothing of them. According to the printed explanation, the essence of the system is found in the applying of 'movement ' to the scene and its parts, and it is contended that as the performers and the action all move, so should the scenery. It may be, however, that the term is used in its artistic sense, as movement in an architectural façade. These things will be all explained by and by, when the author shall have developed his principles. But I doubt if much will come of it.

Mr. Craig's ideas are certainly artistic, but the serious objection is that they will be found monotonous-it will be the same effect in every scene. Thus one was struck with a cathedral interior in Much Ado About Nothing, a vast thing, impressive, full of an inspissated gloom. The effect was produced by folds of black drapery hanging vertically. There was no attempt at perspective; the pillars seemed to rise far, far above, until lost in the regions above the stage. It was as though one were standing right under a transept arch and were looking up. This was most effective at first, until we saw that these were deceptive draperies. In another scene there were more draperies and cushions. In other plays we had the same device, so it comes to this-that loose clothes, hung about more or less gracefully, have taken the place of canvas stretched upon screens. It will not do, I fear, for the improvement is not on the lines of principle. So long as we look through an arch at what is going on, you must retain the old false system, until the principle of a detached platform is recognized, the scene being the zone within which the group of performers move, until the whole is generalized. No reform is practicable. We must at least start from that principle-modify, compound, but adopt it as the base. The old system may be called the aquarian one, for we look at the actors much as we do at the fishes in the tanks. 


\section{CHAPTER VII \\ ' What IS THE SCENE?'}

$\mathrm{H}$

AVING pointed out so many objections and so many abuses in the existing system of representation, I may naturally be asked if these are absolutely insurmountable, and whether I am prepared to propose something by way of remedy. The answer is that the stage itself, and the modern ideas of the stage itself, the relation of the audience to the spectacle before it, are really founded on a false principle and a genuine corruption. The true principle was at work when the stage was inaugurated. I am not so absurd as to recommend the going back to these primeval conditions, but the tendency should be to recognize them as much as possible.

In this matter of the relation of scenery to the drama, I think we may come to one conclusion-that in principle at least each is more or less destructive of the other. If the one is overpoweringly assertive, the other perishes. They can hardly coexist. This, of course, is pushing the matter to the extreme. It is the eyes and ears versus the soul, and intellect. The combination of garish colours, dazzling blaze, and gaudy dresses, actually disturbs and distracts; and this abuse is wrought under the pretext of illusion. It is not going too far to say that on the stage is found less illusion than anywhere else; this may seem paradoxical, but it is really the truth. I would say that any unsophisticated person who saw a scene for the first time in his life would not recognize it for what it purported to be. He would make out a tree, or a small shanty, and a doll's house in the foreground, which he was told was the Squire's manor-house ; but he would shrewdly say, - These seem to me to be huge linen-screens with some painting on them.' There is the flood of yellow light always present 
by stage day and night. And yet these are the realms of fairy fancy and imagination. Blazing, dazzling light, gaudy colours, music, particoloured costumes, are all antagonistic to the appreciation of refined and exquisitely delicate allusions. They are, as it were, smothered in the confusion. In any case, the attention is distracted and the mind confused. Even comedies of a strictly orthodox type are now brought down to date and fitted with 'modern business.' As an illustration, I never shall forget one scene, and the painful disconcerting effect on the audience. A well-known American actress, highly popular, was 'starring' it in London, and she was to give Lady Teazle, a fine vehicle for her brilliant gifts. That admirable veteran Farran was specially engaged to support her as the one and only Sir Peter. A fine combination, it was thought, for the lady had a rare gift of comedy. Imagine his consternation when, after the Quarrel Scene, she rushed to the piano, gave a sort of show-off song, then, I think, a dance! But this was as nothing, for the whole was brought up, or brought down, to date by modern 'japes.' The text was interpolated with strange things. Never shall I forget the pitiable attitude of poor Sir Peter, who, incredibly mortified, had to wait while the lady went through this musical business.

To seek out the dramatic secret and its riveting fascination we must go back to the first elements. When we were children we all keenly enjoyed panoramas and dioramas, and legitimately so, for they stood on their own merits. These are now virtually extinct, and merely tolerated. But on the stage they flourish, acres of immaturely coloured canvases passing before us, all steeped in a sort of furnace blaze. Some of these things, we are told, have cost huge sums, but after the first glance of curiosity the whole scene of interest passes away in a moment. There is nothing dramatic, nothing of movement, in any painted or lighted things.

But turn to what is strictly dramatic-that most precious of things because most interesting. We find that from even its earliest, most elementary stages, it held all with a most absorbing interest. Two or three persons climbed up on a platform who had the power of reproducing some unusual exciting situation or character, and crowds gathered round to listen. It never failed. No one asked for large canvas screens 
painted over with trees and houses, and which you were enjoined to consider the same as real houses. They called up the scene as they listened, if they cared to do so; but the incident, the clash of character, was enough. We are always deeply interested in social episodes. They are truly entertaining, but, unluckily, they will not occur to order; it is only a rare accident that brings them about. In this case the dramatist and actor come to our aid and supplies these things ready made.

Yet on this arrangement hangs the whole correct philosophy of the drama; the very basis of true scenery is involved. With the modern system everything is seen as though we were looking into a peep-show. Pictures pass before us, figures pass before us, and all are within the lines of the arch. Under the older system the scene was in the open; the players were unconfined-they stood forth in the free air. The scene was somewhere beyond, but the action went on almost among the spectators. In short, the more general scenery is, the more illusive will be the effect ; the more particular and more mimetic scenery is, the less result may be looked for. This was fully recognized in the old theatres from Garrick's day down to Charles Kemble, when there were stock scenes and stock dresses. The system of stock scenery made everything very simple. There was an interior-either of palace, dwelling-house, or cottage-a street in England and abroad, a forest, a high road with trees. That was all. It would be possible, for instance, so to generalize the foreign street as to make it pass for either French, Italian, or German. The same principle was applied to the stock dresses, where a King of some centuries back was invariably arrayed in a crimson velvet coat trimmed with broad ermine, a velvet cap also thus trimmed. This was a conventional and accepted dress of every Shakespearean monarch. We could hardly recognize him in any other guise. There were stock Roman dresses, Old English, French and bandits'. As we know, Garrick in his early days went even farther than this, and generalized dresses off the stage altogether, every one appearing in dresses of private life, only of the handsomest pattern and material. Audiences did not require anything else, nor was the illusion impaired. I always look with interest at those modern reproductions of the antique 
stage, such as Palladio fashioned, and which was reproduced at Ammergau, and was structurally general. It was so contrived that it embodied or combined two conditions of scenery, outdoor and indoor. This, of course, was feasible under the Greek conditions of colonnades and courts, which were half in the open air and half covered.

But a more important principle still is involved in the answer to the question, 'What IS THE SCENE?'

In all the French dramas we find a scientific arrangement which supplies a hint for an answer. In most of these pieces there are innumerable scenes-often a dozen in an act. And yet the scene is not changed, for a new one is constituted by anyone leaving the stage or coming on the stage. There is significance in this, for it has nothing to do with canvas screens or 'built up structures.' The change is purely metaphysical.

I would answer the question thus: The scene is not the whole set enclosure, where there is an interior displayed; not a whole square, where there are a number of buildings; not the whole elevation of a castle at the back. I should call the scene the zone, or space round the performers engaged in the actionthat is to say, the same area that a person or group of persons would occupy in real life. This would amount to no more than a section. Suppose there is a drama in which a murder takes place in Trafalgar Square. To have this square suitably recognized the modern painter is compelled to introduce the church, the Gallery, the fountains-the whole, in short. These must be squeezed in somehow or anyhow. Now, in the case of a real scuffle taking place there, there would be only a fragment seen - that close to the parties concerned. Or suppose a man entering into a large chamber, where he is set upon and all but assassinated. He will not see or recall later the whole of the room ; he will only think of what was near him. He cannot say how many windows there were, whether there were two doors or one. In all situations of excitement no one can take heed of such matters.

In Garrick's time all the acting was in a central zone of this kind, four lamps being hung over it, the rest of the stage being in shadow, or 'haloed off,' as it were.

Nothing can exceed the falsity of the present system in regard to proportion. A castle with a gateway is shown on the stage 
-a regularly built-up structure, yet the arch of the gateway must be about a foot over the actor's head; but no one heeds. The castle itself, the 'peaceful vicarage' so often shown in comedies, cannot by any contrivance be more than, say, 30 feet high, yet this every one accepts. With a scene painted on a cloth you can have perspective, which reduces the size of everything without shocking; but within the zone that I have spoken of portions of these things can be exhibited.

That first urgent principle of the stage-i.e., a raised platform -strictly speaking, implies no scenery at all. The players create their own scenery, or appeal to the imagination of the spectators. They are there on a segment of Mother Earth, just raised sufficiently to put them in view of all. It is like two or three clever persons standing up in a drawing-room and reciting a passage from a play. If they are passionate and earnest we shall be so carried away that we shall not care for screens of canvas gaudily painted over and diffused with a blaze of dazzling lights.

As the perfect actor should present a general class of character, and not slavishly copy a single or special instance, so in the same way the scene should be a sort of generic place, as a church, a public place, a chamber in the castle, etc. And Shakespeare in many of his plays does not even condescend to give the scene a name at all, leaving the business of the scene itself to signify its locale to the reader.

It will be seen what an obvious inconvenience and inconsistency arises from the principle that the interior or exterior presented must be-laterally, at least-of the same size. The small cottage and the palatial hall, the vast square and the modest drawing-room in Mayfair, the market-place, with the cathedral and the vicarage garden, the towers, domes, etc., succeed each other, and the scale is constantly being altered. We have seen the whole of Charing Cross, with St. Martin's Church, Trafalgar Square and the lions, and the National Gallery, to say nothing of Morley's Hotel, all squeezed into the space which in the preceding or subsequent scene served to show a garret in the Borough. Yet mark this: The scale of the human figures that moved about in these surroundings remained, of course, the same, though the scale of the objects and buildings was constantly changing. Thus St. Martin's 
Church is about three times the height of the figures, and the walls of the garret-room about twice the height of the figuresall which absurdity arises from this literal imitation of external objects, and striving to bring the streets and houses on to the stage; whereas by a comparatively sceneless system, where the actors alone are the central objects, there can be none of these discrepancies. Any background should be always a constant quantity and of the same proportions.

To secure a genuine system of stage illusion we must look for scientific principles, to be worked out and applied, and not to be regulated, as things are now, by rule of thumb. We have started by answering the questions: "What is the stage?' 'What is the scene?' But 'What does the opening of the proscenium really mean ?' 'Where are the audience presumed to be in relation to the actors ?' are equally interesting queries. Answers being found for these questions, some first principles will be secured to work with.

To begin with the arrangement of the stage itself. There always seems an incongruity, and one that strikes the eyes, affecting even all dramatic propriety, when we see the heavy marble columns that support the arch resting upon the very boards of the stage itself. At His Majesty's Theatre we can even see the arch and its pillars of marble similarly appearing on the fore-stage. I say appearing, because we know full well that they are supported on substantial piers below. But if these marble columns were boldly treated-put forward prominently, reaching well down to the floor of the stalls, where they could assert themselves, while between them the wooden platform projects well forward-the effect or significance would be striking and dramatic, and quite a new idea would be conveyed to the audience.

From this arrangement we should see at once that there was a large arched opening broken in the wall of the theatre, and under this opening was a wooden platform, which projected in front of the arch, and on which the action of the play took place. In the older theatres there was always a great stretch of stage in front of the curtain-the undebatable land between audience and actors. This has been abolished, owing to the greed of profit and the necessity of finding yet more room for stalls. 
We may all the time fairly commiserate the daring managers who have to wear this tremendous and crushing Nessus shirt, so costly and so generally disastrous in result. Witness Macready, Charles Kean, and the piteous fate of Irving. What a contrast their state with the light, unencumbered situation of the comedy manager who is on the legitimate path, like Alexander, who may have, indeed, an expensive company, but is not pressed down by the weight of built-up scenes, rich and rare dresses, shows, and the rest. Neither has he the anxieties of a tired public and changing tastes. $\mathrm{He}$ is legitimate, and his legitimacy is generally new, fresh, and entertaining.

Disheartening as this review has been-for it has revealed an earthiness thoroughly un-Shakespearean-we still find a good deal of progress in public taste. The past few years have been record ones in the matter of revivals. Some eight or ten managers have been concerned - to wit, Beerbohm Tree, Oscar Asche, Otho Stuart, Forbes-Robertson, Lewis Waller, Benson, Martin Harvey, and Flanagan of Manchester. About twenty pieces were revived within two or three years-Othello, Hamlet, Romeo and Juliet, As Y'ou Like It, Measure for Measure, Much Ado About Nothing, Merchant of Venice, Antony and Cleopatra, Troilus and Cressida, Cymbeline, Henry V., Winter's Tale, Macbeth, Henry VI., Midsummer Night's Dream, Julius Cesar, The Tempest, Two Gentlemen of Verona, and Timon of Athens. 


\section{CHAPTER VIII}

ACTING, SOLILOQUIES, ASIDES, BY-PLAY, RECITATION, ETC.

$\mathrm{O}$ $\mathrm{NE}$ of the most interesting, and also important, of the questions connected with the revivals is this, How, under such trying circumstances, are the Shakespearean lines to be recited? What is to be the key or gamut? Should it be prosaic, familiar, and like everyday talk? or should there be highly artificial tones of sonorous dignity? Yet it is not difficult to find some certain guide that may help to decide the question.

I am afraid that it was our admired and venerated Irving who first introduced the abolition of the old stilted system of Shakespearean declamation. Why not, he thought, harmonize it with the general current of the time? Men talk to each other in a sort of unlicensed way; they do not declaim or preach. So when the young nobles of The Merchant of Venice, and Romeo and Juliet, and Much.Ado About Nothing came on the scene, how natural that they should talk like nobles and ' gentles' of our day! The familiar disregard of feet and measure would give, if not intelligibility, an everyday sound to the discourse.

Accordingly, Antonio and Bassanio chatted on, exactly like young fellows at Boodles' or White's, discarding all metre, pausing in the middle, and running the last portion into the first of the next line. Yet this sort of thing is quite out of keeping, and destroys the effect. It is disagreeable to hear the young noble 'gabbling' away for his bare life, rattling forth the precious stones of words in a reckless way, using noble words and phrases to rollicking accompaniment.

The antagonism between the stately phrases and periods, and such everyday sounds is almost comic. The young men speak so fast and so indistinctly, from lack of instruction, that the gold and silver words drop to the ground and are lost. It is really 
as though the noble lines are uttered to a sort of banjo accompaniment. We might conceive of some up-to-date clergyman-and we have often heard such-thinking to better realize the situations for his hearers by reading the Holy Scriptures in the key of everyday life, with familiar inflections and airy tones. The effect is grotesque, and in a sense shocking. At every instant the solemn words protest against such levity.

It is so with these great lines of Shakespeare. There must be elevation-a certain state and solemnity-and music also. But with the reign of this modern prattle, as it may be called, arises a more serious thing. A few words of the barda line or two-are so suggestive, so packed with meaning, that it takes thought and emphasis to bring it out. Further, there are words used in recondite or archaic senses, forms of phrase that belong to the past. These being chattered forth at an express pace are almost incomprehensible-nay, from defective elocution, they are scarcely heard even. The lines should, indeed, be delivered, not recited-that is, the meaning should be first sought for, and brought to the surface by deep thought and reflection. It is forgotten, too, that there is a subsidiary music in the words, which it is a delightful thing to listen to if properly uttered. This we know from the stock passages-so certain of applause-which are licensed, as it were, to be delivered in correct fashion. At the Théâtre Français how delightful the entertainment of listening to that rather monotonous, even dreary, piece Le Misanthrope, from the exquisitely melodious declamation, carried on through long, interminable speeches, yet all lit up and made intelligible by the emphasis and cadences of the player.

And yet I believe this talkative method is accepted generally, and even admired, as being 'so perfectly natural.'

Some generations ago, when stalls were rather a novelty, there was found in all the theatres a sort of advanced stage, that projected some 30 feet or more in front of the curtain. This used to be known as 'the apron,' and was really an extra stage in the auditorium. On this the singers and actors declaimed their parts. By and by, as the stalls grew in favour, it occurred to many that here was so much space wasted. A portion was sliced off and rows of stalls substituted. Gradually the whole 
projection was abolished, and now a plumb-line dropped from the crown of the arch would almost fall straight to the bottom of the orchestra.

This may seem a trifling matter of arrangement, but it really involves a vast and radical principle, for this apron really suggested the true original form of the stage-that is, of a raised platform round which the audience was grouped. It showed this platform projected through the arch, and thus destroyed the notion of being a picture with a background, or any enclosure into which an audience looked. During the performance the actors could not help coming far forward, actually into the body of the house, with great advantage to their efforts; and at these moments they were exactly in the condition of the primitive actors, and independent of all scenery. It is extraordinary what an air of truth and reality this imparted.

At the present nothing can be more mean or stunted than the effect of the truncated stage ; there was such an abstract air of flowing space, even when the curtain was down. We felt that here was the actor's land-the earth, as it were, on which he stood and walked.

It seems but a trite and hackneyed thing-it is so constantly done-to talk of the superiority of the French and other foreign acting ; but what is not thought of is that it is the real acting, while ours is another thing altogether and on different lines. The English actor, given a character, recites his part; he treats it objectively; he gives it emphasis, and simulates the different emotions as best he can, but all the time it is objective. He still remains $\mathrm{Mr}$. - who is representing the part $\mathrm{X}$. The functions are distinct. The public foster the notion by 'going to see Mr. _ ' rather than the character he plays. Mr. _ always remains Mr. - ; it is the system. The French actor, with his imagination and dramatic feeling, cannot help casting his own skin and becoming lost in the character. He acts it; he becomes it for the time. Hence the interest, the enjoyment with which we follow him. His words are not recited; they come from him naturally, as if unthought, to the moment. His bearing, gestures, expression of face, is all acting also. With our people we rarely for a single moment, even in the case of leaders, take them for the characters: they are performers. This permeates every department. The scenery, dresses, etc., 
are all so many exhibitions, without any homogeneousness or relation to the acting. In the Shakespearean revival this showman element is more conspicuous than in anything else. Each scene is an exaggerated farce, or show, claiming praise, and this system of objective recitation, as I have called it, is pushed to the furthest. I venture to say that to repeat a single speech of the bard's with heart, feeling, nature, emphasis, is a result that could only be obtained by a refined and diligent education pursued for years ; there should be colour, restraint, reserve, and a dozen other things. Then the long series of lines becomes lighted up, as it were, and intelligible, and of absorbing interest for the spectator.

Another cause of this failing in English acting is perhaps the national character, which is plain, straightforward, and literal. It likes to have all in black and white. But in social life nothing is in plain black and white: everything is shaded off. Few British actors understand the 'double intention,' for instance ; to say a complimentary thing and at the same moment convey contempt or derision. This, however, can be done. Nor do they, while seeming hard or cruel, know how to show that underneath they still love and cherish. These delicacies require a sort of inspiration. What of letting the angry glance or troubled gesture precede the utterance and convey its meaning ? What of the impetuous glance, so significant that it tells what is presently spoken in words? There are plenty of welltrained, well-cultivated actors, but few that act, in this sensethat really act-that is, act with their glances, body, movements, before saying a word.

The Americans really act, particularly the actresses. They put nature into the characters. We have seen American actresses quite equal to the French. In a recent piece by $\mathrm{Mr}$. Henry A. Jones it was extraordinary to note the contrast between the free, spontaneous nature of the American who did the heroine and the wooden, cramped, and artificial treatment of her companion, who did a managing mother.

When a marked or eccentric character is allotted to a player, he has but the one way-follow the established tradition. Thus, in a recently performed play there was an odd stolid Baronet - meant to be sententious, intrusive, and meddling, canting also. His family also intruded and canted. Every time 
he uttered a sentence he seemed to prelude it by saying, 'Mark ye, now I am going to cant.' And so, with an affected, stagey voice and solemn gestures, he went on with his preaching. You felt it was unreal. No one that cants gives notice that he is going to cant in this way. Canting folk can be as natural as common folk. They don't use a sing-song voice. Intruding folk disguise their intrusions. But no; it is thought unless your acting is properly labelled and perpetually announced to the audience, it will not be effective.

What is wanting in acting-not only in acting merely, but everywhere-is the precious gift of distinction. It is a most difficult thing to define, but we can always feel its presence. Distinction, I might say, is the complete ignoring-or disdain, even - of common methods and agencies. The soul is so completely absorbed that it can give no thought to the accepted modes of expression, so often confounded with the thing to be expressed-as in painting, when the commonplace artist thinks chiefly of his model and its draping, the methods of drawing, colouring; or as in writing, when the writer thinks of his periods of word-painting. On the stage the artist will permeate himself with the character he plays ; he will not heed ' make-up' or dress or attitudes. The one and only thing before him is character - the mind, in short : that mind which to him literally 'a kingdom is.' This is felt particularly in Shakespearean creations. We see this in daily life, where a man takes no thought of the meaner and more earthy elements. He views all things with his high soul, disdaining to impute motives or to employ shifts or devices. The dress, even of a man of distinction, instinctively reflects his character; it is not rich or handsome, but proper and correct, not attracting the eye at all.

Some of the old players had great distinction. Irving particularly was a man of distinction. In most Shakespearean revivals it is generally lacking, and this of studied, set purpose, for the aim is to present the piece in as modern a fashion as possible. Thus Malvolio has been studiously stripped of all distinction. He is to be taken literally and practically and as selfconscious. The real steward was one absorbed in dreams, and so indifferent and superior to all vulgar incidents that he would never have had four retainers walking before him-to a tune. 
Distinction also means the unconscious revealing of changing feelings and emotions which the man of distinction disdains to conceal. He allows his contending feelings to be seen. Modern acting allows of but one inflexible form of character, not to be changed. A man is haughty or hypocritical; he must continue so to the end. But in true acting inconsistencies are shown.

I can quite understand the performer saying to herself in the case of Rosalind or Celia : 'Now I have to do some rustic folk. I have been in the country, and I remember well their ways, which I must reproduce.' There is a sort of tradition for these things-a kind of rough style and manner. Or here are two young girls out for Bank Holiday, most obstreperous creatures -all this is before the mind of our actor or actress.

It is astonishing and little known or thought of, how the power of elocution, with attendant gesture or bearing, will supply the place of the most elaborate scenery and produce the most convincing effects. It is possible, by this feeling of conviction, to persuade others that something is present that is really not present; the very tones and bearing persuade the spectator more effectively than the most elaborate mechanical effort. Such is the purpose of acting. Instead, the modern system is to appeal to the eye instead of the heart and feeling. In real life, when we see two men together speaking with the utmost courtesy and apparent friendliness, a shrewd observer may say: "Those two hate each other!' There is something in their bearing, the tone of the voice, the glance of the eye which reveals it. But our modern actor has but the one way to exhibit his hate: by a scowl, a scorn in his voice, a gesture of contempt; better still by an aside given him by the author, in which he will say boldly that he hates, so that there can be no mistake about it. In fact, without this palpable evidence of his feelings, he can do little.

The departments of acting, outside speech, are indeed innumerable. Who thinks now of facial acting? for its power is quite lost, owing, I really believe, to the floods of light, which overpower all shadows and lines. Let us recall Elia's recollections of Dodd :

'In expressive slowness of apprehension this aćtor surpassed all others. You could see the first dawn of an idea stealing slowly over his conscience, climbing up little by little, which is 
a painful process, till it is cleared up at last to the fullness of a twilight conception. He seemed to keep back his intellect. A glimmer of understanding would appear in a corner of his eye, and, for lack of fuel, go out again. A part of his forehead would catch a little intelligence, and be a long time in communicating to the remainder.'

I can fancy the amusement-nay, bewilderment-of some of our journeymen as their eyes fall on this. 'What! do all this with your face? Oh, go to!' All this seems a lost, incomprehensible art-beyond histrionic power. In this connexion we think of the false face when we hear an actor praised for his powers of 'making up,' as it is called ; it leaves an uncomfortable feeling. We know that it is base mechanical operation, and opposed to the principles of acting. One that alters his face in this fashion interposes a regular mask between him and his hearers. Expression becomes impossible. The effect, if a surprise, does not last a minute. No; your true actor will make up, as far as possible, from within. With an intense power of realization, he will force his features to correspond to what is within him.

How conventionally, too, is represented some oddity of speech and manner provided by the author. Is it not invariably mere repetition, brought in always after the same fashion? And yet it is obvious that there are varied methods which can be applied, so as to suggest spontaneousness. The player may catch or check himself; he may say it unconsciously. But, after all, it is a difficulty, though never great, as it is so unnatural, for no eccentric brings in his catchword in every sentence.

Listening, after all, is acting, and a very important department. It properly belongs to the utterance of a person who is speaking, who, if he sees attention and understanding and interest in his listener, is compelled, as it were, to give more point and emphasis to what he is saying. The two faces and voices make one whole. But a sort of smiling indifference is the usual display. The listener really shows that he is only waiting till the other has done. One who is listening to a story or explanation will show a mixture of emotions-now surprise, now dissent, now agitation, now great interest, etc. But these things are overlooked. This traditional indifference or detachment is a sad blemish of the silent partner in a dialogue. He appears to 
be waiting patiently till his turn comes round to speak. Our more intelligent actors, indeed, affect a sort of stagey interest, smiling or nodding, etc.; but this is not nearly sufficient. They should be as interested and absorbed as the speaker, reflect his mood and emotions, show an eagerness to interrupt, and check themselves, turn away impatiently, in short, be one with the speaker. In lovers' scenes, too, we have too often the same stilted method of alternate speeches. It may be said, in fact, that the listener is just as important and should act as much and as forcibly as the person who is speaking.

The boisterous stage laugh is familiar enough, but it is quite unlike any form of merriment heard in the world outside. It is forced and unnatural-an emission of artificial ' $\mathrm{Ha}$ ! ha's!' in a series, solemnly done and with machine-like regularity. It never produces that contagious responsive return from the listener which genuine merriment always does. And yet it is a great, most important, element in the art of acting. It has its preparatory stage in a growing sense of amusement, the consciousness of something ridiculous approaching, the struggle to restrain it from politeness, the restraint at last giving way as the thing became too absurd, with the final enjoyable burst of hilarity. How infectious all this, as we see it on the French stage! Its incomparable players do not need to utter ' $\mathrm{Ha}$ ! ha!' as the visible, necessary sign of enjoyment. You read the feeling of amusement in the faces, the eyes, the pursed lips. It is as though they were saying to us: "This poor foolish man is quite too much for us. What a goose he is making of himself!' And this sort of facial acting compels us to believe that the man is a goose, and that without any effort of his own.

And what a whole gamut there is of laughter!-the contemptuous, the forced, the loud and vulgar burst, the sarcastic, the bitter, the titter. When a number of persons are enjoying a hearty laugh together it is extraordinary to see the varieties, the different methods of enjoyment. And here, it may be said, our players wholly forget that every speech or remark is certain to affect the listeners in some fashion or other-that is, if they are interested. There is eagerness to answer, protest, dissent, cordial approbation, contempt, etc. This should be exhibited, to give point to the speech. But, as I have said, they usually 
think of their own spoken answer that is to come, and so wait until their companion has done. I repeat, three-fourths of genuine acting is found in the expression of the eyes, face, figure; in the unspoken utterances of gesture and movements of the figure; in the anticipation of the coming speech by a significant movement of the arm, which works faster than the voice, and, owing to emotion, cannot wait. Who thinks of these things-considered, no doubt, as trivialities? Who thinks that in moments of agitation the words are propelled forth rapidly in a torrent, jostling each other, as it were ? Yet Irving, odd to say, always grew slower and yet slower at such tempestuous passages.*

Personages of high rank, with their entourage, are now, in modern comedies of manners, often placed on the stage. We could mention some West End houses where whole bevies of fine ladies, Countesses and others, moved about the salons. It was extraordinary what an exhibition of polite manners and bearing it was. The type aimed at seemed to be some of the high-class opulent trading folk, who entertained them, and whose superior style they thought it safest to copy. But who could expect these actresses to learn the ways, sayings, and doings of such lofty dames? How were they to do it? Well, it may seem 'fantastical,' as Elia has it, but it really can be done, or nearly approached, by thought and that visualization I have before spoken of. There is the native instinct of gentility, founded on a sense of propriety and on what is becoming, which is common to all ranks. There is the taste for superior reading and superior models. An assumption that these Countesses will behave naturally and in a lady-like, becoming fashion, will beget of itself a suitable conception. But no. There is the vulgar theory that overbearing manners, with ludicrously haughty speeches, are true notes of high rank.

Hesitation, difficulty of deciding between two courses-it really requires the greatest skill to express such emotions.

* In that very sparkling comic opera The Merry Widow there is an admirable American player, Coyne, who is determined to resist the advances of the enchantress, but is again and again led on by her seduction to the verge of confession, when of a sudden he recollects the danger and breaks away in a sort of grotesque fury with himself and her, only presently to fall into the trap once more. Nothing more diverting or more in spirit of comedy has been seen of late. 
Yet it is quite possible to exhibit fearful agonies of hesitation and uncertainty without any particular exertion. How often do we hear in private life, 'I see you have something on your mind.' The person in question has made no show or exhibition, but somehow he betrays his feeling. Our English player, a downright, strenuous fellow, cuts the knot. 'What shall I do ?' he says, in his blunt way: 'shall I marry her, or shall I not ? After a moment he renders it Yea or Nay, and so settles the business. But if acted, how protracted! what uncertainties, difficulties, agonies! 'What is to be done?' Walking, striding up and down, is a safety-valve for agitation. To keep in motion relieves tension. Yet when unacceptable advice is given, it is often received with a stony stare and in silence. I doubt if all these things are to be learnt by diligent observation; they come rather by instinct, if the performer 'lets himself go' and 'yields to the influence.

The charm of acting really depends on the crossing and intermingling of all these currents of emotion and feeling; study and practice, and also genius, will help to distinguish them. Acting is not, as is thought, a downright statement, but a complicated pattern of many shades and colours delicately interwoven. Everything is double and treble. There are submeanings, as when the fair one says 'No,' but the lover reads it 'Yes.' I really believe that such uncertainties make up the charm of acting.

In life we often come across amusing characters, but it is rarely that they exhibit, because opportunities are not furnished. The most fitting display arises, it may be, out of an accident, and such accidents cannot be ordered in advance. The true dramatist, however, by his peculiar craft, can supply these situations. He has studied human nature; he knows the works as the clock-maker does his clocks. He does not mistake smart dialogue for character, and he knows that it is only action that can exhibit character properly.

But the common young man who has seen in real life what he takes to be an amusing character will proceed literally to copy the traits instead of recreating and generalizing. He stands in need of earthy illustrations, and cannot do without the same recurring jests, peculiarities of manner, oddities, grimacings, and, above all, make-up. 
The delight furnished by all the arts is founded on abstraction and selection. Thus, on a rare occasion we note a tender melancholy in some evening landscape. A Corot comes by, notes and reproduces it. A sweet face shows some delicate expression, half smiling, half sorrowful, wholly innocent, and Greuze has caught it. The poet puts into words lovely thoughts which no one else could express, though mistily conscious of their existence. Characters, stories, actions, may be described with accurate and literal truth, and yet seem uninteresting and unmeaning, until one who has the key unlocks the secret chambers, and all becomes spiritualized.

Few have noticed the complete extinction on the stage of the old low comedy characters. Such parts are rarely found in modern plays, and the actors who gave them effect are not in demand. The traditions, therefore, are being lost. No one now can cause prolonged laughter by his mere look, air, and bearing. I recall, at the old Haymarket, when the first note of Buckstone's cheerful voice, heard behind the scenes, produced a roar. Naturally, therefore, the broadly humorous character of Shakespeare cannot be interpreted with the breadth and weight that are necessary. There is a class of character, such as Pistol, Nym, Autolycus, Bardolph, and many more, who are often in places almost unintelligible to the average unthoughtful or uneducated mind. If we were to set an actor to recite, say, some of Pistol's talk to us, he would find it difficult to bring out the bare meaning of most of the sentences ; it would seem to him a sort of antiquated jargon. There is so much that is elliptical and buried in each word or sentence, that it would take a skilled commentator long to make it all clear, and then would come the more difficult task of the delivery. There should be a certain breadth, a sort of high reserve, an air of unconsciousness, as though the whole was a natural form of speech, absolutely necessary, and a sort of pawkiness too. Mr. Asche possesses this breadth of tone and power of significance. They are all characters. And let an average English actor try and render the inimitable Bailie Nicol Jarvie : he will find it as difficult as that of Pistol. What, then, is the performer to do? Nothing, save fall back on the usual stage formulas and work on his own lines. Pistol is a braggart and coward, so he must stride about and flourish, roar and cringe in a broad, intelligible way. That old friend 
the grave-digger in Hamlet is still invariably overdone in this fashion; though happily the series of waistcoats has been abolished, it is still seized upon as a precious opening for low, exaggerated treatment. Who thinks that the fellow was a perfect philosopher, engrossed with his craft ?

That grotesque and entertaining group has rarely been presented with such effect as in Mr. Waller's spirited revival of Henry $V$. To the average actor their lines seem scarcely intelligible; they seem to belong to a recondite style of humour, to the secret of which he cannot pierce. The only resource is to fill it out with the comic man's methods, and force the jocosities to take a modern shape. Undue stress and emphasis are plentifully employed. Pistol becomes a sort of swaggering blusterer; but in Mr. Mollison's hands what a quaint, fantastical character it was! The fellow is striving to carry off his cowardice by a sort of poetical exaggeration, a quixotic air; he imposes on us to a certain extent, and almost excites a sort of interest by his highfalutin flights. He believes in himself, and his friends seem to believe in him too; he is so convincing. Bardolph, too-natural without undue emphasis or labouring after fun. His archaic phrases-' the humour of it,' etc.-are only his method of expression, and we understand him perfectly.

How rarely do we hear ' a soliloquy,' as it is called, delivered in a natural or convincing way! It is almost invariably intended for the audience-a sort of address to the public. A soliloquy represents the irrepressible current of thoughts passing through the mind, without order, or sometimes without coherence. All sorts of possible and impossible things suggest themselves and pass away; nothing is clearly formulated, though at times something impresses the dreamer more than the rest. The speaker should therefore seem quite unconscious of the world without, even of the words he is uttering or allowing to escape him. Movements of passion, vehemence, and impatience there should be, for in these we most naturally indulge, even in our private council chambers. One could almost imagine Hamlet addressing some imaginary companion-his own double, it might be-as he wanders on from topic to topic. The position of the audience is that of an eavesdropper. Such a principle would make the soliloquy quite a different thing from what it is 
now. How stagey and artificial, therefore, is the accepted notion that the speaker is sitting down to have a good long talk with himself, the stage being cleared for the purpose, the truth being that while in company his mind was full of the topics, and when alone these began to escape him, being discharged to relieve himself as he moved about restlessly.

The aside, so largely used in the old dramas, was a method of letting the audience know the real or secret meaning of the speaker, as when some sort of Iago was assuring his victim of his fidelity, he turns away, and will allow some expression of hate to escape him. This is untrue to nature, for even the professional villain or hypocrite is not inclined to reveal, even to himself, his turpitude. The aside should be acted, not spoken. How absurd are these announcements : 'Now I will probe him to the quick'; 'How he tortures me! But be still, my heart'! But there are occasions when the aside becomes natural enough, as when impatience at some display of absurdity causes a half-muttered exclamation, such as: "Was there ever such a goose!' 'D—d fool!' 'I can't endure this much longer!' 'What next, I wonder!' These are true asides, and, properly developed, add to the dramatic force of the situation.

Hamlet is, of course, the great répertoire of soliloquies. The aspiring actor about to adventure on the Dane at once bethinks how he is to treat these meditations. The accepted method is to make each a detached performance, with a crescendo movement, working all up to a finish-all which is artificial, and not consistent with the dramatic business of the play. Instead of being detached, it should be a part of the action.

Let us take the familiar ' Oh that this too, too solid flesh would melt!' We all know how this is handled. So soon as the stage is cleared of the King, the Prince sinks into his chair, and, after due pause, begins, then travels through the long speech. But what is the situation? He is disgusted at his uncle's hypocrisy, his public lecture on indulging in grief; he is fretted at the constraint on himself, and then breaks out: ' Oh, how long is all this to go on? Would that I were dead! Only that self-destruction is wicked,' etc. A man in this state of agitation does not go prosing on at funeral pace; his words are poured forth quickly and even furiously. All this is natural and dramatic. If this natural view were adopted, we can see 
after what a different complexion should be Hamlet's soliloquies, which every player gives for 'all that he is worth.' Let us take another well-known example. He has been listening to the recitations of the players, who had given their tragic scene with much emotion, and as they leave him it strikes him as strange and humiliating that these hired creatures should exhibit such realistic grief, while $h e$, with his monstrous wrongs, could look on calmly and wait. Was he a coward ? he asked. Then the idea of the play took shape as a first step. That is the pith of the fifty-seven lines. Yet what an elaborate business our actors make of it! -always so slow and momentous and deliberate that we almost overlook the connexion of thoughts. Yet we could fancy Hamlet, after they had gone, dreaming over the 'mobled Queen' and the tears, and then breaking out: ' Oh, what a wretched creature I am! Oh, what a peasant slave am I!' Yet in this ruminant key should the whole be delivered, with numerous pauses for meditation, getting up, sitting down, and new suggestions. This would happen in real life, and we could well imagine so highly-strung a being talking to himself or acting aloud. Instead he prepares slowly for the coming soliloquy - a detached effort, a speech, in fact.

The great actors have ever striven to make something original out of Macbeth's 'Is this a dagger?' and we are warned that it is at hand. It is nearly always spoken slowly and deliberately, the eyes fixed on vacancy. And yet if one saw a spectral dagger, would there not be a sudden start, with drawing back, rubbing of the eyes, and hurried, agitated words ? Our players never think that the more excited the situation, the faster should be the utterance. Then do the words come forth pell-mell, as it were. Sir Henry Irving adopted the opposite course, and got slower and yet slower as he became agitated.

The instruction to the players in Hamlet offers a fine opportunity, and is invariably magnified and made the most of. Yet how easily can we understand what should be the proper tone! A young nobleman is giving his actors a few hints before the play begins: 'Now I do conjure you,' he would say-' no vulgarity; this is a private house. Give it all lightly and with animation. Don't put in anything of your own"gags," and such things. It really makes one sick to hear the 
stuff actors introduce; it only shocks the intelligent part of the audience,' etc.-all this spoken earnestly and naturally. Instead, we are given a lecture on elocution.

So with Richard III.'s famous utterances, 'Now is the winter,' etc., where 'glorious summer' made triumphant is illustrated by a chuckle; while 'In the deep bosom of the ocean buried ' is gloomy and menacing, especially when it is so often given with a pause ('the ocean-buried'), the reciter pointing downwards, as though the ocean were there. It is, in fact, an elaborate recitation, to be made the most of. And yet it should be nothing of the kind. It is a rumination in which the wicked Duke turns over his situation, plans, tries this and that, and allows his thoughts to wander from topic to topic. In this view we cannot fancy him striding down to the front and announcing to the audience that the 'winter of his discontent' has been made 'glorious summer.' He would enter irresolutely, absorbed in deep thought, pacing to and fro, without speaking. The difficulties of his position, his plots and plans, are before him. Then he suddenly stops, and it occurs to him that, after all, his prospects are really favourable; for 'Now is the winter of our discontent made glorious summer.' All the others are engaged in amusements, love-making, etc. And then it occurs to him, after a pause-all save his own ill-fashioned self. $\mathrm{He}$ was not made for that sort of thing-he, a poor deformed creature. Still there was compensation. He was determined to prove a villain, and carry out all his schemes, etc.

Now, here is an intellectual process going on, but not a speech or oration to the audience. He was really drifted along in an uncertain way from one scheme or thought to another. $\mathrm{He}$ works out in the hearing of the audience what he will next do. But all the time he is communing with himself. Of course this will not do for the Waldengarvers of the stage, who must have their roarings and scowlings, and inform the audience that they are villains.

It may be that these criticisms on the prevailing methods of English acting will be considered harsh and even illiberal. But I have been speaking of a long-established system, and not of individual performers, who are as intelligent and skilful as any in the world. The defects noted are due to their situation and surroundings. How can brilliant conceptions, delicate 
shades of character, refined utterances, struggle against the burden of their gross surroundings, 'built up' structures, crowded furnishing, bewildering light, crowds, dresses, etc. ? They are crushed, overpowered, and have to resort to quite a new service of arts to make even their presence felt.

In some West End theatres, where the players come forward to treat the unencumbered drama, we find intelligence, vivacity, dramatic feeling, and other attractive gifts to excite our interest; but this we hardly look for under the cabining and confining influences of the panoramic methods. 


1, $\quad \ldots$ 
